\title{
WestVirginiaUniversity
}

THE RESEARCH REPOSITORY @ WVU

Graduate Theses, Dissertations, and Problem Reports

2017

\section{Costuming "The Trojan Women", Produced at West Virginia University}

Cody K. Lorich

Follow this and additional works at: https://researchrepository.wvu.edu/etd

\section{Recommended Citation}

Lorich, Cody K., "Costuming "The Trojan Women", Produced at West Virginia University" (2017). Graduate Theses, Dissertations, and Problem Reports. 6111.

https://researchrepository.wvu.edu/etd/6111

This Thesis is protected by copyright and/or related rights. It has been brought to you by the The Research Repository @ WVU with permission from the rights-holder(s). You are free to use this Thesis in any way that is permitted by the copyright and related rights legislation that applies to your use. For other uses you must obtain permission from the rights-holder(s) directly, unless additional rights are indicated by a Creative Commons license in the record and/ or on the work itself. This Thesis has been accepted for inclusion in WVU Graduate Theses, Dissertations, and Problem Reports collection by an authorized administrator of The Research Repository @ WVU. For more information, please contact researchrepository@mail.wvu.edu. 


\title{
Costuming The Trojan Women, produced at West Virginia University
}

\author{
Cody K. Lorich \\ Thesis submitted to the \\ College of Creative Arts \\ at West Virginia University \\ In partial fulfillment of the requirements for the degree of \\ Master of Fine Arts in \\ Design and Technical Theater: Costume Design and Technology
}

\author{
Mary McClung, M.F.A., Chair \\ Alan McEwen, M.F.A. \\ Tiffany Delligatti, M.F.A. \\ Dr. Jay Malarcher, Ph.D.
}

WVU School of Theater \& Dance

Morgantown, West Virginia

2017

Keywords: Costume Design, Theater, Greek Tragedy, Euripides, Trojan Women, Gwendolyn MacEwen

Copyright 2017 Cody K. Lorich 


\section{ABSTRACT \\ Costuming The Trojan Women, produced at West Virginia University.}

\section{Cody K. Lorich}

This thesis describes the development of the design from the initial reaction to the script, meetings with the director and other designers, research, execution and final evaluation for West Virginia University School of Theatre \& Dance's production of The Trojan Women. Additional support includes sketches, research images, renderings, paperwork and production photos.

Euripides' The Trojan Women adapted by Gwendolyn MacEwen depicts a moment in the lives of victims of the Trojan War. This version of the Greek Tragedy utilizes contemporary poetic language paired with a stylized design approach.

From the start, the director intended for this production to be stylized. That is, instead of realistic bruised and tattered women, he wanted to convey some sense of beauty through the telling of this horrific story. The costumes, scenery, and lighting needed to be stunning while still supporting the tragic storyline. Everything would look as poetic as the words sounded.

Creating a look that would feel timeless meant finding a balance between Greek and contemporary clothing. The research for this production had a wide span; I used ancient artifacts, modern refugee women and art as inspiration for the costumes.

After the approval of final designs, my responsibility shifted to overseeing the build process in the costume shop. After designs were discussed and budgeted, I then moved forward in organizing paperwork, purchasing and organizing fittings. Though the costume shop worked smoothly with only a few minor setbacks, everything was finished properly and on time.

Throughout this process I learned the importance of troubleshooting and how to better express my opinions when issues arise. These are lessons I will continue to apply as I move forward in my career. 


\section{ACKNOWLEDGEMENTS}

Thank you to my family for supporting my love of theatre since day one. Thank you Mom and Dad for encouraging me to pursue my dreams even when I felt they were out of reach. I am so grateful for you every single day.

Thank you my Borg, Lauren and Cece. I am so glad to have you by my side. I could not have made it though grad school without the two of you. I love you sew much!

I would also like to thank my thesis committee for their advice and encouragement throughout this process.

\section{$\underline{\text { A Thesis Haiku }}$}

No no no no no

I do not want to write you

Is it over yet? 


\section{TABLE OF CONTENTS}

Abstract..$\ldots \ldots \ldots \ldots \ldots \ldots \ldots \ldots \ldots \ldots \ldots \ldots \ldots \ldots \ldots \ldots$ ii

Acknowledgements $\ldots \ldots \ldots \ldots \ldots \ldots \ldots \ldots \ldots \ldots \ldots \ldots \ldots \ldots$ iii

Table of Contents. ............................... iv

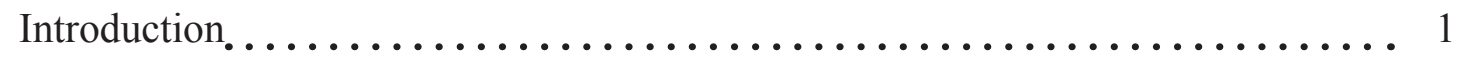

Plot Summary. ................................. 3

Design Process and oncept .......................... 9

Research .................................... 12

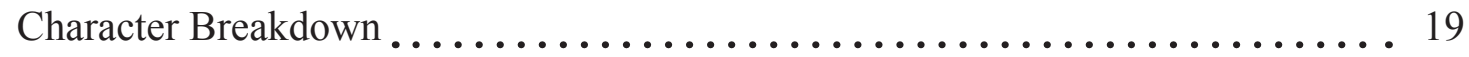

Production Process ............................... 44

Organization............................... 44

Build Process ............................. 47

Communication........................... 51

Execution of Performances $\ldots \ldots \ldots \ldots \ldots \ldots \ldots \ldots \ldots \ldots \ldots \ldots \ldots \ldots \ldots \ldots$

Dress Rehearsals ........................... 53

Run of Production .......................... 56

Production Outcome .......................... 55

Conclusion.................................. 59

Learning Outcomes .............................. 59

Appendices.................................. 61

Appendix I: Research Plates ........................ 61

Appendix II: Image Sources for Research Plates. . . . . . . . . . . . . 70

Appendix III: Rendering and Production Photos ............... 76

Appendix IV: Production Calendar. .................... 96

Appendix V: Production Spending. .................... 98

Appendix VI: Initial Budget and Piece List. . . . . . . . . . . . . . . . . . . 100

Appendix VII: Sample of Daily Report. . . . . . . . . . . . . . . . . . . . . . . . . . 104

Works Cited .................................. 107

Image Sources................................ 108 


\section{INTRODUCTION}

Euripides' The Trojan Women, adapted by Gwendolyn MacEwen was performed in the Gladys G. Davis Theater at West Virginia University as part of the School of Theatre \& Dance fall 2016 season. Dr. Jay Malarcher directed this production, with lighting design by Professor Alan McEwen, scene design by graduate student James Raymond, and sound design by undergraduate student Ricky Moats. Professor Steven Neuenschwander served as Production Manager. Byron Utley served as Technical Director, and Rebecca Smith as the Stage Manager, both undergraduate students. Professor Tiffany Delligatti served as Cutter/Draper, and graduate student Lauren Brennan served as both Wig Master and Crafts Artisan.

The director searched through several translations to select the best version for this

audience. Word for word translations can feel disjointed and lack the poetic aesthetic that would have been expressed in the original Greek. In my experience, contemporary audiences can feel disconnected when watching ancient Greek plays due to the style of language and lack of familiarity with Greek archetypes. MacEwen utilized contemporary language and left out ancient references that audiences may not comprehend. For example Euripides references the little known battle of Salamis, Alcmena, the mother of Hercules and King Telamon, the father of Ajax.

MacEwen is considered one of the top Canadian poets; her background allowed her to create a style that flowed smoothly while being accessible. Dr. Malarcher also felt it was important to find a translation by a woman since there were no other female authors represented in the WVU theater season. A show so focused on the emotional battles of women benefits from 
female perspective.

This version of The Trojan Women places focus on the women who are left when the war is over. Euripides' original play devotes significantly more time mourning the city itself, not the women. There is a strong emphasis on the psychological battle the women go through as they realize all they have lost. Through these women MacEwen shows examples of stereotypes women have endured for generations; Cassandra, the young virgin, Andromache, the wife and mother, Hecuba the old widow, and Helen the beauty and slut. Her version depicts a story about Trojan women of long ago and relates them to women of any era. 


\section{PLOT SUMMARY}

The Trojan Women opens on the beaches of the fallen city of Troy. Poseidon explains that the great city of Troy, the city he built, has fallen. Troy was a perfect society; all the men and women did just as they were supposed to and worshiped the proper gods in the proper ways. The city that was once holy now is covered in blood after suffering ten years of destruction brought to them by the Greeks. Poseidon continues to narrate as a group of women are pushed on stage. He explains that these are the women of Troy who have been brought here to wait as the Greek men cast lots to win them.

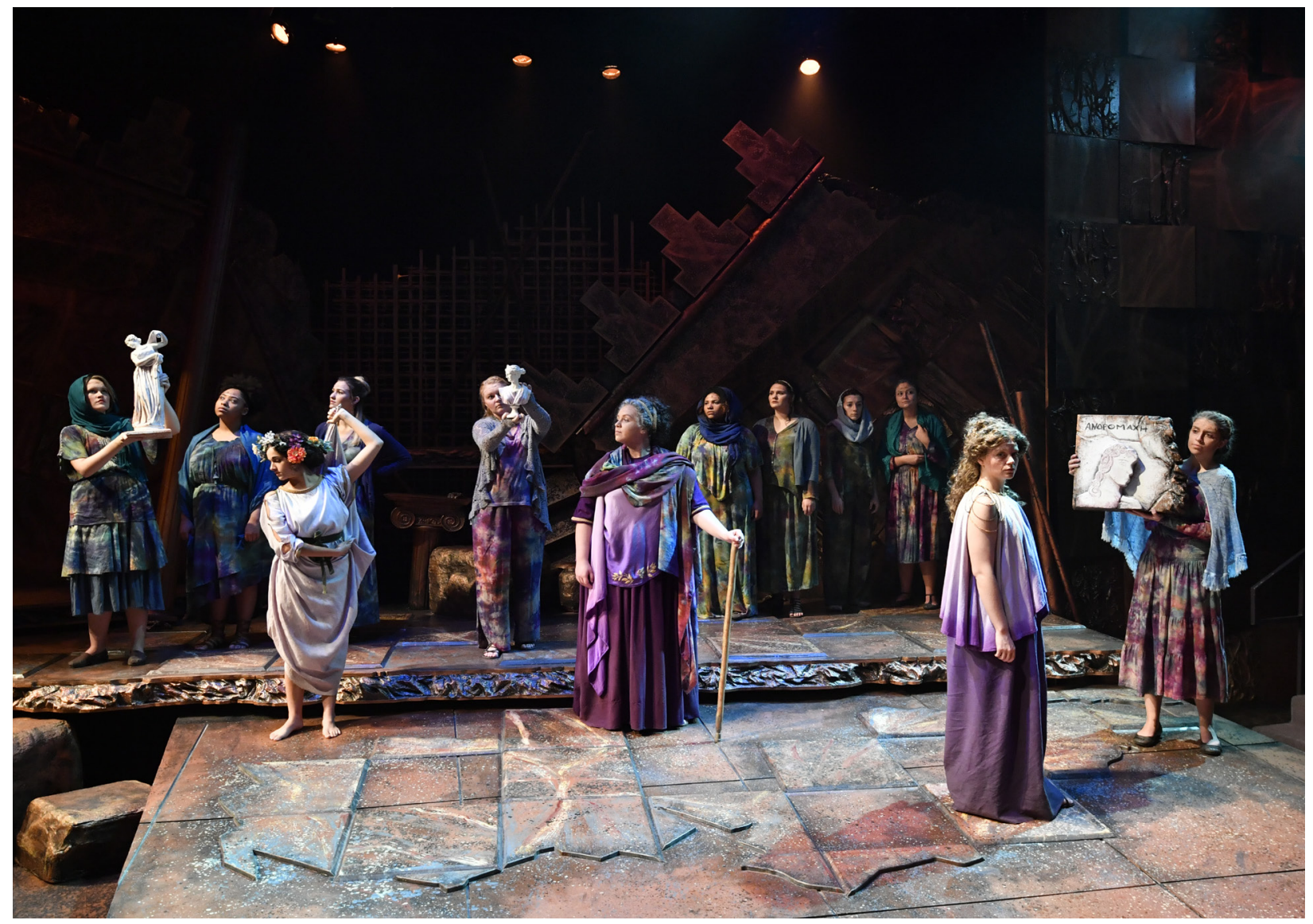

Figure 1: Production photo of Trojan women and Chorus. 
He singles out Hecuba who is old and walks with a cane. She is only valuable because she was the Queen of Troy. Next Poseidon talks about Hecuba's daughter Cassandra. She is young and beautiful. She was a priestess for Apollo and can speak in tongues. Because she is a holy virgin, she is prized immensely. Before exiting Poseidon warns the invaders, "But you will die, because Troy dies, because everything dies.” (MacEwen, 4)

The chorus of women expresses their despair and laments that morning will never come. The gods to whom they have been praying have left them alone. These women remain with nothing. Throughout the play the chorus repeats that "time has learned nothing." (MacEwen, 5)

Hecuba cries out for Troy. Once a queen, she gave birth to Hector, who was a great warrior. She used to believe in Troy, and lived for Troy but her faith did nothing to stop the destruction. She understands the reality of what is happening, namely, that her husband and sons are gone. This great and honorable city that she loved has turned to nothing. Even in her suffering, she believes that the gods must have some greater meaning for this destruction. Then she sees the hut where Helen, the runaway wife of Menelaus, is kept and yells at her. Helen came to Troy dragging this war behind her. Hecuba is angry and denounces her, calling her the slut from Sparta. She compares Helen's evil to the purity of her own daughter Cassandra. Hecuba believes them to be exact opposites.

Hecuba explains to the chorus women their fate. They will be taken to faraway lands. The chorus cries out in fear and wonders where they will be sent. Cassandra instructs the chorus of women to sing a new song. She explains that she plans to go willingly to the Greeks.

The Greek messenger Talthybius enters and informs the women that the lots have all been cast. Cassandra eagerly asks him with whom she will be going, and wonders what he will do 
with her. He tells her that she will be going with Agamemnon, King of Greece, and implies that Cassandra already knows what Agamemnon will have her do. Hecuba attempts to shelter Cassandra from this comment but Cassandra only laughs. Cassandra tells her story of how she used to speak in the voice of her god who informed her of the future. She no longer has use for the gods. She has decided that life is too short and she is too young. What good has come from her being a part of "good" society? To Hecuba's horror, she curses the city of Troy. Cassandra continues to rant about how wars create absurd heroes. She yells that she has seen the future, and knows there will be other wars and history will continue to repeat itself. She then exits off to the Greek ships. Hecuba is in shock that she never truly knew her daughter. She wants to call upon the gods and have faith they are still there, but struggles knowing everything has been ripped away from her.

The chorus tells the story of Troy's destruction. They sing of the Greeks bringing a great horse to the gates and proclaiming it as a peace offering. They sing of how the Trojans celebrated all night with music and dancing, not knowing the horrors that lurked inside. They danced and praised the gods until they fell asleep. At the precise moment, the Greeks emerged from hiding and slaughtered them. Blood ran through the streets like rivers. Their song ends with powerful lines that appear throughout the play "Troy dies, everything dies! Everything dies but death!” (MacEwen, 30)

As the chorus falls silent Andromache enters crying out for Troy. Holding her hand is her young son. She is scared and weeps for her husband Hector, a prince of Troy, who was killed in battle. She recalls how she was the perfect wife, but now struggles to find meaning in her existence. She knows she is to be given to Achilles, the Greek who murdered her husband, 
but does not know how she can serve such a man. She expresses that her only hope lies in the thought that her son may grow up to be the savior of Troy and rebuild the city.

Talthybius enters and explains to Andromache that Ulysses has commanded that her son must die. The Greeks cannot risk having the child grow up to avenge his father's death. They plan to throw him from the walls so that it will be a quick death. If Andromache resists they will not give the boy a proper burial. She does her best to comfort her son by telling him he's going to be with his father and sends him off with Talthybius. As they exit, Hecuba screams that she hopes history remembers that the Greeks were afraid of a child.

Now without a husband or child, Andromache feels she is nothing. For her self-worth is is gone. The soldiers lead her away to the ships. Hecuba knows she cannot judge Andromache for feeling this way. All the women of Troy have lived their lives through men and knew that was their role in life. None of them really know who they are on their own.

King Menelaus enters pondering what he should say to Helen when he finally sees her after all this time. He debates whether he should enjoy her or kill her, perhaps both. When Menelaus spots Hecuba, he demands that she tell him where Helen is. Hecuba spits in his face. He realizes who she is, Queen of Troy. As King Menelaus tells Hecuba what a great ruler he is as she yanks off his glorious helmet exposing his balding head. Hecuba informs him she wanted to see what this "supposedly" great conqueror really looks like. Menelaus then asks for Hecuba's advice on what he should do with Helen. Hecuba laughs at this request. He is offended, and in his anger yells to his men to bring Helen out to him. Hecuba warns him to tread carefully because Helen is a liar.

Helen plays the victim and begs Menelaus to let her speak in her own defense. She tells 
him there are two sides to every story. As she pleads, the chorus mocks her words. Menelaus prepares to kill her but Hecuba stops him, imploring him to hear Helen out. Thus, Helen begins her story. First, she blames Hecuba for giving birth to Paris, knowing the prophecies stated that he would bring destruction to Troy. Next, she blames Paris for choosing the gift of a beautiful woman instead of money or wisdom. Helen says she was kidnapped and brought to Troy, and that she tried to escape many times. She cried out and tried to climb down the walls of Troy. At this point, Hecuba has had enough and calls her a liar. Helen responds by saying, "I don't tell lies, I alter truth sometimes until it suits me" (MacEwen, 58).

As Helen flirts with Menelaus, his anger softens. She tries to convince him that she never loved Paris. However Hecuba places doubts in his mind by asking Helen, "You tried to escape, Oh help, help! You were dangling in mid-air! Who ever saw you? Name one! When did it happen? Who were the guards?" (MacEwen, 63). She tells him how Helen only praised the Greeks when she heard they were winning. Yet when she thought Troy was winning, she then sang for them instead. The chorus taunts Menelaus repeating Hecuba's words. He does not really believe Helen, but as the chorus hisses he grows unsure. Finally, he decides to think about it and kill her later once he is back in Sparta. As Helen exits, Hecuba warns him that he may fall for her tricks again. He is arrogant and feels he is a wise military man. As he exits he states, "I know exactly what I'm doing!" and leaves in the wrong direction, reenters then motions for his soldiers to follow him off in the correct direction.

Talthybius enters with two soldiers carrying the boy's body on his father's shield; they lay him at Hecuba's feet. Andromache had asked as she was taken on the boat that the boy's body be brought to Hecuba to be wrapped for burial. Hecuba weeps over the body of the boy. The chorus 
brings her flowers and bits of cloth to cover the body. Until now she has remained strong, yet seeing the tiny body of her grandson unravels her. Nothing matters to her anymore; all has been lost to her when his life was taken. She cleans his wounds, and gives him pitiful bits of cloth, which is all she has left. By burying him she buries any hope she had for the future.

As the chorus slowly exits carrying the boy's body off to the beach for burial, Talthybius enters. He is to take Hecuba to the ships. He tells her that it is all over and now it is time to go home. She reminds him that it will never be over, that this will all happen again. She exits leaving Talthybius alone on stage. His words mirror the opening lines of Poseidon. He says goodbye to the broken walls of Troy and sings for the great city that once was Troy. 


\section{DESIGN PROCESS AND CONCEPT}

In the spring semester of 2016 the production team met to discuss initial reactions to The Trojan Women. The director, Dr. Malarcher opened by asking the design team to talk about their thoughts on the script. I started by discussing the fact that this version is far more focused on the emotional pain of the women, as opposed to Eupidies' original version, which focused on the loss of the city.

Dr. Malarcher agreed that MacEwen's adaptation has a feminist slant, but more importantly to him her work has a "poetic quality that seems to jump off the page." James Raymond, the scenic designer, grasped onto the harsh reality of the story and how these women were stuck in the worst possible situation. Dr. Malarcher said, "There is a collateral damage in every war. Collateral damage is a nice expression for what we suffer and how people become hardened to that reality. This play is a great reminder of how we as human beings must put the pieces together after we tear things apart." (Malarcher, Initial Design Meeting). Prof. Alan McEwen, the lighting designer, expressed that the play shares timeless truth. The timeless aspect then became the central focus of the remainder of the meeting. We discussed how we could move away from this being a play only about the Greeks in their own period. It was important for the play to feel grounded in reality but also that it allow the audience to see that this kind of disaster is not unique to any one period of time. As we discussed the concept of timelessness, Dr. Malarcher reminded the team that we should be using theater language to tell a theater story that is as old as theater itself. Throughout the summer months this conversation continued and evolved into what would become the final design concept for The Trojan Women. 
Through one-on-one conversations with Dr. Malarcher we were able to discuss in detail the characters and what each role meant to this production. During one of these meetings Dr. Malarcher formed the idea to pair Poseidon's opening speech with a modern dancer. Starting the show with poetry in motion opened up the visual aspects of the play to a stylized world. In conversation, Dr. Malarcher continually used the words "poetic" and "spectacle". Poetry can be sad and awful but still beautiful. This beauty-in-pain became the over all feeling I wanted to be reflected in the design.

Since much of the design discussions were over the phone and through e-mail I created a PowerPoint of research images and design ideas (See Appendix I). This allowed me to organize concepts in a clear manner and share them with the rest of the design team.

In order to give the play a timeless mood, we chose to dress the chorus in modern clothing, and the lead characters in more traditional ancient Greek garb. To bridge the gap between time periods, the chorus would wear masks when they directly interacted with lead characters. The soldiers functioned as a male version of a chorus with helmets as their masks. To help maintain division between the opposing sides of the war, I chose to use a controlled color palette. The Greeks were dressed in reds while the Trojans wore various shades of purple. The chorus women wore predominately blues and purples to tie them both to Poseidon and the Trojans.

It was helpful to sit in on auditions while designing this production. The movement and scene work Dr. Malarcher had the actors doing gave me a stronger sense of what he was looking for in the production. The actors moved smoothly as a unit across the floor interacting with one another without ever touching almost as if preforming a dance. I knew I wanted to carry 
the fluidity of their movements into the costume design by using swirling dying techniques and light flowing fabrics.

Because this was the last show of our season, I had the privilege of knowing my cast before my final designs were due. This gave me the opportunity to make the appropriate adjustments and draw the designs specific to each actor. The Poseidon dancer was the only character not cast until later. I was hopeful that it would be Michael Morris, an undergraduate dance major who had been discussing the part with Dr. Malarcher. I designed the character with him in mind and was later excited to find out he had been given the role. 


\section{RESEARCH}

Because the main characters are a part of a larger mythology, I began by researching their involvement in the Trojan War. I discovered Trojan War: The Podcast by Jeff Wright. Wright is an educator and storyteller who compiled a twenty-episode podcast telling the entire epic of the Trojan War. Because Greek mythology has many variations at the end of each episode Wright includes a commentary explaining other versions and why he chose the content he included. Listening to this gave me a solid foundation to better understand the full story of The Trojan Women. For example, in understanding that Helen was given to Paris as a prize by the goddess Aphrodite I began to pity her character. She was as much a victim of the war as the women of Troy.

Reading the 2016 book Theatre of War by Bryan Doerries helped refocus the way I thought about the play itself. His book is about the theater company he formed called Theatre of War. This company performs the Greek story of Ajax by Sophocles for soldiers returning home from war. "It has been suggested that ancient Greek drama was a form of storytelling, communal therapy, and ritual reintegration for combat veterans by combat veterans" (Doerries, Overview, Theater of War). The book not only explains what the theater is doing but also the reactions it received from the audience of soldiers. Many soldiers were able to open up because they felt connected to the characters. They realized people have experienced similar traumatic events for thousands of years. This confirms my view that Theater has the power to change the way people think and feel. Hearing the stories of so many soldiers that were angry and on the verge of suicide but had their life changed by watching one performance gave me a renewed perspective 
on the subject. It provided me with a stronger drive knowing that this production could sincerely make an impact on how some people perceive war.

Building on my knowledge of Greek fashion from my education I researched appropriate looks for each character. I used artifacts such as reliefs (Figure 2), statues (Figure 3), and pottery (Figure 4) as primary historical research. I looked through notes from my costume history classes and at fashion history books such as History of Costume for the Stage by Lucy Barton. I wanted the costumes to feel as if they were historically accurate but contain a more artistic flair.

Because we were creating an artistic interpretation of the Trojan War, I considered depictions of each character

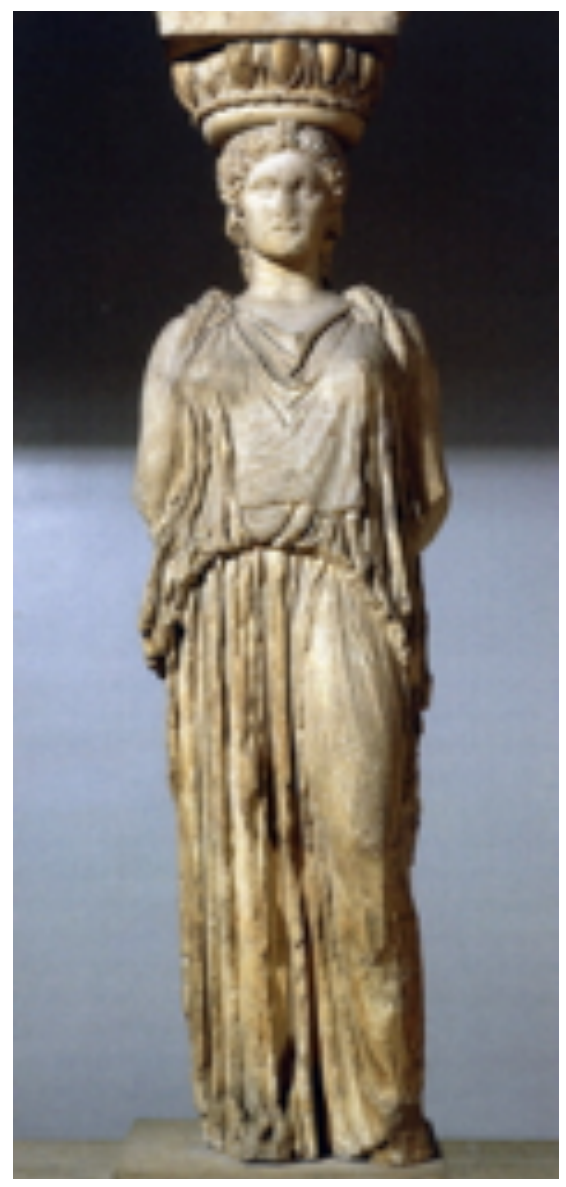

Figure 3: Research image of Greek statue. throughout history. Much of Greek mythology was passed

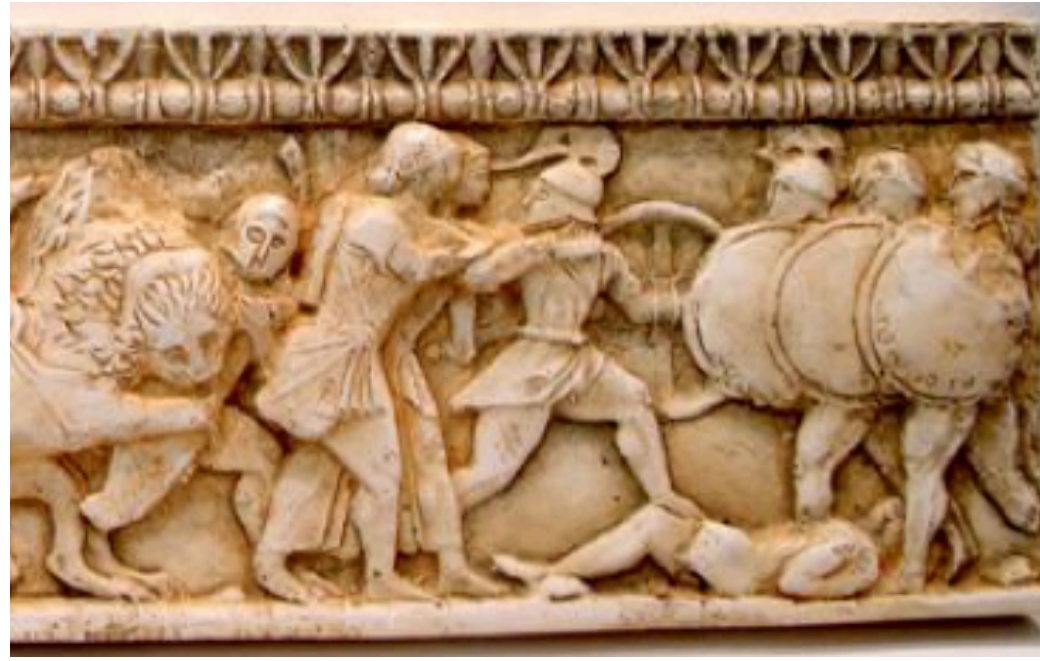

Figure 2: Research image of Greek relief dipicting Greek soliders.

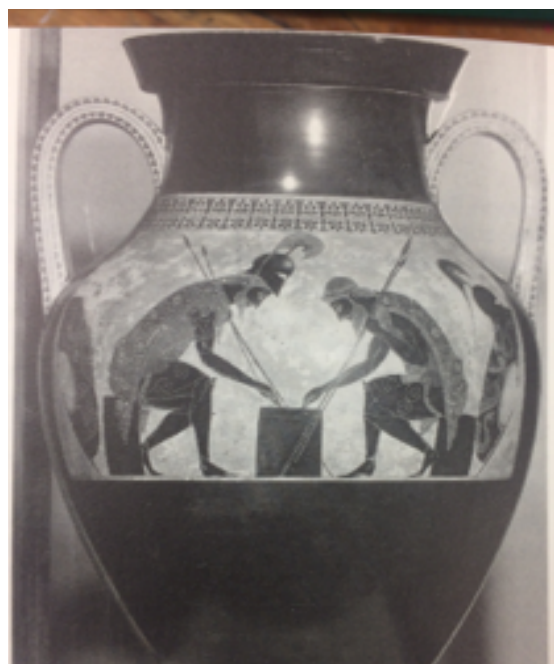

Figure 4: Research image of Greek pottery. 
down in the oral tradition so stories evolve in each version. I researched Greek statues (Figure

5) and pottery (Figure 6), Pre-Raphaelite paintings (Figure 7), and even contemporary digital art

(Figures 8 and 9). Looking at this wide variety of art helped me to compile my own aesthetic for each character.

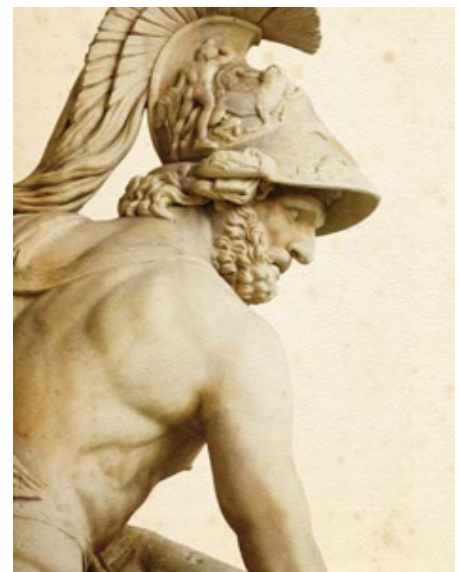

Figure 5: Statue of Menelaus.

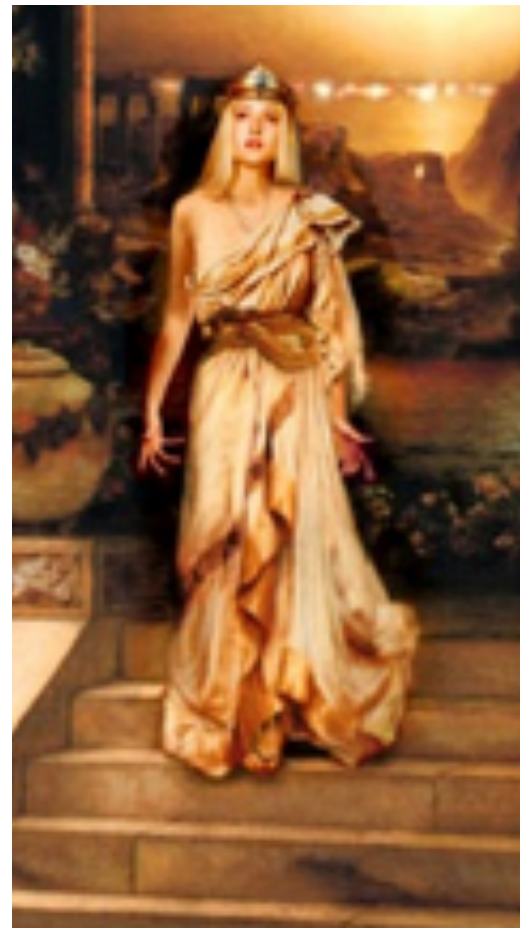

Figure 8: Digital rendering of Helen.

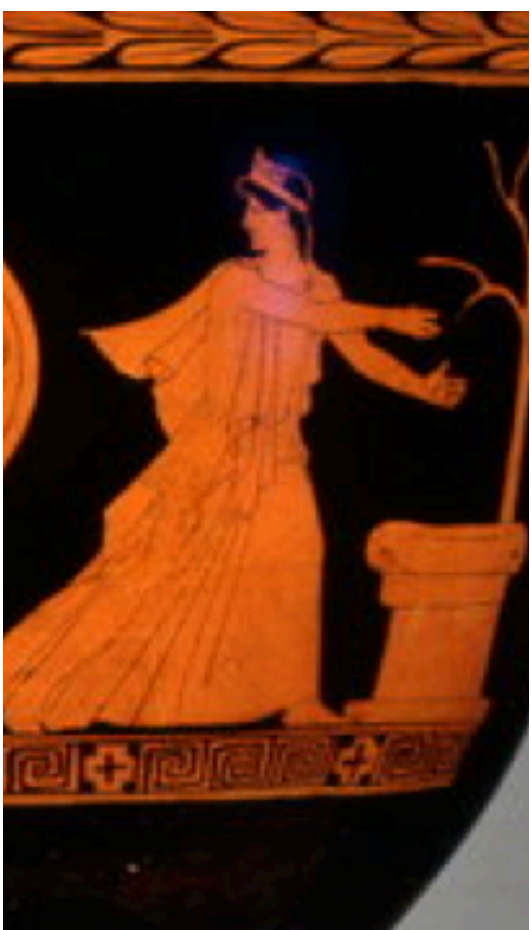

Figure 6: Helen on Greek pottery.

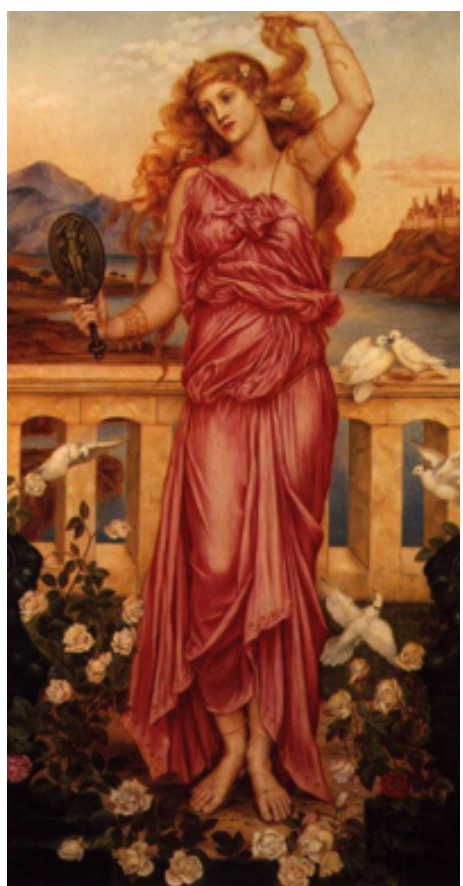

Figure 7: Pre-Raphaelite panting of Helen.

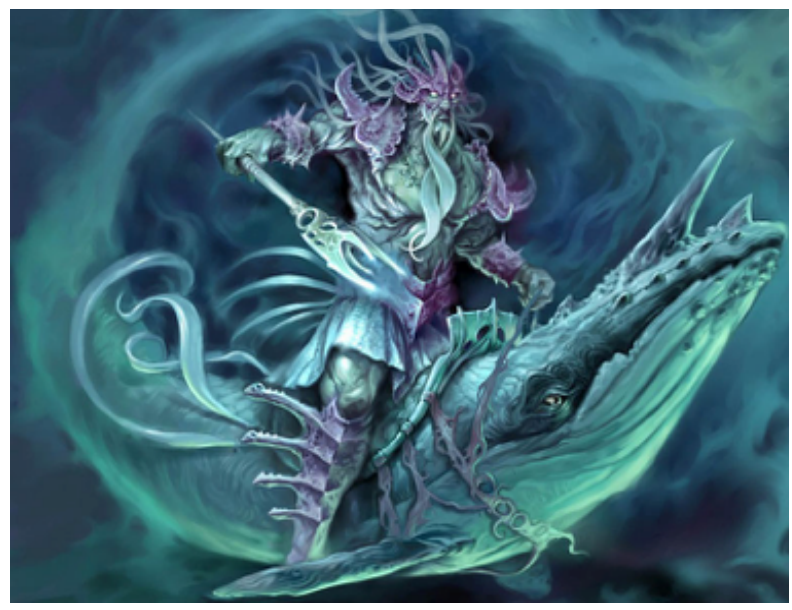

Figure 9: Digital art image of Poseidon. 
The colors in ancient Greece are not the white marble that is often depicted in popular culture. German archeologist Vinzenz Brinkmann created a technique to show what Greek statues and architecture looked like during the ancient Greek period (Figure 10), approximately 1200BC-320BC. The technique tests traces of pigments, analyzing them in order to determine what color had originally been there. The playwright, Euripides gives clues as to how Greece was painted in his day with lines from his play Helen: "If only I could shed my beauty and assume an uglier aspect the way you would wipe color off a statue." (Euripides)

The Greeks used colors like saffron, red, green, black, blue, off- white, golden brown and purple. Purples and reds were rare and worn by royalty due to the expensive process to make the dyes. Purple was made from the murex, a sea creature.
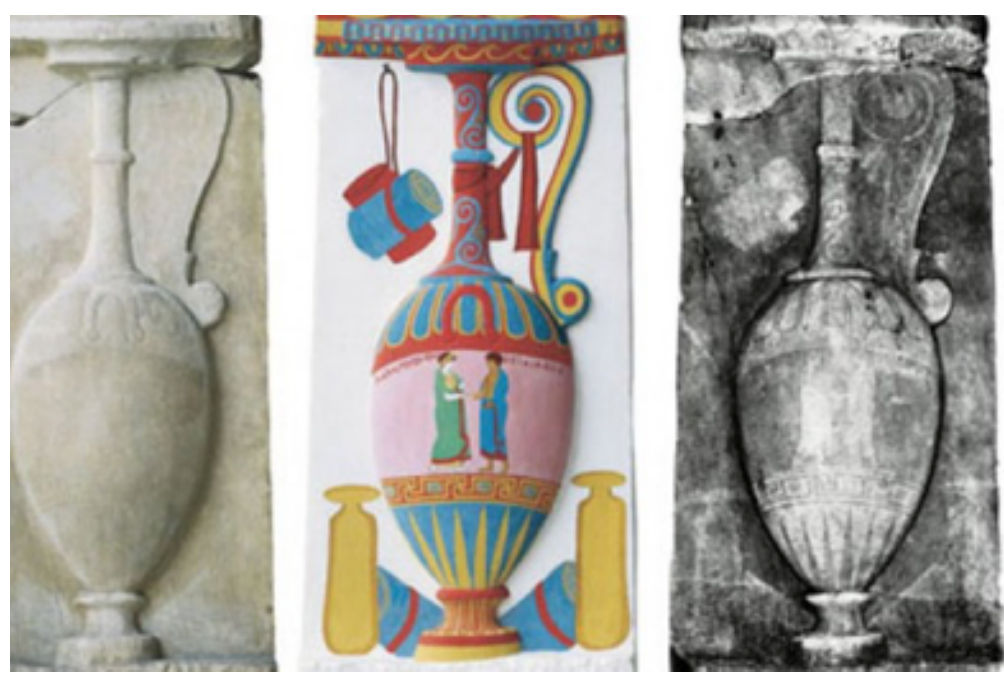

Figure 10: Digiality colorized rendering of Greek carving.

Red was made from the dried

bodies of female insects in the genus Kermes.

Made from natural fiber, fabrics were mainly woven in the home. Garments were comprised primarily of wools and linens. This is because the materials were easily attainable since they came from sheep and the flax plant, which were readily available in that region. Wool and linen were both woven in varying degrees from course to very fine. Looser weaving techniques created fabrics, which hung nicely. This was important since the beauty in their 
garments was about how fabric draped around the body.

Weaving fabrics was time intensive so only the wealthy could afford to wear large amounts of fabric. Some of the upper class even wore garments made of silk which was a rare and costly material.

Since clothing was not fitted, there was little distinction between the male and female silhouette. Garments were created by draping and pinning a singular piece of fabric around the body in different configurations. The most common garment was the chiton (Figure 11), which was a loose-fitting tunic with little or no seams. There are two types of chitons: Doric and Ionic. The Doric chiton was a short, one or two-shouldered garment worn by men. Ionic chitons were long garments pinned at both shoulders worn by men and women. Women would often wear a type of chiton called a Doric peplos (Figure 12), where the top of the fabric was folded down then pinned at the shoulders creating an additional layer on the upper body.

They also had several types of outer garments. The chlamys (Figure 13) was a short cloak pinned in front of the neck or on the shoulder. This was typically worn by

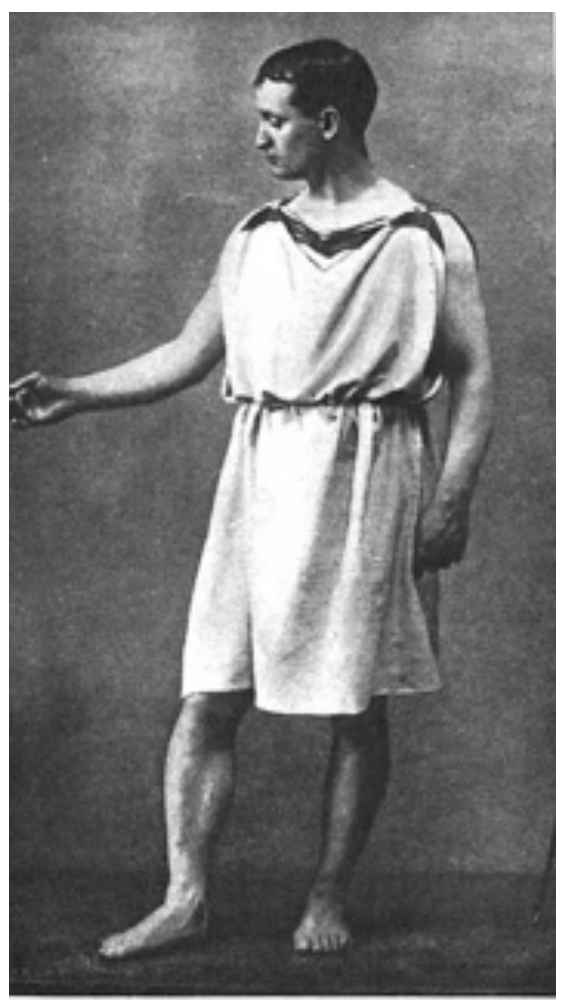

Figure 11: Research image of a man wearing a Greek style chiton.

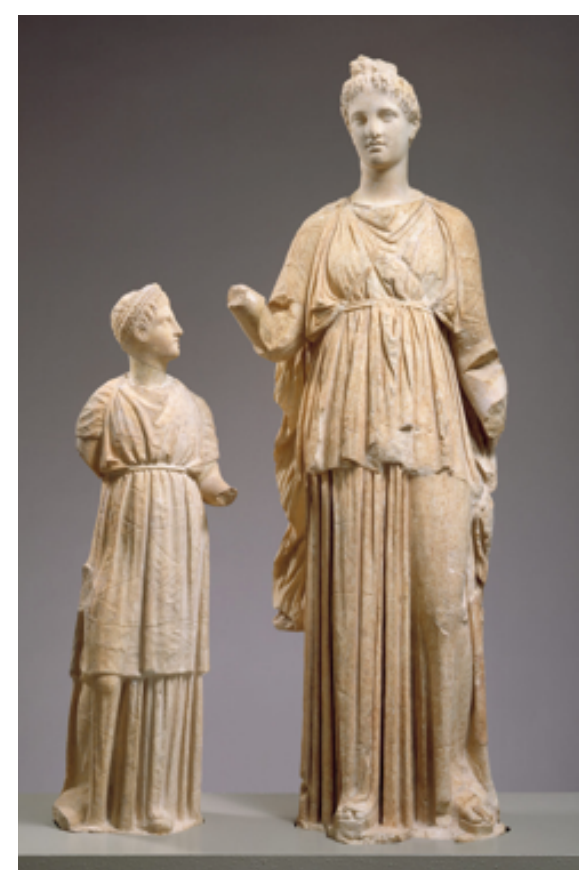

Figure 12: Research image of a Doric peplos. 
young active men, on its own or over a short chiton. Women had a similar garment called a diplax, which they wore over a chiton. Himations (Figure 14) were long rectangles of fabric that wrapped around the body and were worn by both men and women. Women always wore them as an outer garment where men sometimes wore one on its own.

Footwear was rare in ancient Greece. Most people went barefoot almost their entire life. People who worked outside or who were traveling were more likely to wear simple sandals. The armies sometimes wore footwear such as buskins, which were a style of sandal that laced up the leg.

In early Greece soldiers often fought naked, wearing only a chlamys and a helmet. As time went by they dressed in chitons and began wearing types of armor. A cuirass

(Figure 15) was a fitted bronze chest plate that sometimes had leather tabs attached, which hung down to protect the thighs. Later, they created the chest plate from leather and covered it with bronze tabs allowing for more movement in battle. A thinner lightweight armor was the linothorax (Figure 16). This was made with many layers of stiff linen laminated with hyde glue to create a hard shell. Often there were strips of the same material attached like a skirt to protect the thighs.

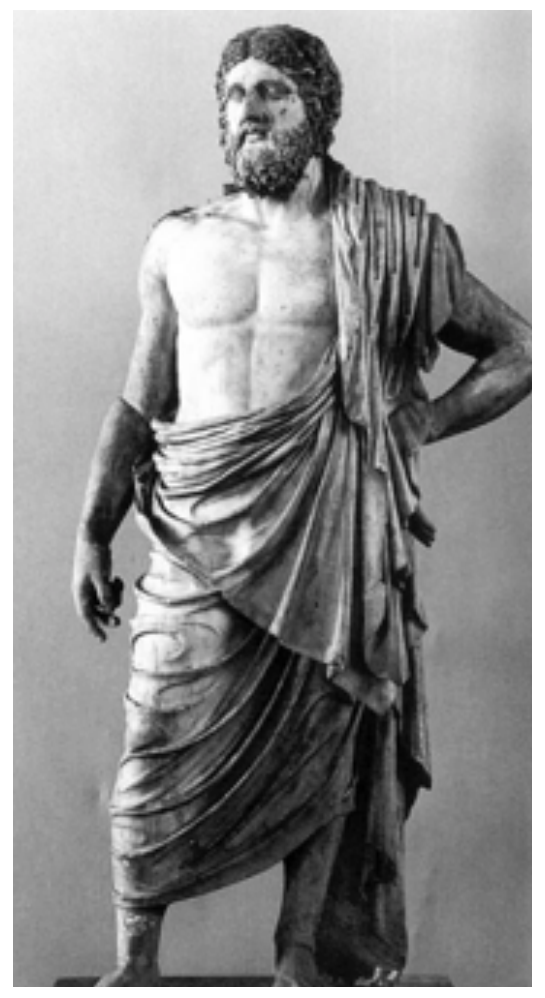

Figure 14: Reaearch image of a himation. 
Soldiers would wear shin guards called greaves that attached with leather straps. When helmets were worn, they were decorated in a variety of styles. Some adorned with crests, plumes of horsehair or feathers.

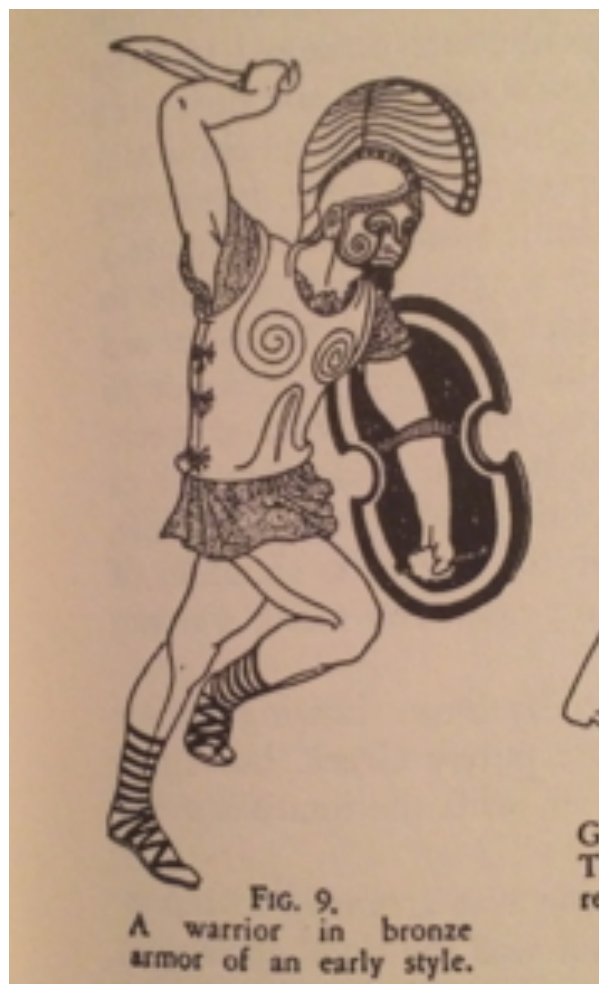

Figure 15: Research image of a Greek Soldier wearing a cuirass.

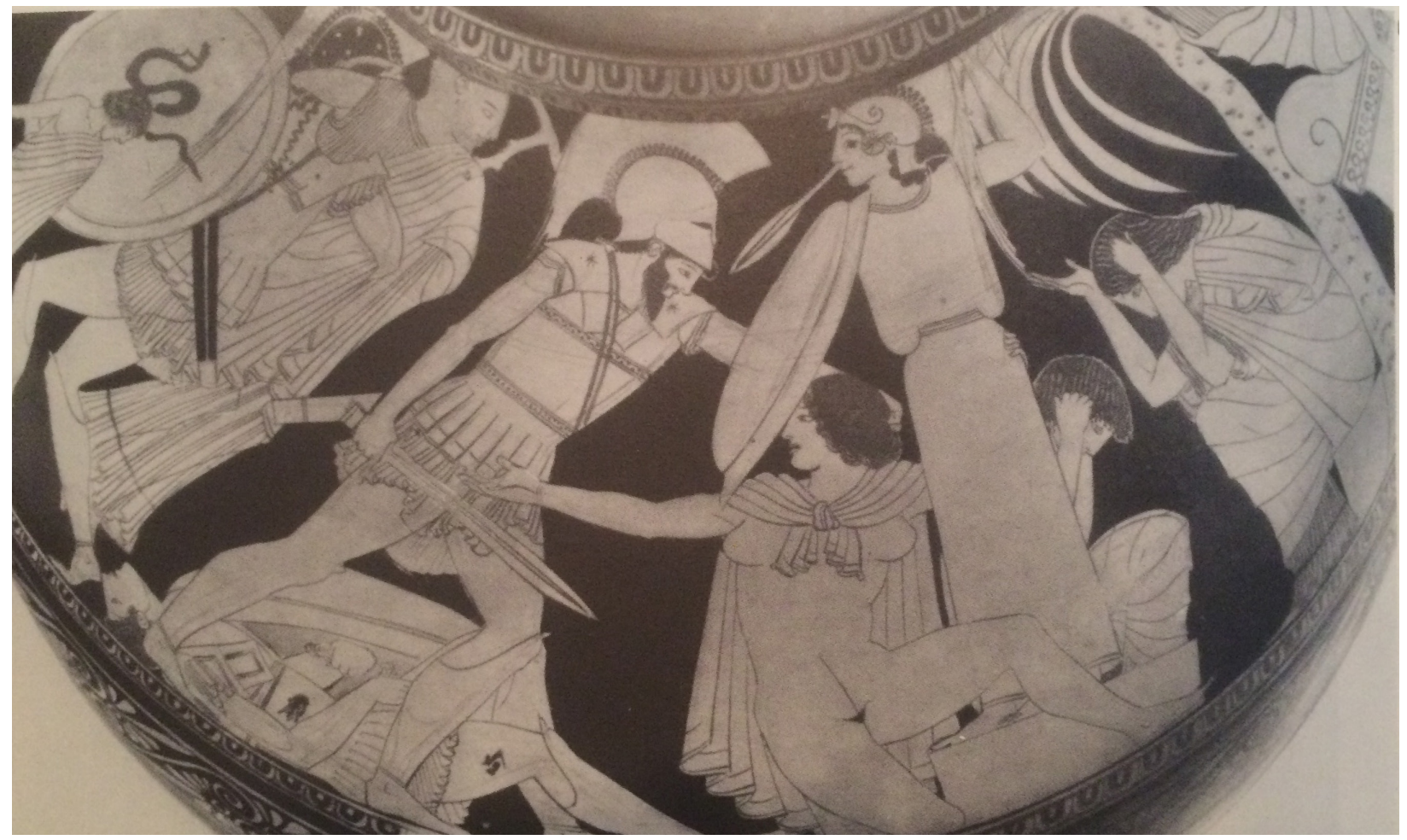

Figure 16: Research image of a soldier in the Trojan war wearing a linothorax. 


\section{CHARACTER BREAKDOWN}

\section{Poseidon Dancer}

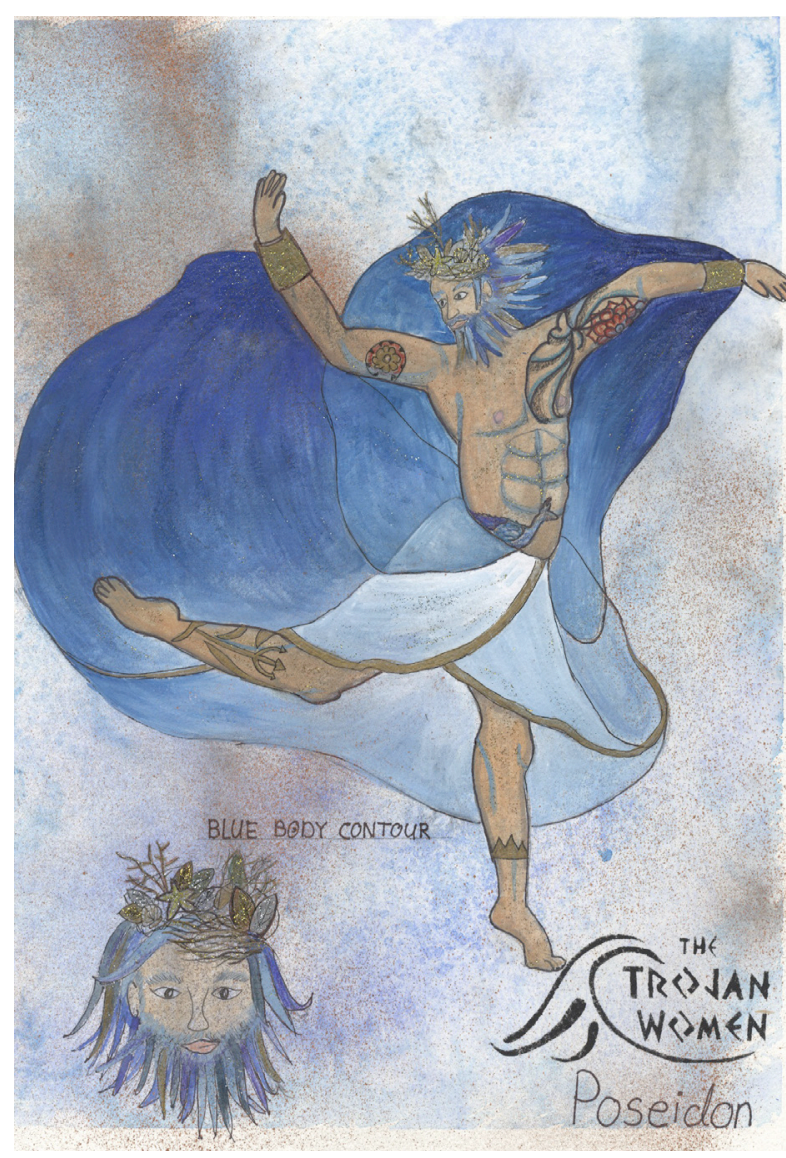

Figure 17: Final rendering for Poseidon.

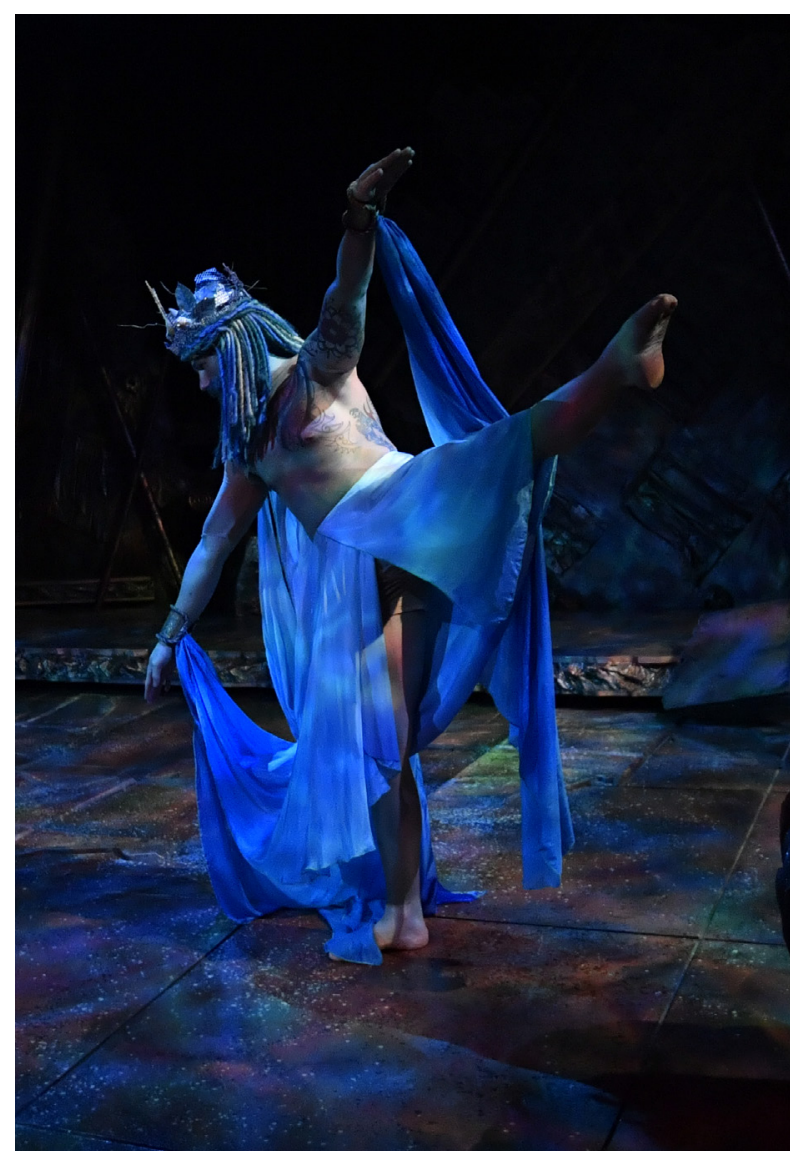

Figure 18: Production photo of Poseidon (Michael Morris).

Poseidon is the god of the sea, earthquakes, storms and horses. He built the walls of Troy and is connected to this city.

Dr. Malarcher knew early on that he wanted to open the show with a statement piece.

After it was decided to make the character of Poseidon a dancer, I worked closely with the sound designer Ricky Moats to create a cohesive piece between sound and costumes. Because we did not have a dancer or chorographer, Dr. Malarcher provided us with a video clip of Michael Clark's dance in his role as Caliban from the film Prospero's Books (U.K., 1991; director Peter 
Greenaway). The style of movement in the clip evoked what he wanted for Poseidon's dance piece.

I wanted to make sure the costume embodied iconic aspects of Poseidon while allowing for all necessary movement of the dancer. Poseidon is often depicted rising out of the water, so I wanted his costume to evoke the same feeling. I dressed him in a layered

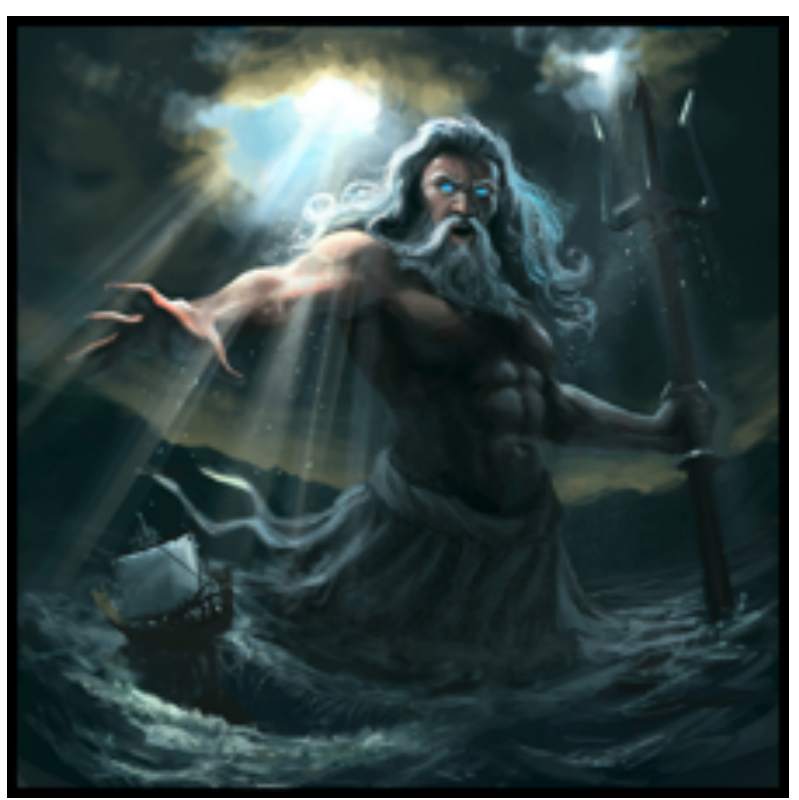

Figure 19: Inspiration image of Poseidon rising out of the water. wrap skirt, the two longer layers draped to the floor before being attached to gold cuffs worn on his wrists. The over skirt was made of silk habotai that flowed like water as it moved through the air. His costume was dyed in a gradation from deep blue/purple at the bottom to white as it reached his upper body mimicking the crest of waves (Figure 17).

In Greek mythology, the gods are often described as being surrounded by a veil of mist because humans could not handle seeing their true form. To support this god-like aesthetic, blue body contour makeup and gold shimmer were added to the Poseidon design so that his skin would glisten in the light. This shimmer had a dual purpose; giving the actor's skin an

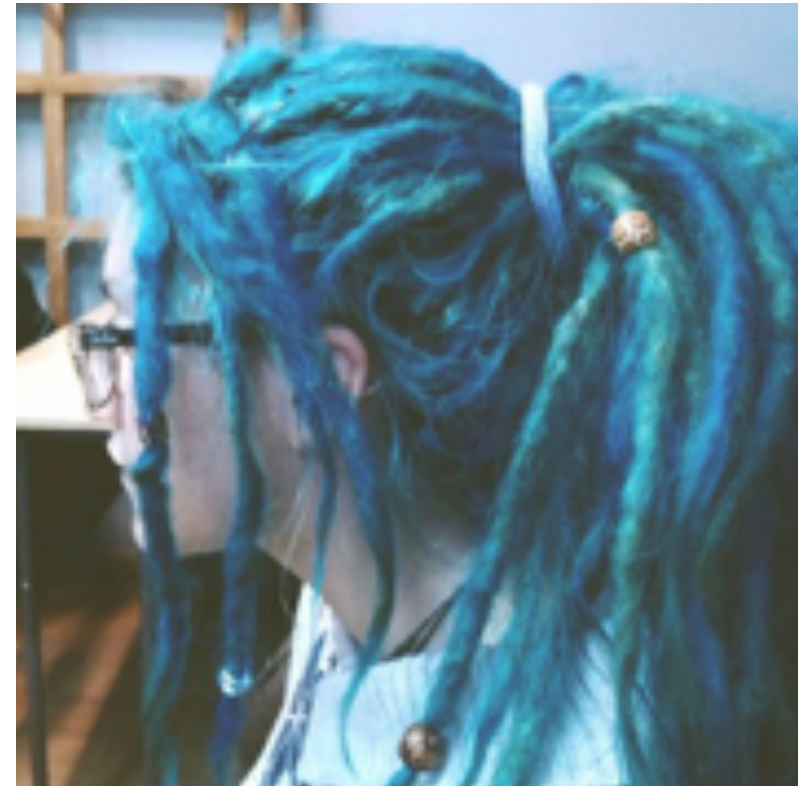

Figure 20: Research image of blue dreadlocks. 
inhuman glow and adding a glistening effect. Making Poseidon's skin look as if he had just risen out of water. He needed to feel as if he was not only a god but also a part of the sea (Figure 19). For his hair I designed a blue, green, silver and purple dreadlocked (Figure 20) wig and beard. The colorful dreadlocks had seaweed-like appearance making him look as if he were made from pieces of the ocean.

During the fitting process, a cape composed of the same silk habotai as his skirt was added. The back of the costume felt too plain in comparison to the rest of the costume. It also added more water-like movement as it flowed behind the dancer.

In the script, Poseidon wears a mask during his speech at the beginning of the play, which Talthybius symbolically places on the stage at the end of the play. Dr. Malarcher originally discussed doing an alternate ending using a speech by Poseidon instead of the current speech from Talthybius. This alternate ending eliminated the need for a mask for the character of Poseidon. After some consideration, he decided to maintain MacEwen's ending and asked if we could add a mask to the dancer's costume. Due to concerns for the dancer's vision being obstructed and the large amount of uneven surfaces on the set, we chose to add a crown (Figure 21) instead of a mask and have Talthybius throw it into the sea.

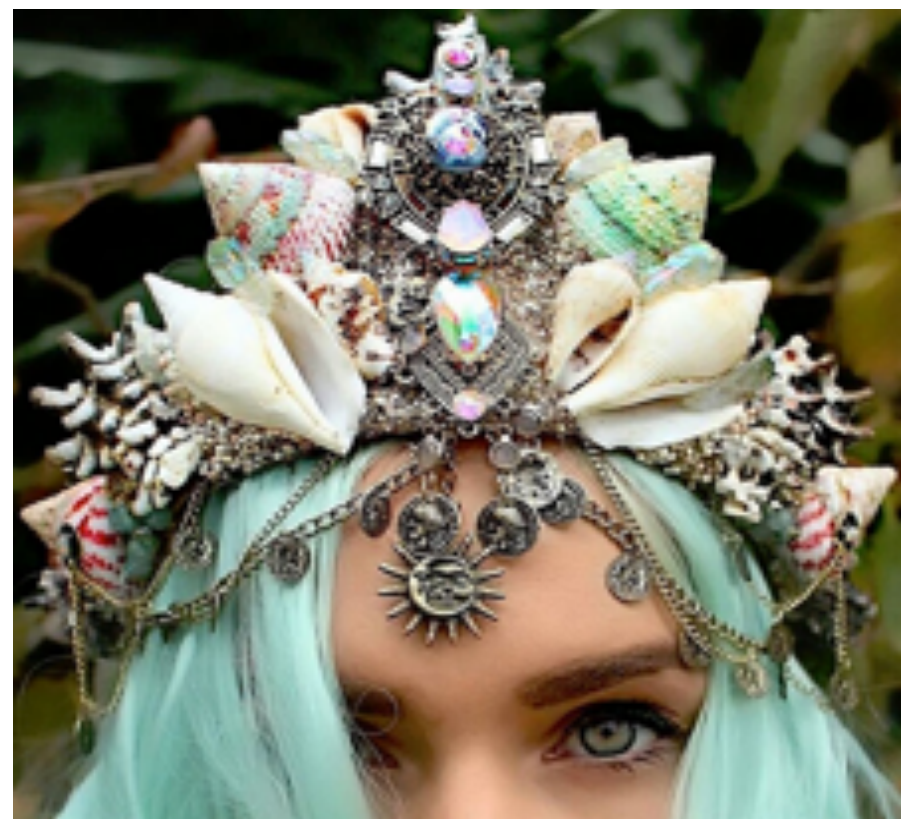

Figure 21: Research image of a shell crown. 


\section{The Chorus}

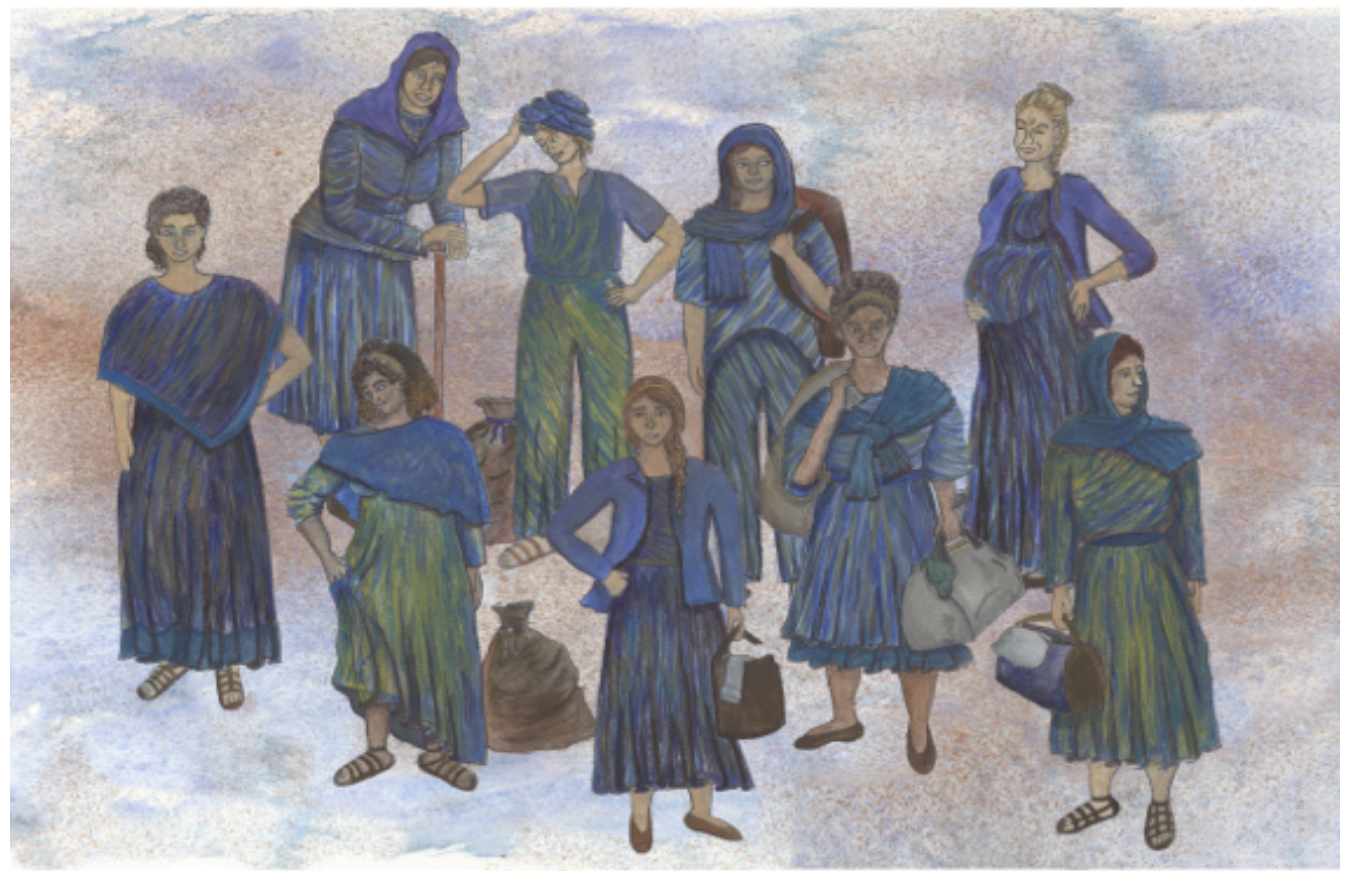

Figure 22: Final Rendering of the chorus.

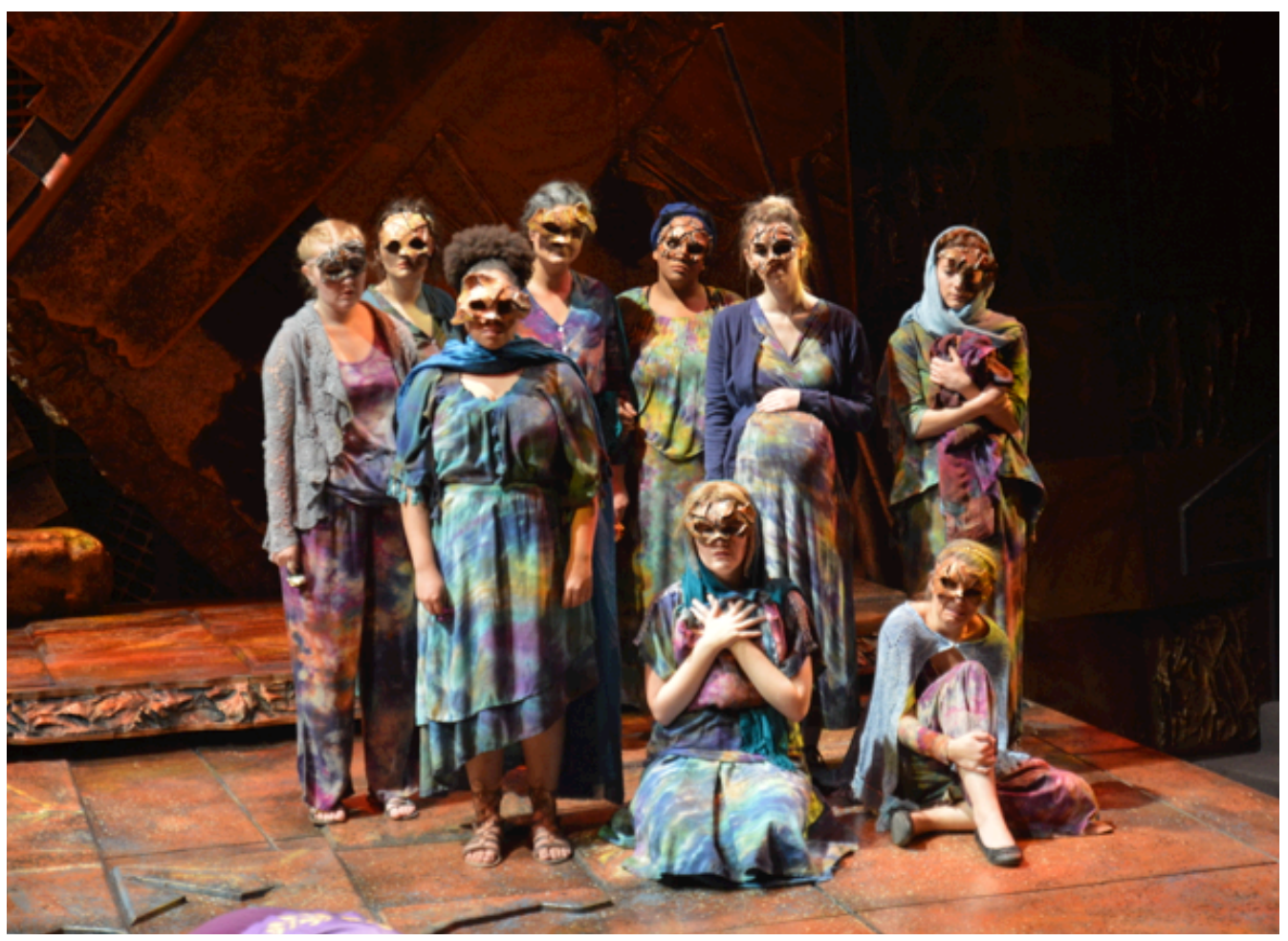

Figure 23: Production photo of the chorus (Taylor Morgan, Brianna Bowers, Abigail Cyphert, Briana Gause, Elise Rucker, Monica Hanigan, Deja Elliott, Katelyn Faussand and Nativa Kesecker). 
The chorus represented women who have been refugees of war throughout time. I wanted to make sure to allude to Middle Eastern culture but not any specific one. Dr. Malarcher's original idea was to have the women wearing hijabs but we chose to give them culturally non-specific headscarves. This ambiguity opened the door for more people to relate to the chorus. These timeless women wander among the rubble of Troy and are facing the same trials as the ancient Trojan women. By finding and holding artifacts like statues and pieces of pottery, the chorus could interact with history.

I researched photos of women who have been refugees or escaping from war during many different historical periods. I wanted to compile looks that encompassed everyone from ancient Troy, WWII Germany (Figure 24) and modern day Syria (Figure 25). Throughout the research process I found that no matter the period women seemed to wear many layers and quite often had their heads covered.

It was vital to the overall concept to give the chorus a different look from the Trojan

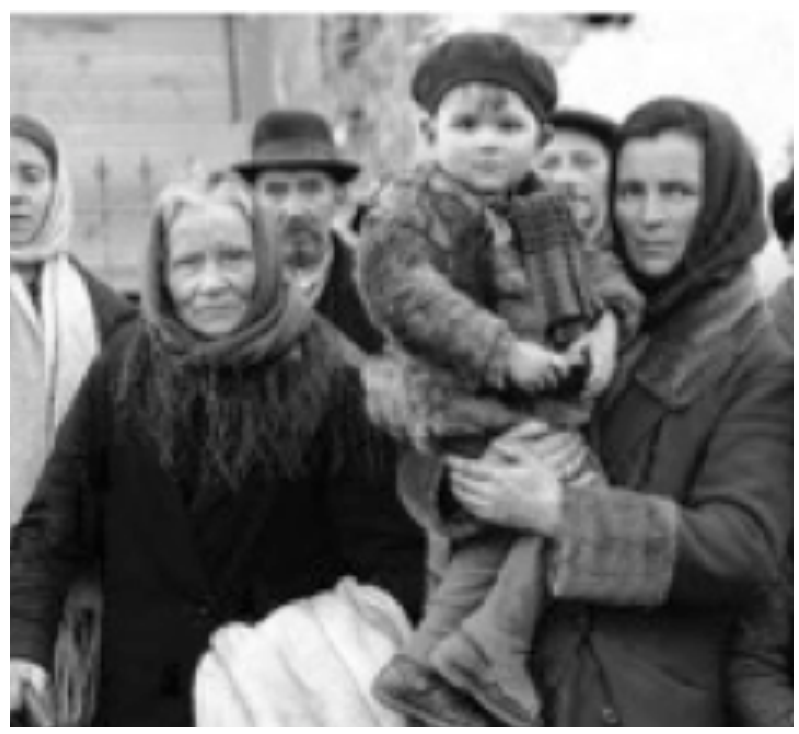

Figure 24: Research image of WWII German refugees.

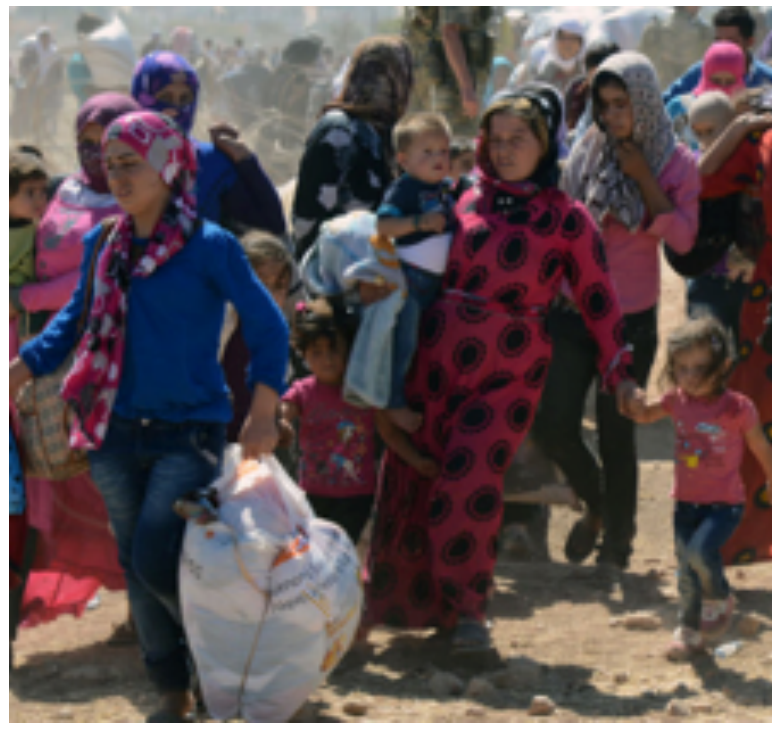

Figure 25: Research image of modern day Syrian refugees. 
women, but also include characteristics that could connect them. To solve this challenge the chorus women were all dressed in modern clothing that mimicked the silhouettes of the Trojan women. Dr. Malarcher wanted a wide range of ages within the chorus. I separated the nine women into three groups: young like Cassandra, mothers like Andromache, and old like Hecuba. The chorus' costumes were all dyed in the same color palette; each grouping was given a different dominant color. This allowed them to be a cohesive chorus while still maintaining the distinction. Because these women are in a transitional point of their life the inspiration for their color palette was that of when the ocean meets the beach, predominantly using blues and greens with touches of browns and purple. The solid ground of the beach is like the lives they know while the ocean is mysterious like their future. The youngest group included the whitest tones, like crests of waves. The middle group contained the most green representing fertility and new life. Purple accented the costumes of the oldest group, symbolically connecting them to the deepest ocean waters and wisdom.

This color palette was also chosen to match with colors of the scenic design. Originally, it was discussed that the chorus would have the ability to blend into the walls of Troy. This would show how strongly they were connected to their city because they are part of its walls, now broken, just like their spirits. In the end, this did not happen due to the scenic designer unexpectedly changing his color palette late into the design process. After discussions with the director we decided that the element of having the chorus blend in was not as important since we were conceptually moving in a different direction. Dr. Malarcher did not want the chorus women to feel as if they were from the same world as the set since they are strangers in this land.

In order to capture the feeling of traditional Greek theater we wanted to use masks. 
Initially, we were not sure if they would be appropriate for our production. Subsequently we decided that they would use masks to allow the contemporary female chorus to interact directly with the women of Troy. Since the chorus needed a visual way to connect to the Trojan women, I designed masks that were reminiscent of the rubble of Troy. Some masks were broken pieces of pottery (Figure 26) and others were shattered bits of statues (Figure 27 and 28). These masks were painted in the same coppers and browns of the set so that they would blend in entirely while sitting on stage. Each mask contained cracks that looked as if they were repaired with gold in the style of Kintsugi (Figure 29), the art of repairing broken pottery with powdered gold, silver or platinum. The use of this cracked motif helped support the concept that destruction and catastrophe have happened before and have been repaired. When the chorus members find the masks in the rubble and each woman applies her mask, they too become part of the rubble of Troy.

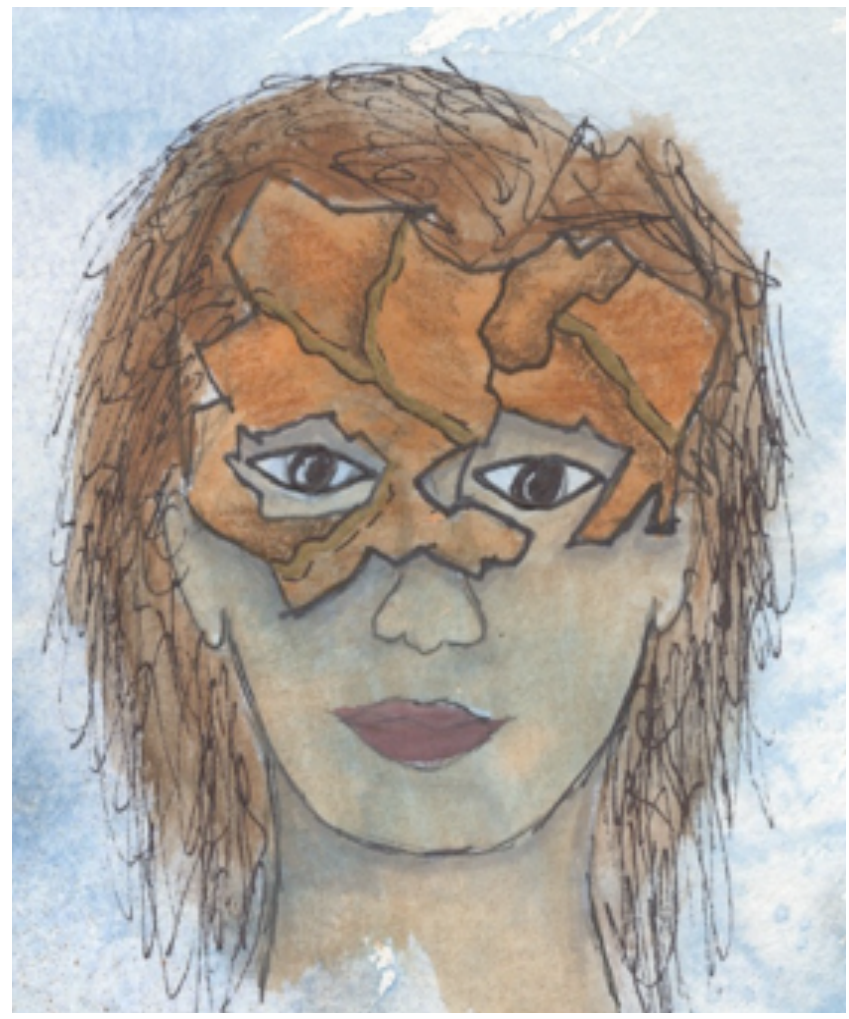

Figure 26: Final rendering of broken pottery mask.

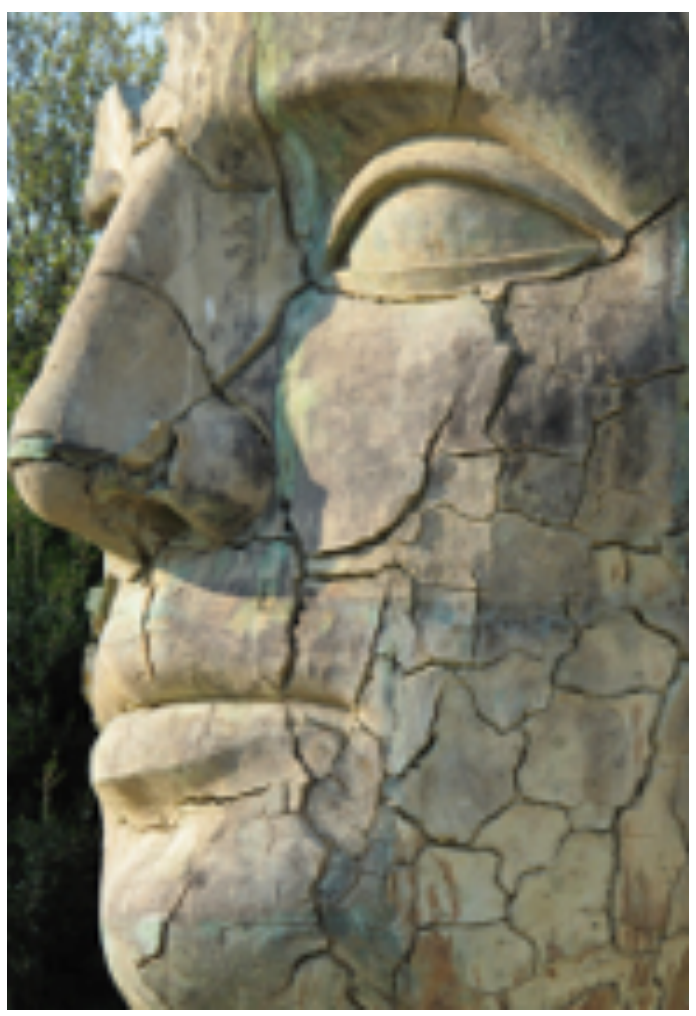

Figure $27:$ Research image of cracked statue. 


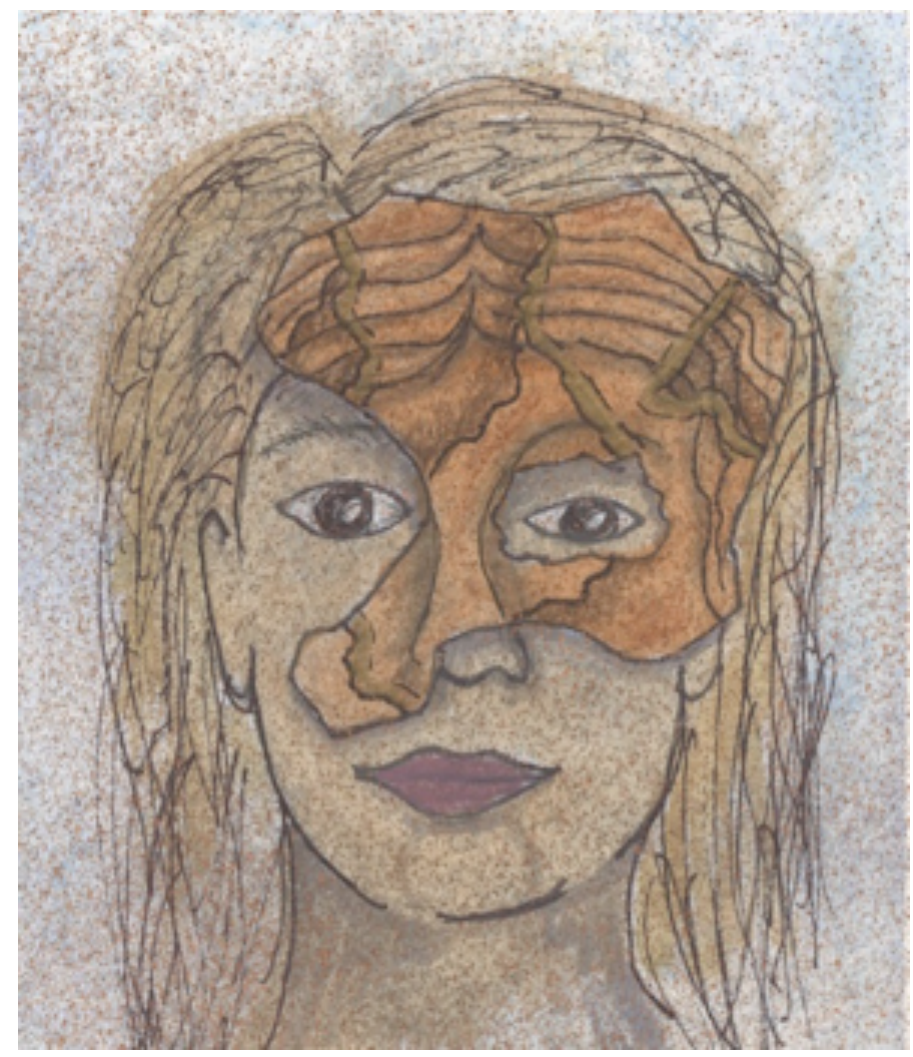

Figure 28: Final rendering of broken statue masks.

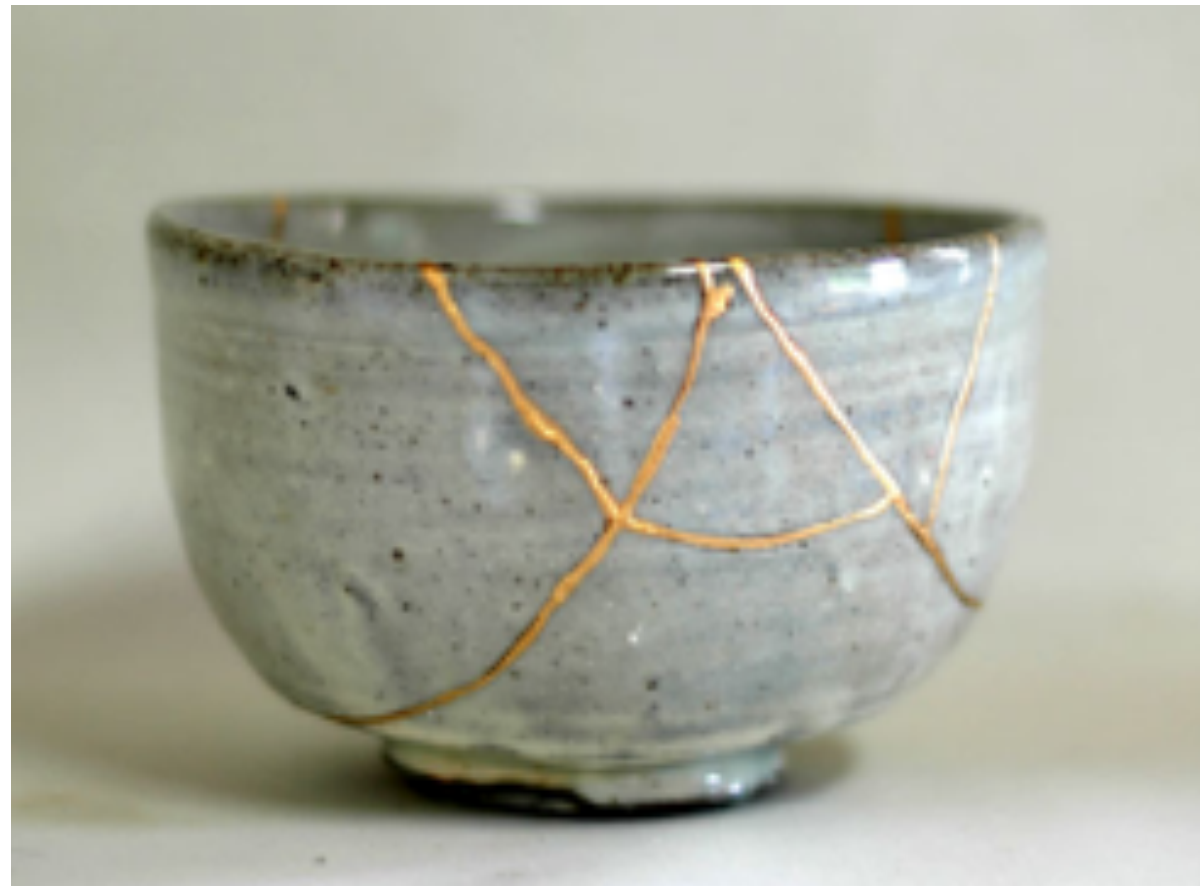

Figure 29: Research image of Japanese Kintsugi. 


\section{The Four Soldiers}

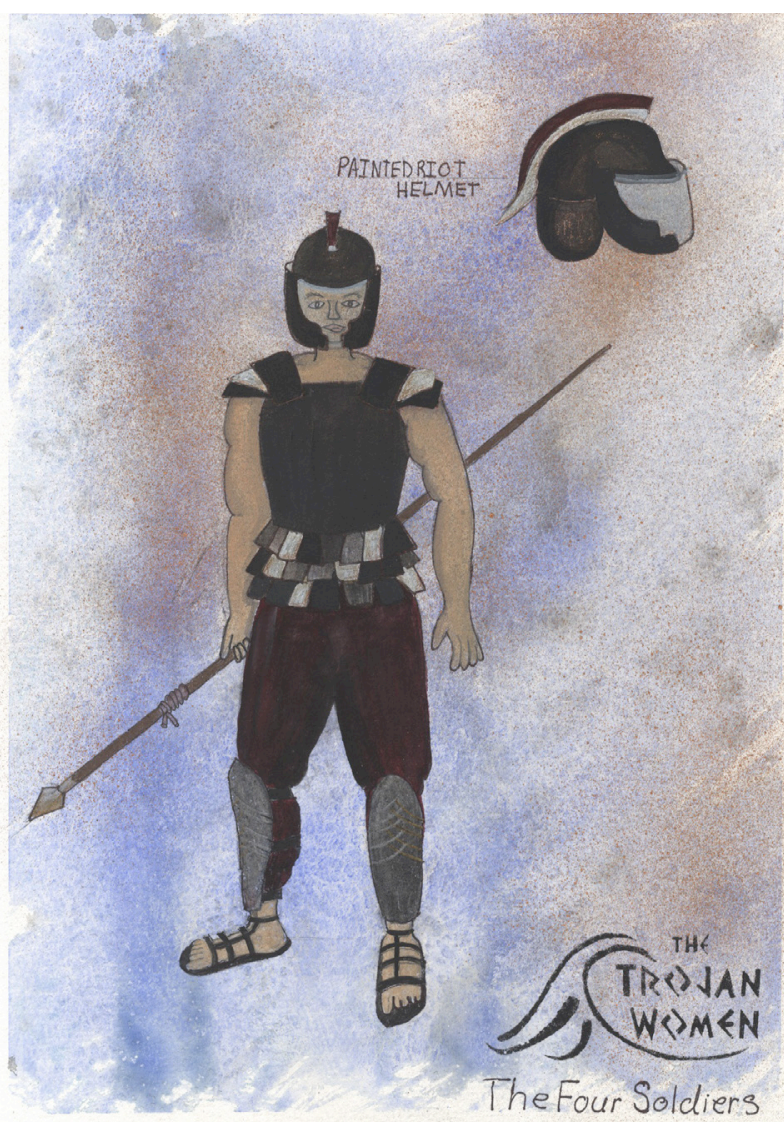

Figure 30: Final rendering for Soldiers.

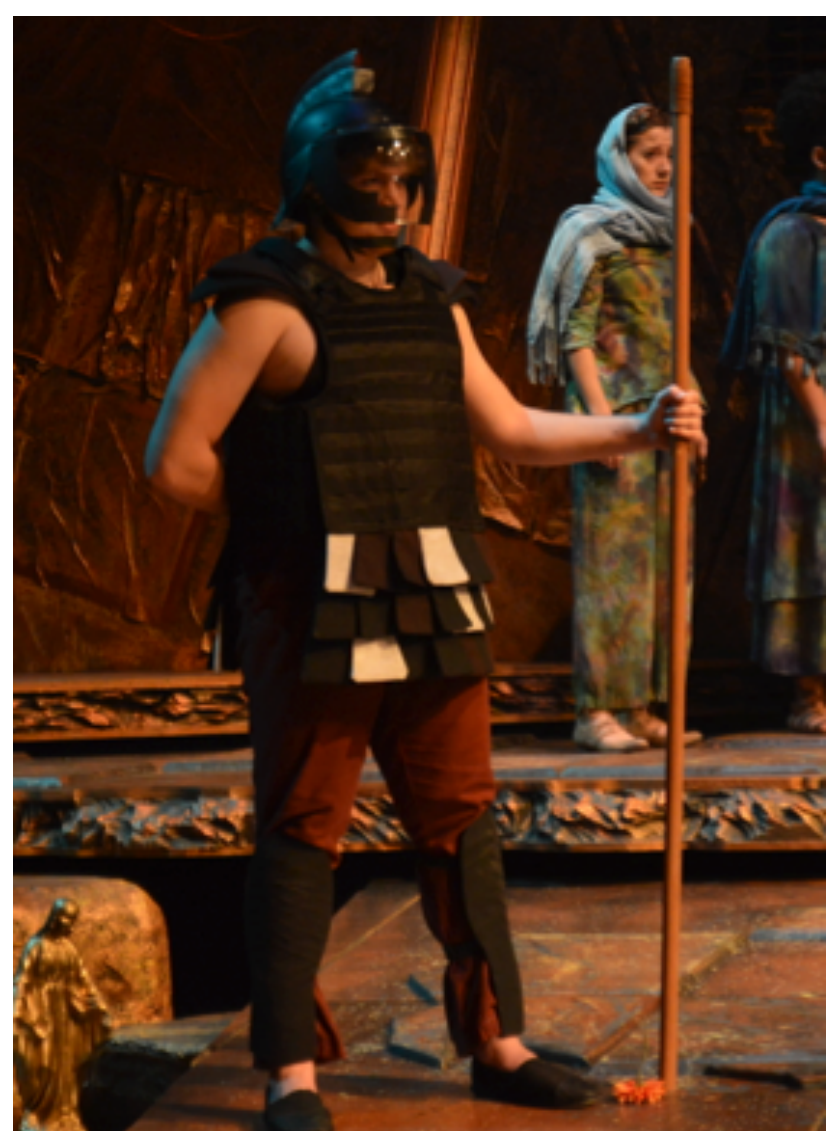

Figure 31: Produtcion photo of one Soldier (Matthew Clark).

The soldiers function as a male version of the chorus. They represented the low ranking

soldiers who had been doing the manual labor and fighting for the last ten years. There was much discussion on how to make them feel as if they were timeless like the women of the chorus.

Men's fashion and armor has changed since the Bronze Age. I knew from the start that I wanted to have the soldiers wearing pants to help convey a contemporary feeling since that is what most soldiers today wear. The Greeks typically fought naked or wearing only chitons. In working to bridge the gap between the two worlds, I dressed them in deep red linen pants. This color and material was the same used for the costumes of Menelaus and Talthybius connecting the soldiers. Their armor included a simulation of a linothorax (Figure 32), a type of upper body armor used 
by the ancient Greeks. For the production, their armor was made of a synthetic fiber canvas similar to a contemporary Kevlar vest (Figure 33) with an added skirt to mirror the silhouette of the linothorax.

Because the soldiers were meant to appear timeless like the chorus, they needed costume elements that acted in a similar way to the masks worn by the female chorus. Riot helmets (Figure 34) with face shields were added to mimic this effect. To again merge the ancient and contemporary, I added a crescent on the top and painted details on the face shield to mirror that of an ancient Greek helmet (Figure 35). These helmets were used as the actors played Menelaus's men but not when they were portraying contemporary soldiers at the opening of the production.

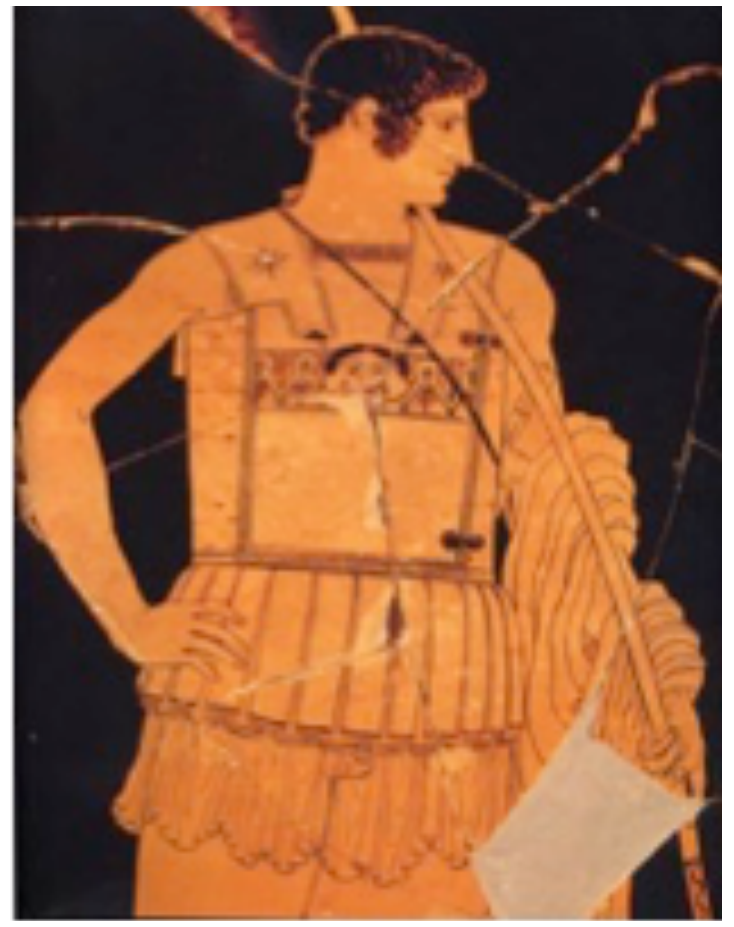

Figure 32: Research image of a linothorax.

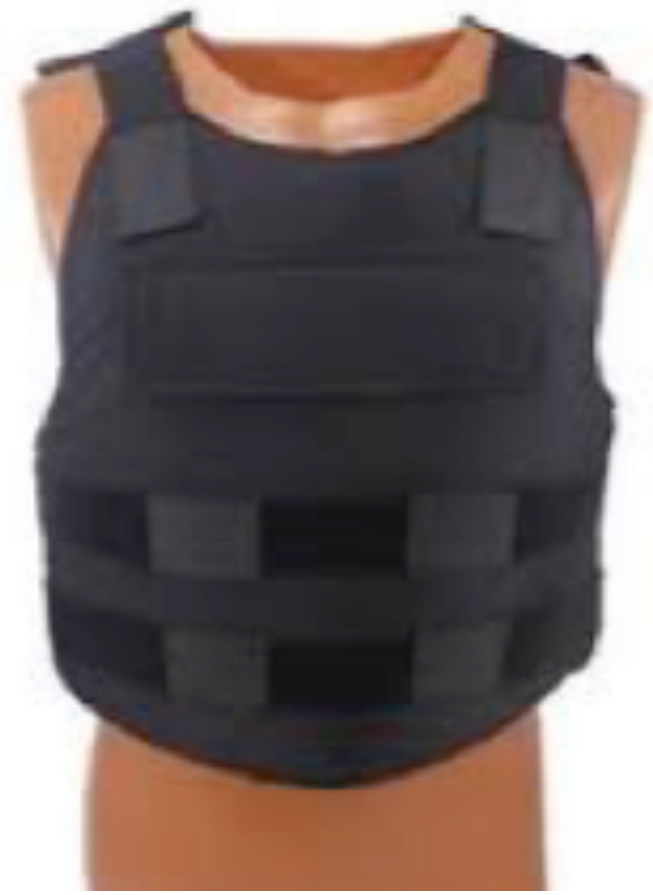

Figure 33: Research image of a 21st century Kevlar vest. 


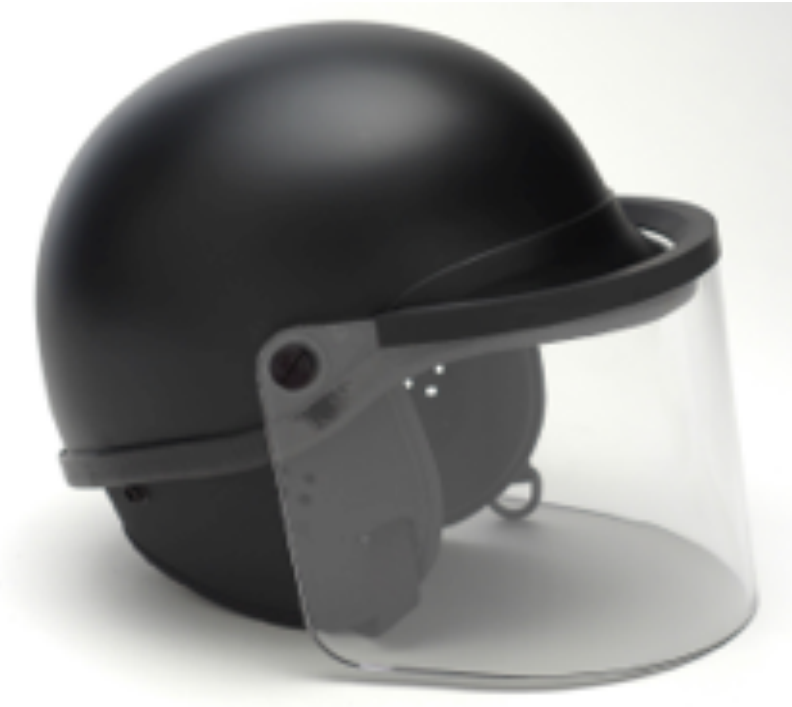

Figure 34: Research image of a 21 st century riot helmet.

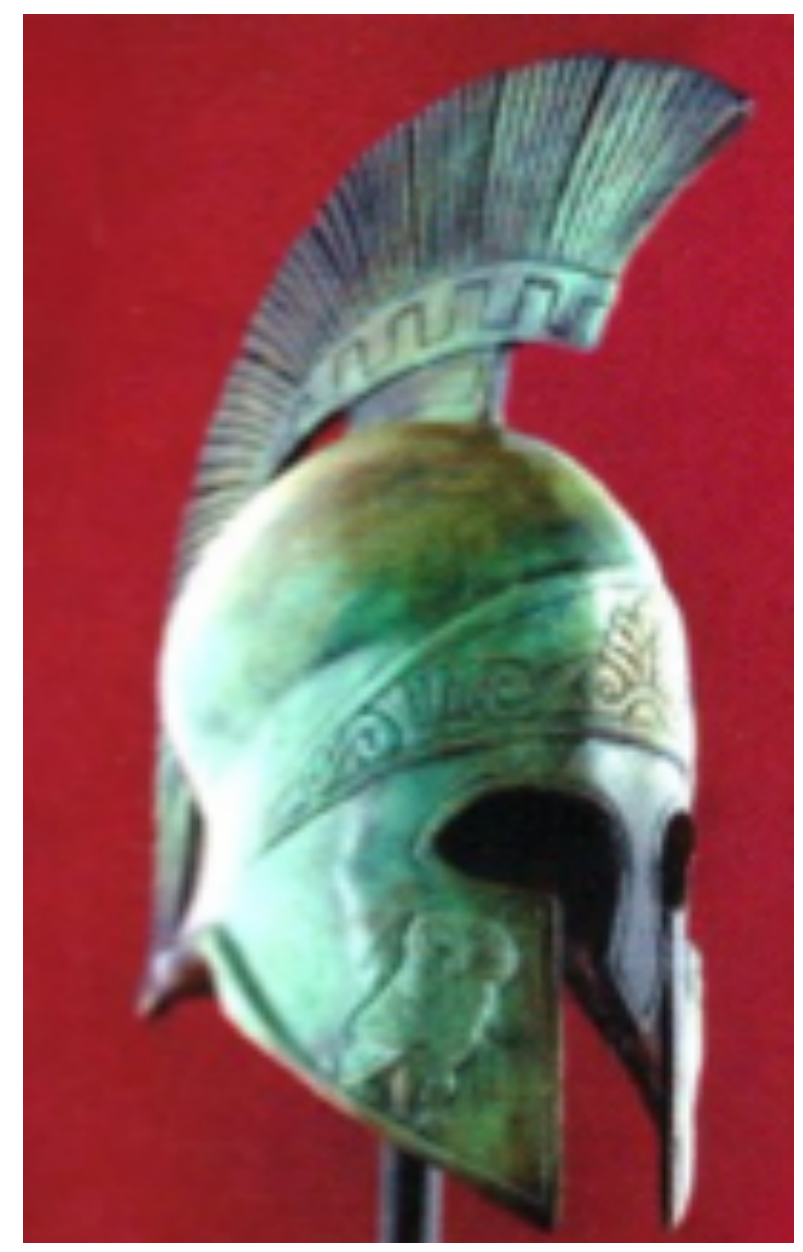

Figure 35: Research

image of a 5th century Greek helmet with cresent. 


\section{Hecuba}

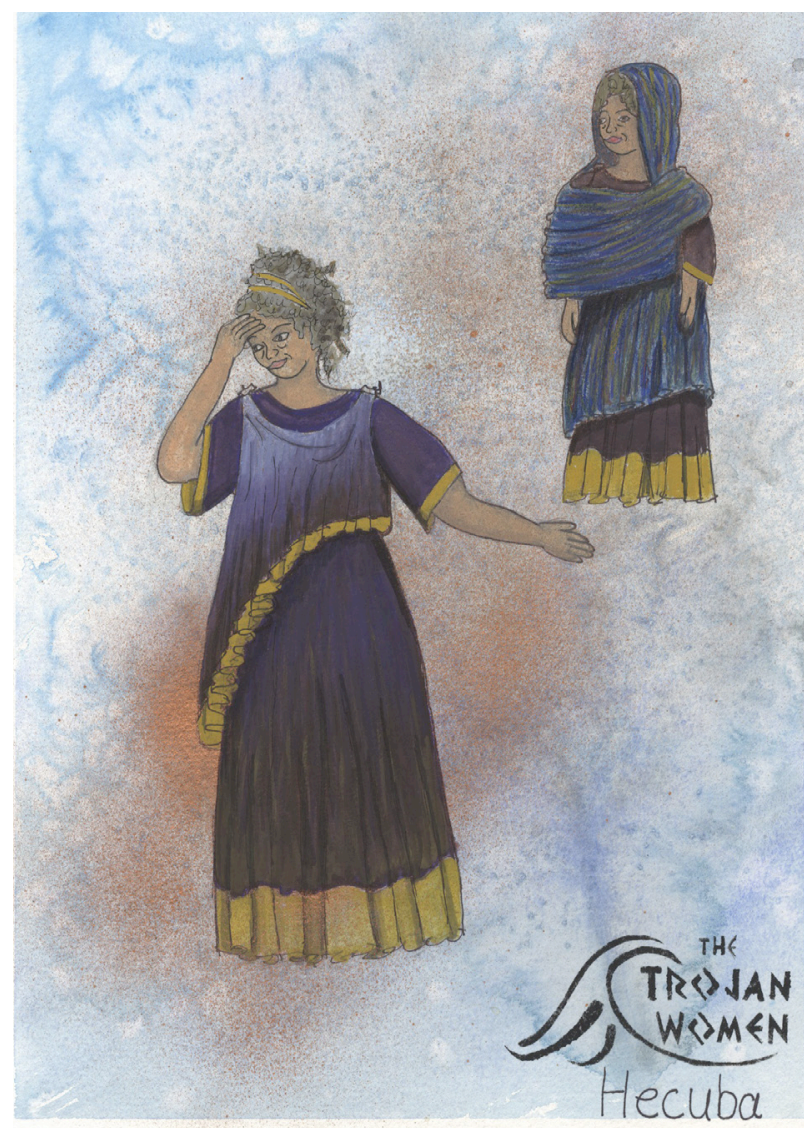

Figure 36: Final rendering for Heucba.

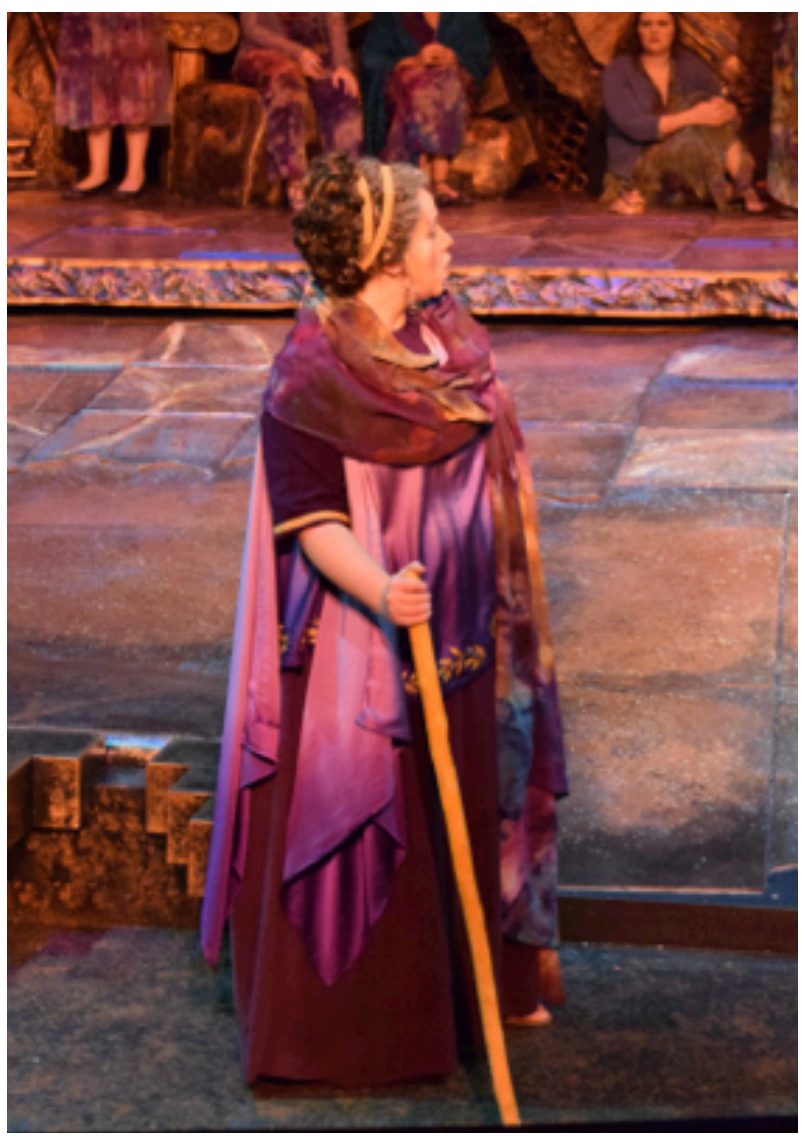

Figure 37: Production photo of Hecuba (Madeline Hintz).

Hecuba is the widowed Queen of Troy. Neoptolemus, the son of Achilles, killed her husband Priam during the final attack on Troy. Over the last ten years Priam and Hecuba had merely been figureheads of their city as they had become too old to handle the dealings of war. Throughout the script, Hecuba continually describes how her body is old and riddled with arthritis. The first time we hear her speak of herself she laments "Me with my grotesque body, the body of a bug that's slept on the ground? Me with my skinny flailing arms? My interesting arthritis" (MacEwen, 24).

My main inspiration for her was a wilting flower to illustrate her age (Figure 38). This evolved into her color palette, which consisted of purples, and gold, with browns creeping up 
from the ground. The color is draining out of the flower just as the life is draining from Hecuba. As the Queen she represented wealth and power, I wanted to show this by giving her an abundance of fabric compared to all the other women on stage. In this time, the amount of fabric you wore was a symbol of status, the more money you had the more fabric you could afford. I dressed her in a purple Doric peplos (Figure 39) layered with an ombre purple top layer, which was trimmed in gold. She enters wearing a diplax (Figure 40) dyed with a similar technique as the chorus costumes. I used this color association because though she is being treated like the rest of the women, underneath she remains a queen.

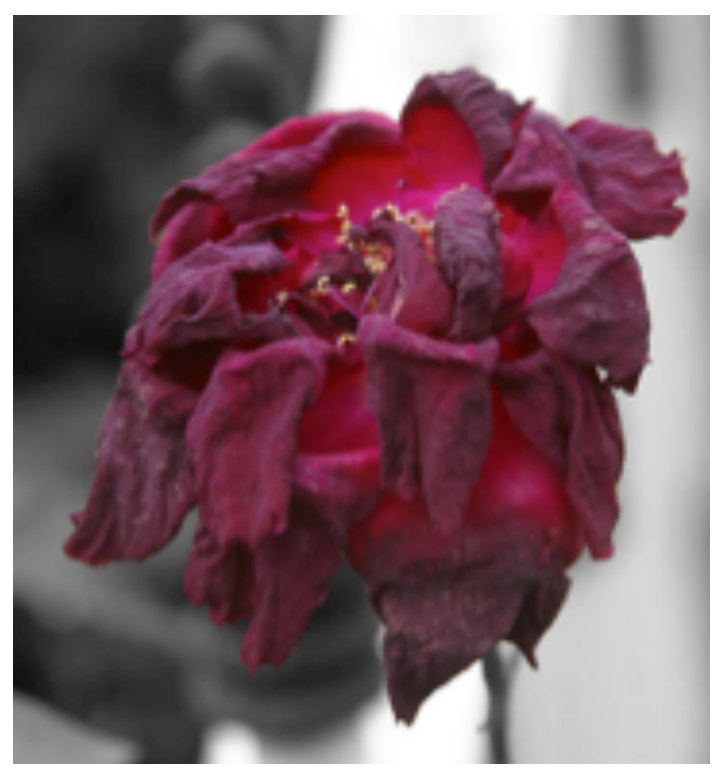

Figure 38: Inspiration image for Hecuba of a wiliting flower.

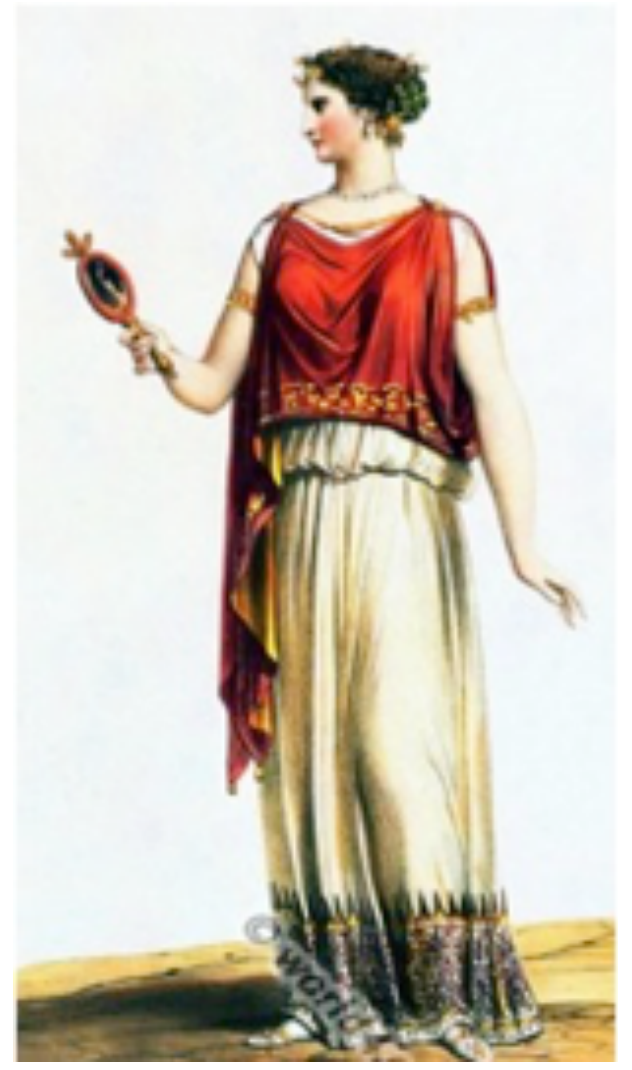

Figure 39: Research image for Hecuba's Doric peplos.

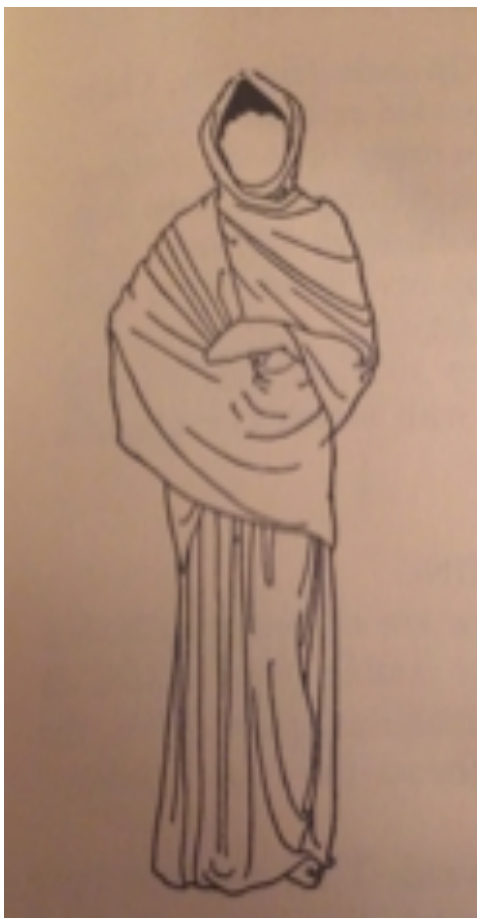

Figure 40: Research image of a diplax. 


\section{Cassandra}

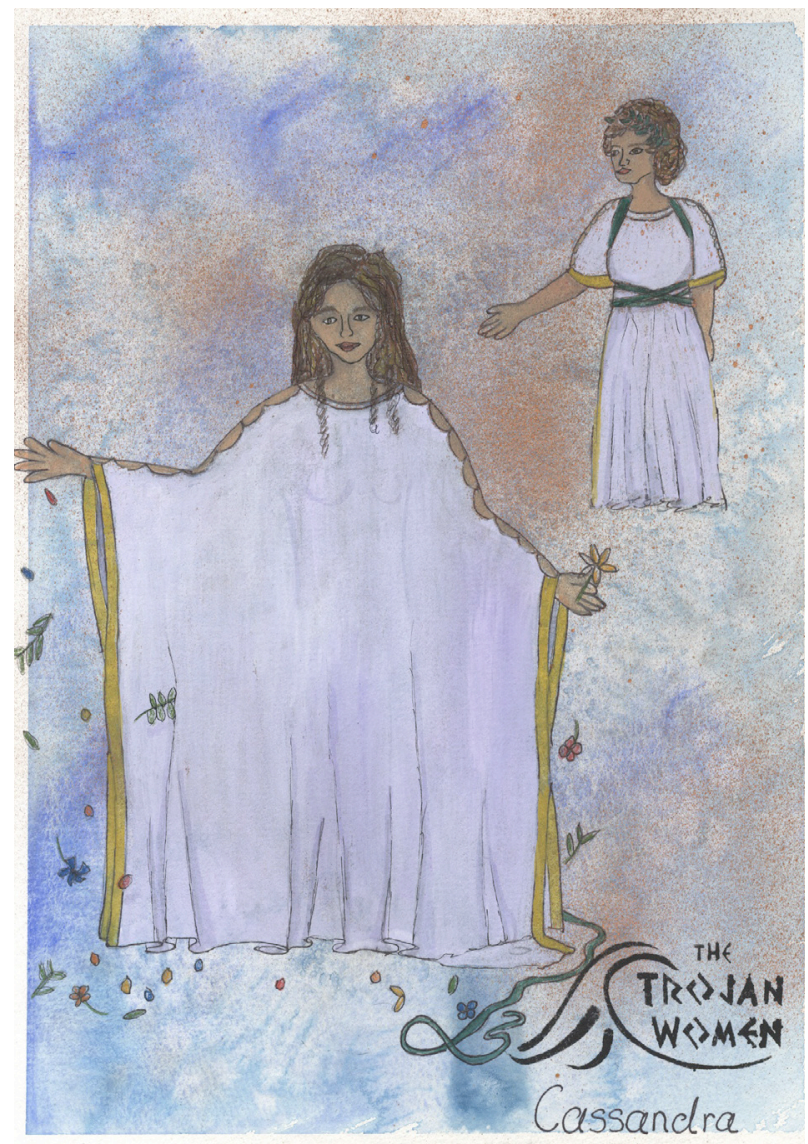

Figure 41: Final rendering for Cassandra.

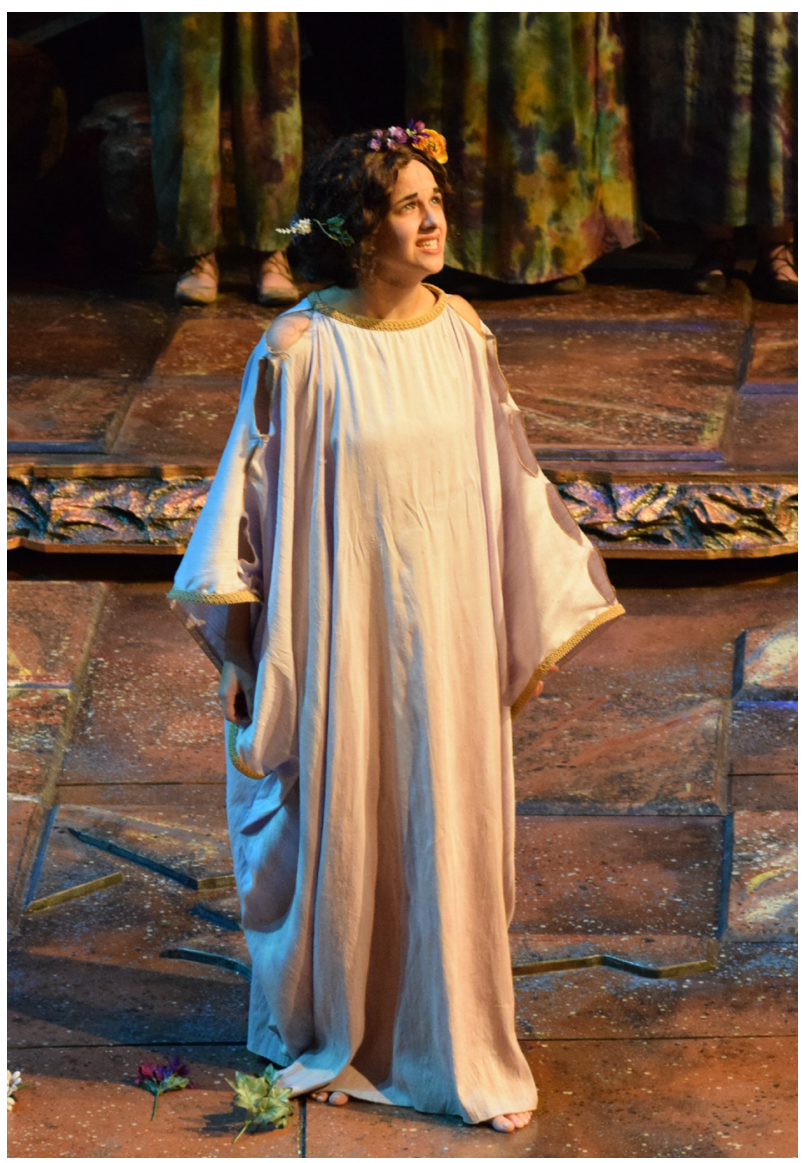

Figure 42: Production photo of Cassandra (Rachel Moore).

Cassandra is a scared virgin, daughter to Hecuba, and priestess to the god Apollo. She can hear the voices of the gods who tell her the future. Yet her curse is that no human believes her and they think she is mad. The chorus continually recites the line, "Leave her alone; she's mad" in reference to Cassandra.

I felt it was essential to show the transformation her character goes through with her costume. I dressed her in an Ionic chiton, which provided the options of a bound (Figure 43) and unbound (Figure 44) silhouette. The length contributed to the appearance that she was drifting instead of walking. The fabric her costume was created from was a raw silk with slubs, a texture 
created in the weaving process. This flowed beautifully around her body and the rough texture of the silk helped give her a more organic feeling.

There are many theories as to how Cassandra received her gift of prophecy, one being that temple serpents, which symbolize wisdom, licked her ears clean so that she could hear the future (Figure 45). I chose to make her belt green with a snake-like texture to visually represent this connection. Among the flowers she wears a laurel wreath showing her connection to Apollo. The laurel wreath is a large part of Apollo's iconography.

When she first enters, Cassandra is still dressed as a priestess in her lavender chiton with a green cord tied around her body and flowers in her hair, as mentioned in the script. She wore light lavender that was almost white, to keep her in the Trojan color palette but also to show her purity as a holy virgin. During the scene where she explains her revelation she unbinds her
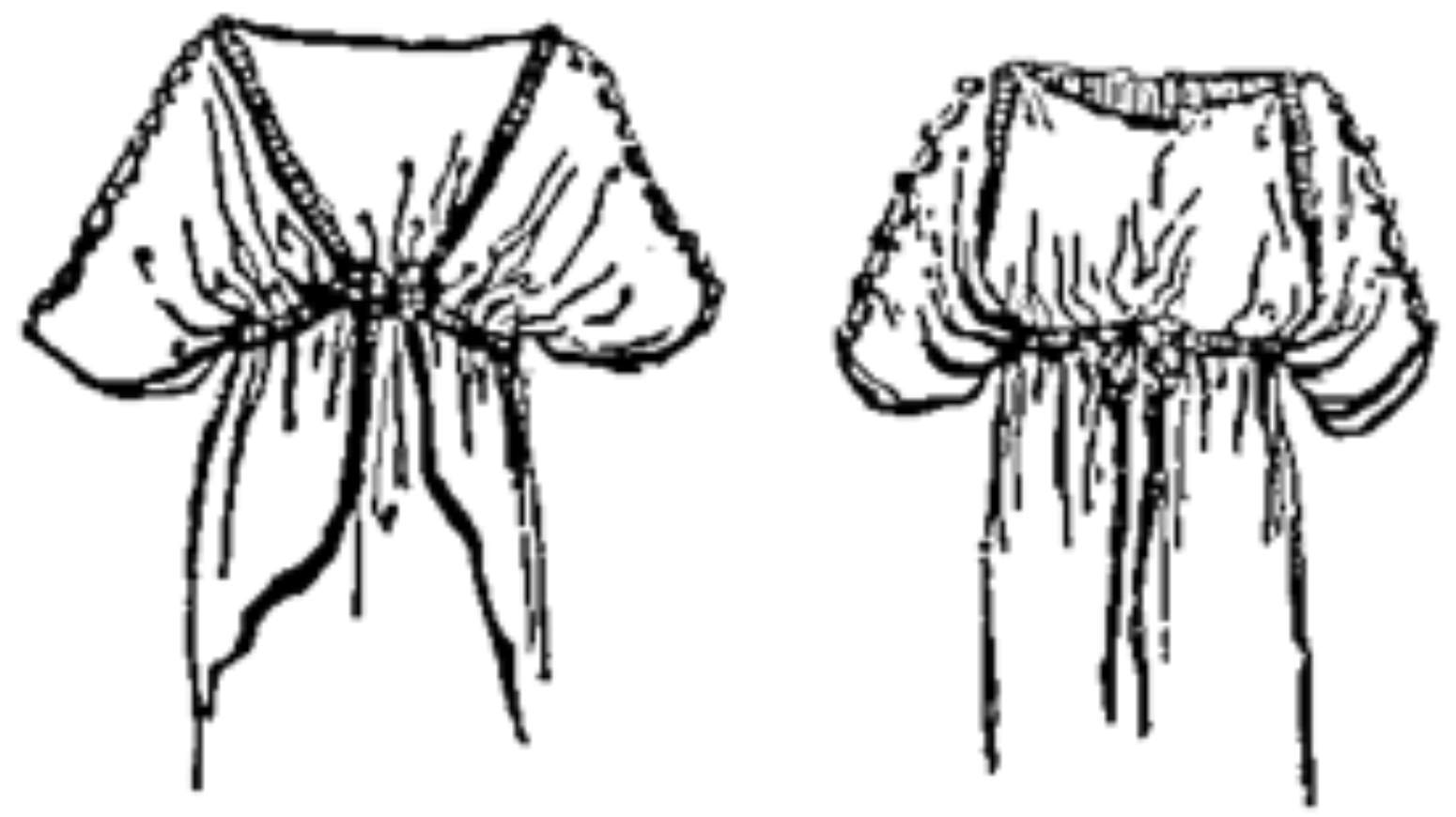

Figure 43: Research image of bound Ionic chiton. 
belt freeing her chiton allowing it to flow

around her body. Cassandra then

transforms into a sexual character, in

contrast to the character of Helen. All

of Helen's worth and power is based on

being sexually attractive to men; thus, she

is dressed scantily. In contrast to Helen,

Cassandra's chiton drapes around her

body showing her figure without revealing

skin.

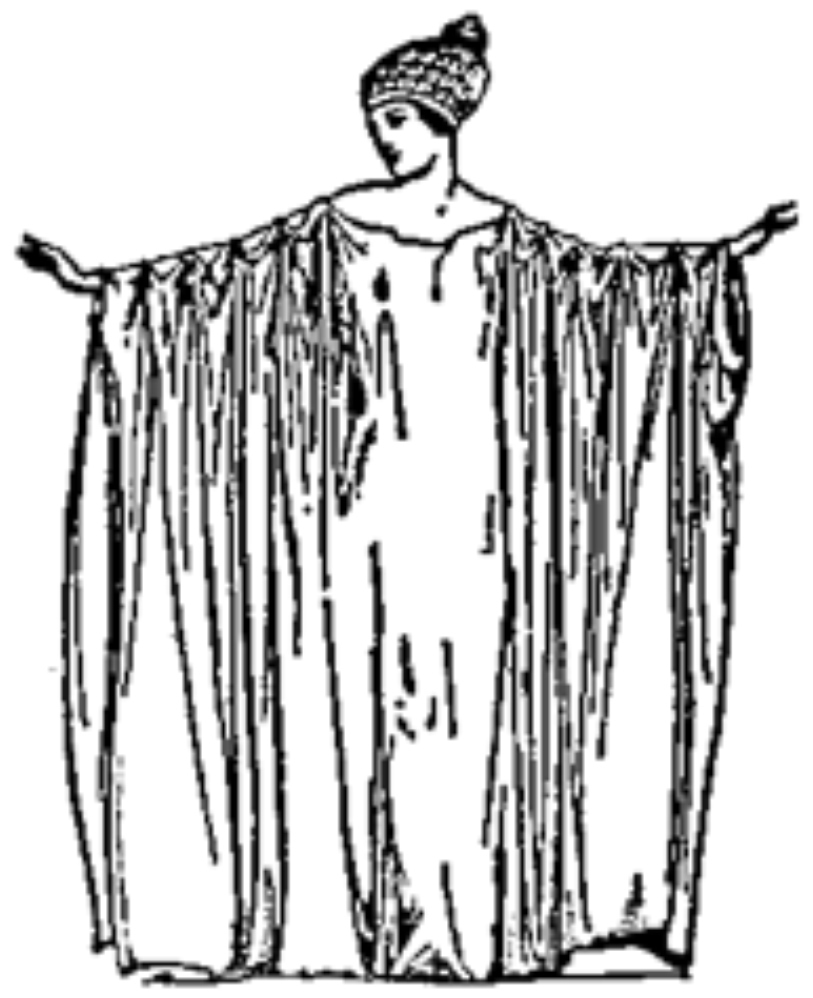

Figure 44: Research image of unbound Ionic chiton.

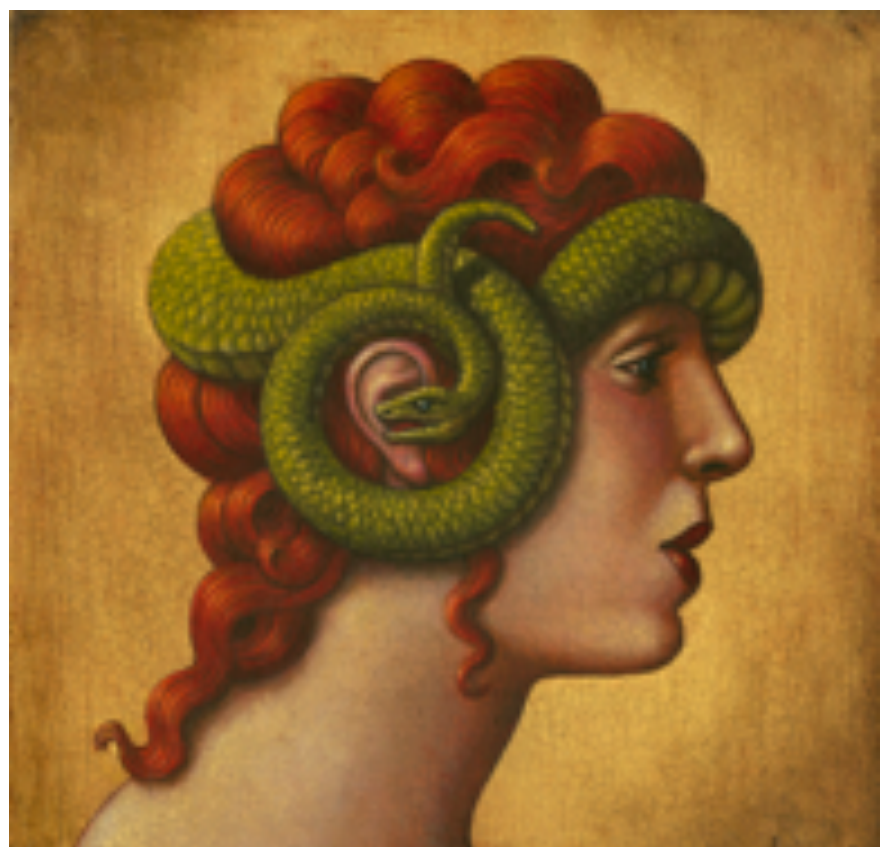

Figure 45: Inspiration image of Cassandra and snakes. 


\section{Talthybius}

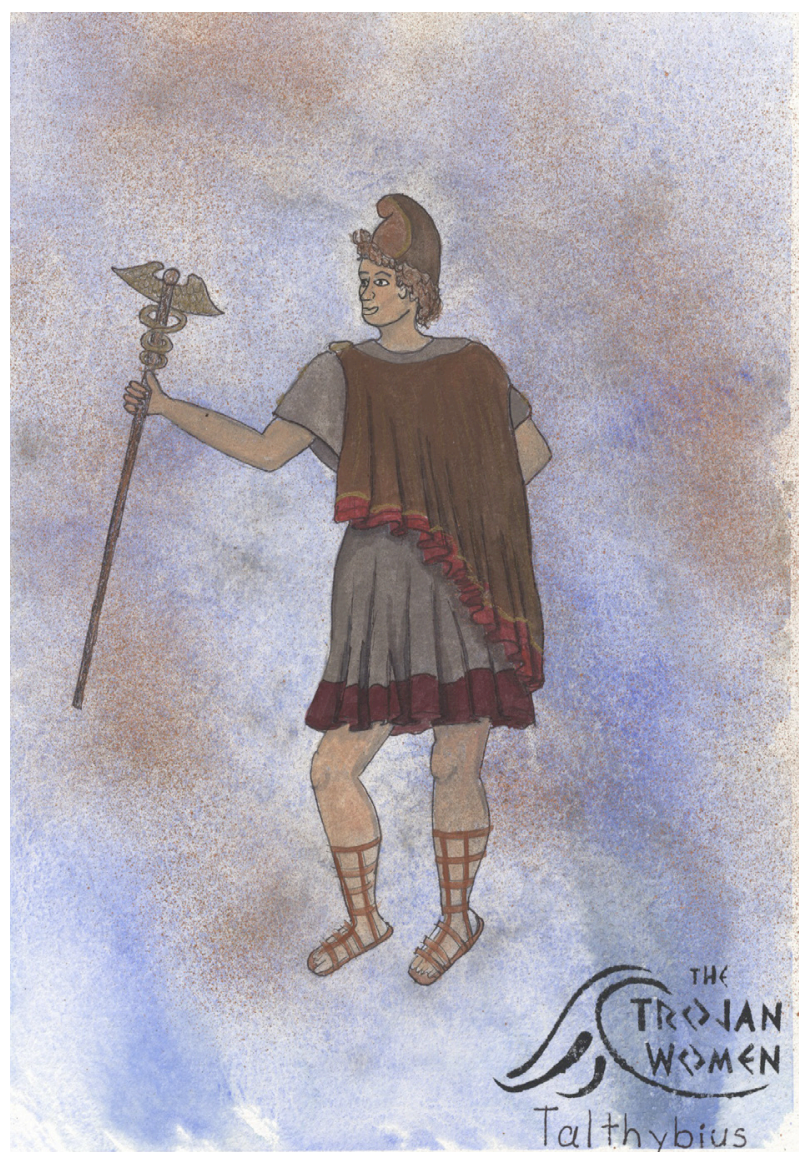

Figure 46: Final rendering for Talthybius.

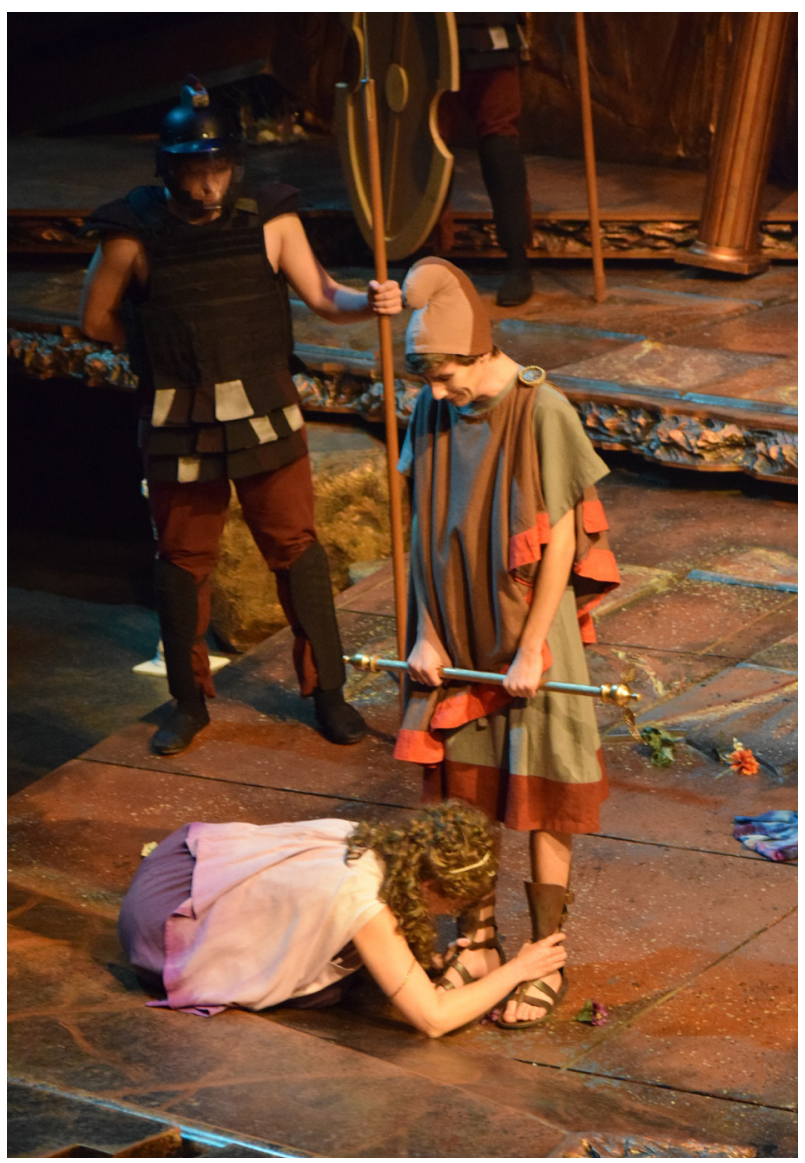

Figure 47: Production photo of Talthybius (Zach Powers).

Talthybius feels the most relatable of the Greek characters; he expresses sympathy rather than anger, like Menelaus. He is a messenger, not a soldier, and was likely a young boy when he came to Troy. He acts with authority but has a compassionate side, which shows in the way he tells Andromache her son's death will be quick.

Since he is sympathetic, I wanted to keep him in neutral colors. I chose to dress him in warmer grays. I originally contemplated dressing him in browns and earth tones but was concerned his colors would be too similar to that of the set. Both his chiton and chlamys are trimmed in red connecting him to Menelaus and the Greeks. Because of his status as a messenger his look is 
similar to that of Hermes (Figure 48), messenger to the gods.

Atop his head he wears a Phrygian bonnet (Figure 49). This gave him a similar silhouette to Menelaus but in a softer manner.

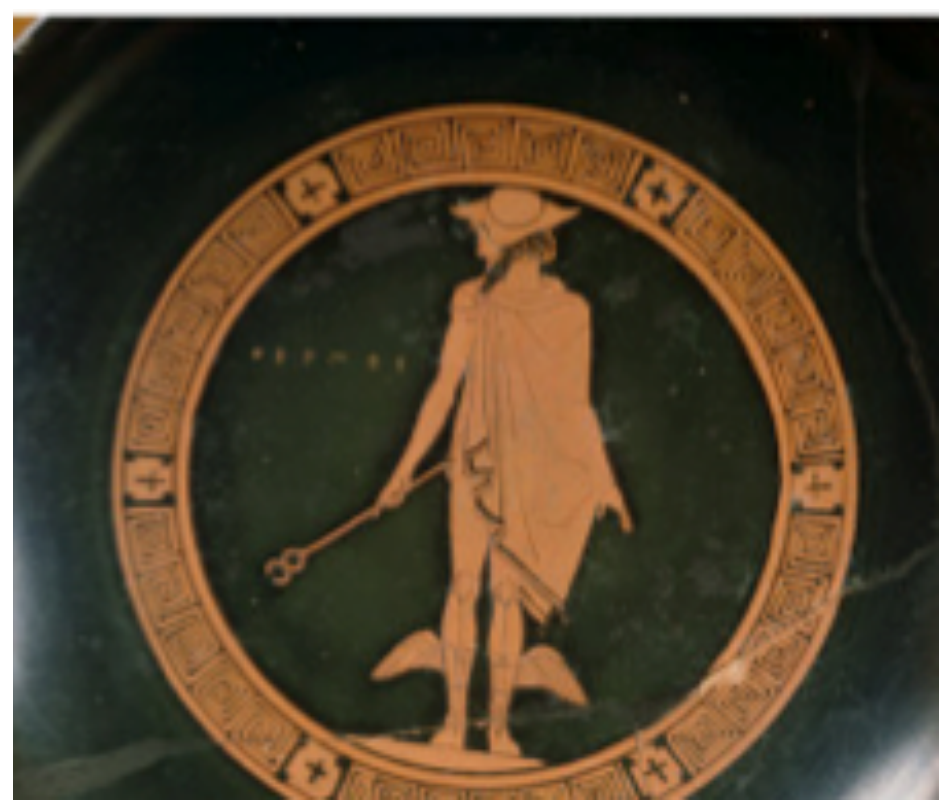

Figure 48: Research image of Hermes.

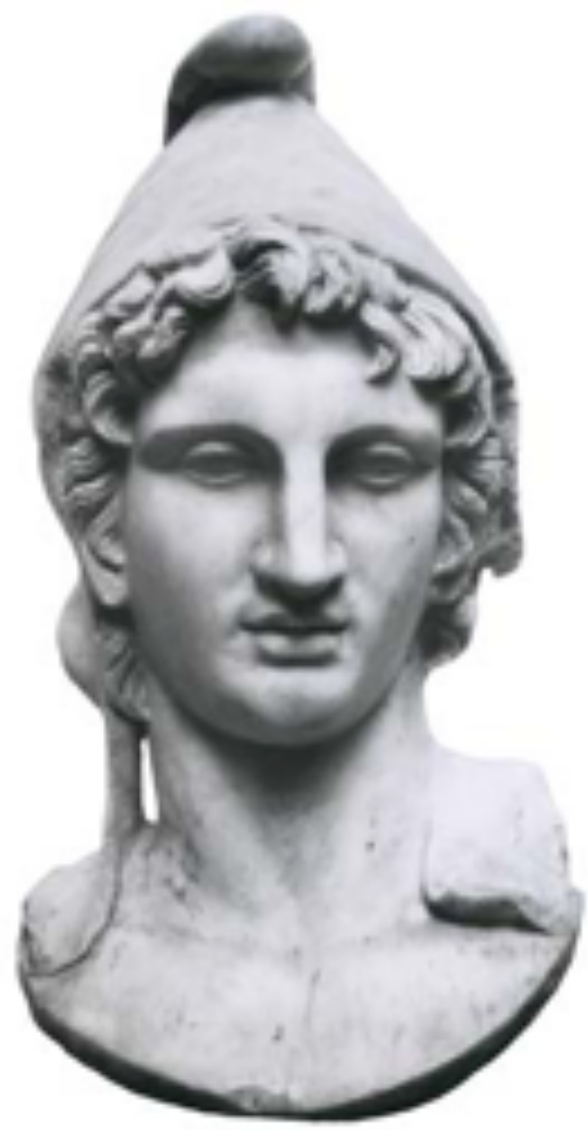

Figure 49: Research image of Phrygian bonnet. 


\section{Andromache}

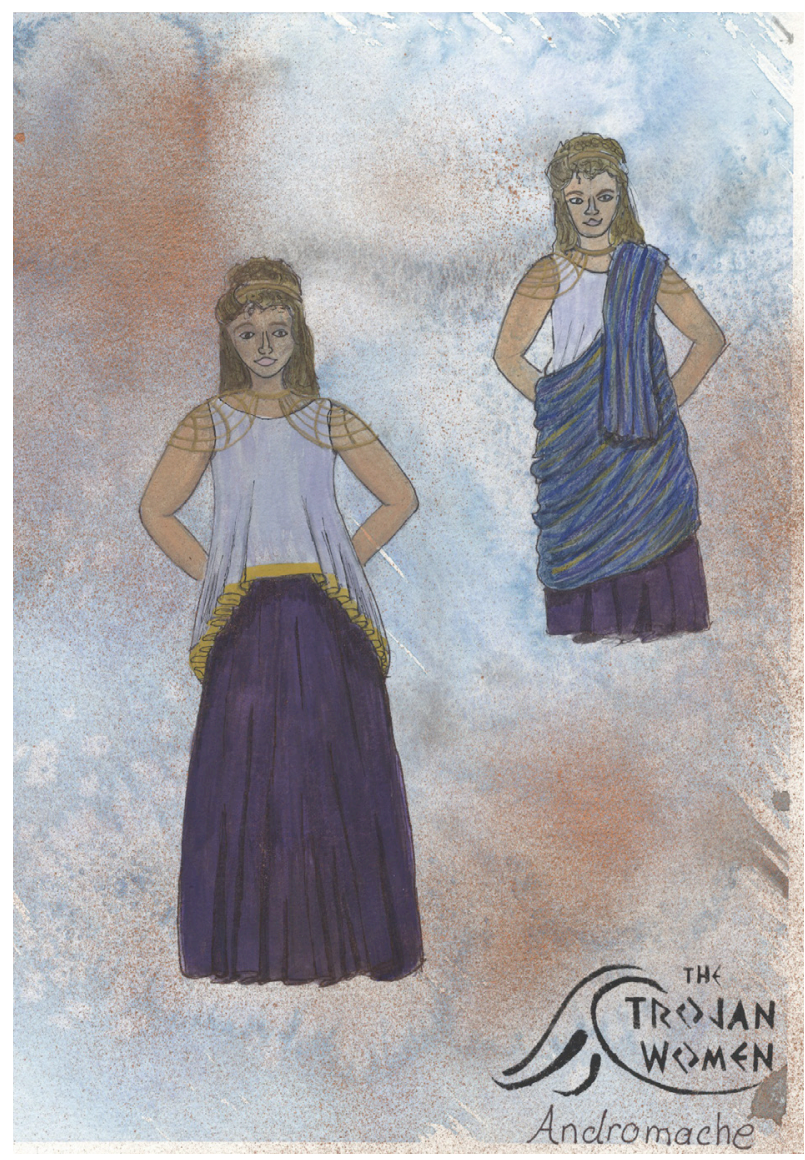

Figure 50: Final rendering for Andromache.

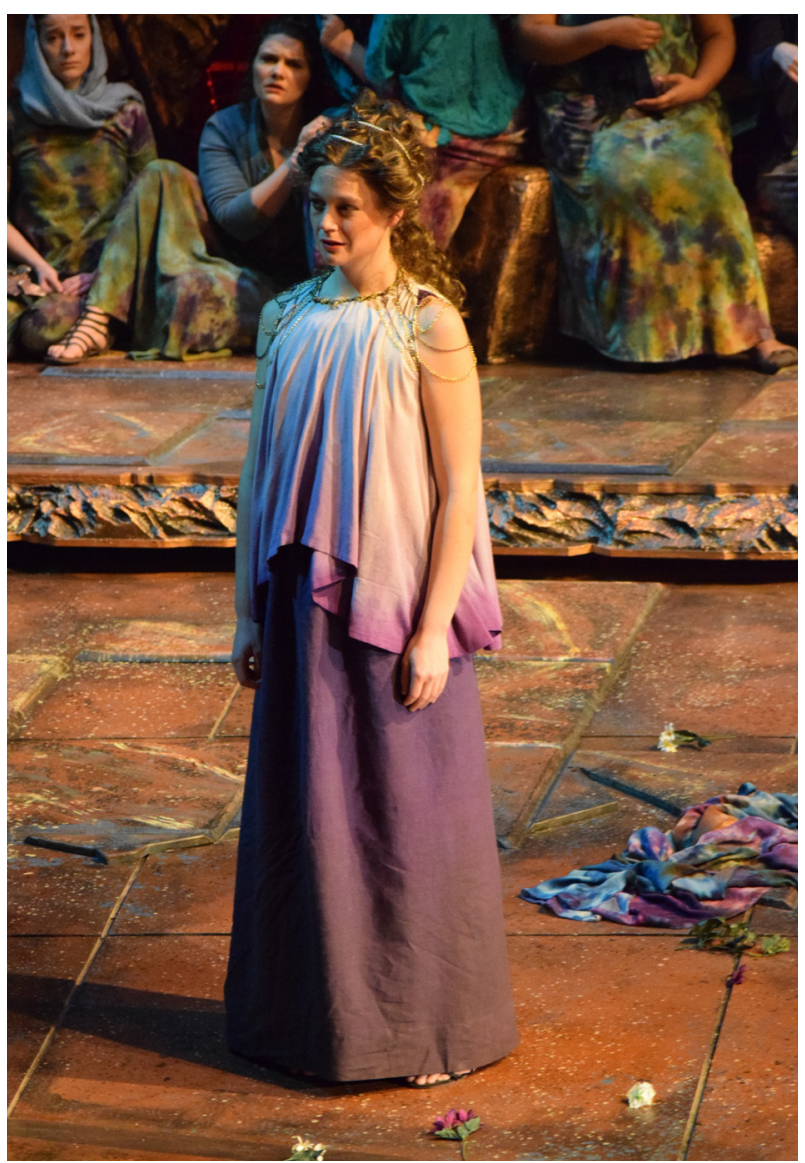

Figure 51: Production photo of Andromache (Cassandra Hackbart).

Andromache is a princess and a soldier's wife. For the past ten years she stood by her

husband, Hector, as he commanded the army of Troy. With his death, all that remains is her son.

As acting queen, Andromache is dressed similarly to Hecuba. She wears a deep purple

Doric peplos (Figure 52) with a light lavender top layer. Her palette is much richer than Hecuba because she is still in the prime of her life. Additionally, she wears gold jewelry draped around her shoulders (Figure 53) with the appearance of armor helping to further illustrate her role as a military wife. Like Hecuba she enters wearing a diplax dyed to match with the chorus women. 
This helps to connect her to the chorus but when she later removes the diplax she reveals herself as a Trojan royal.

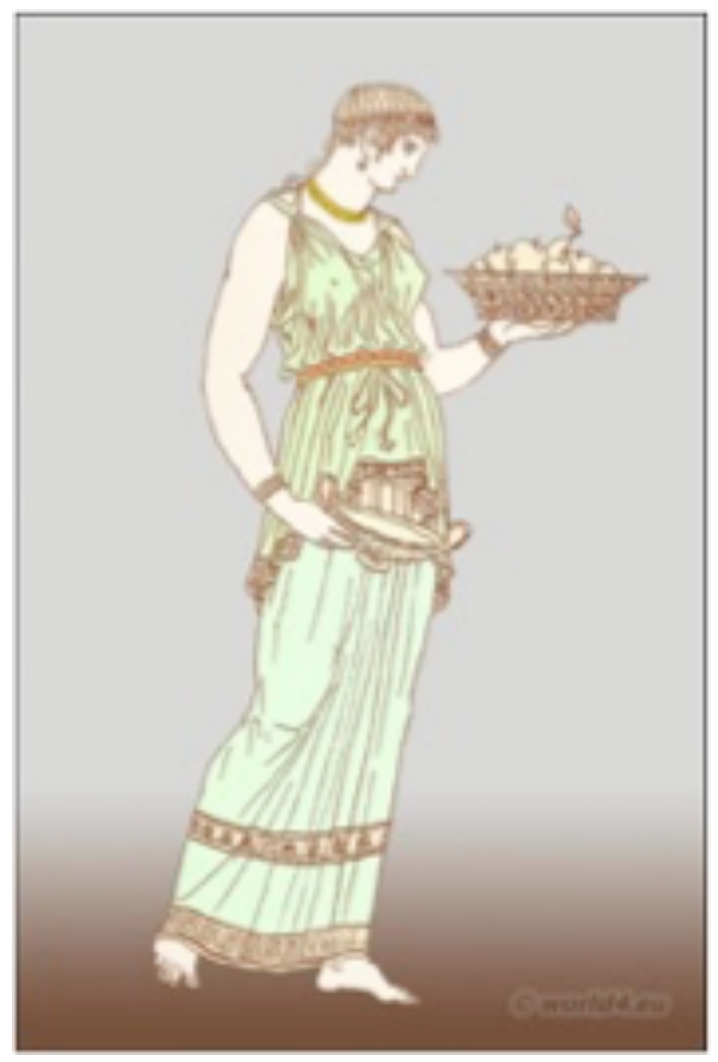

Figure 52: Research image of Doric peplos.

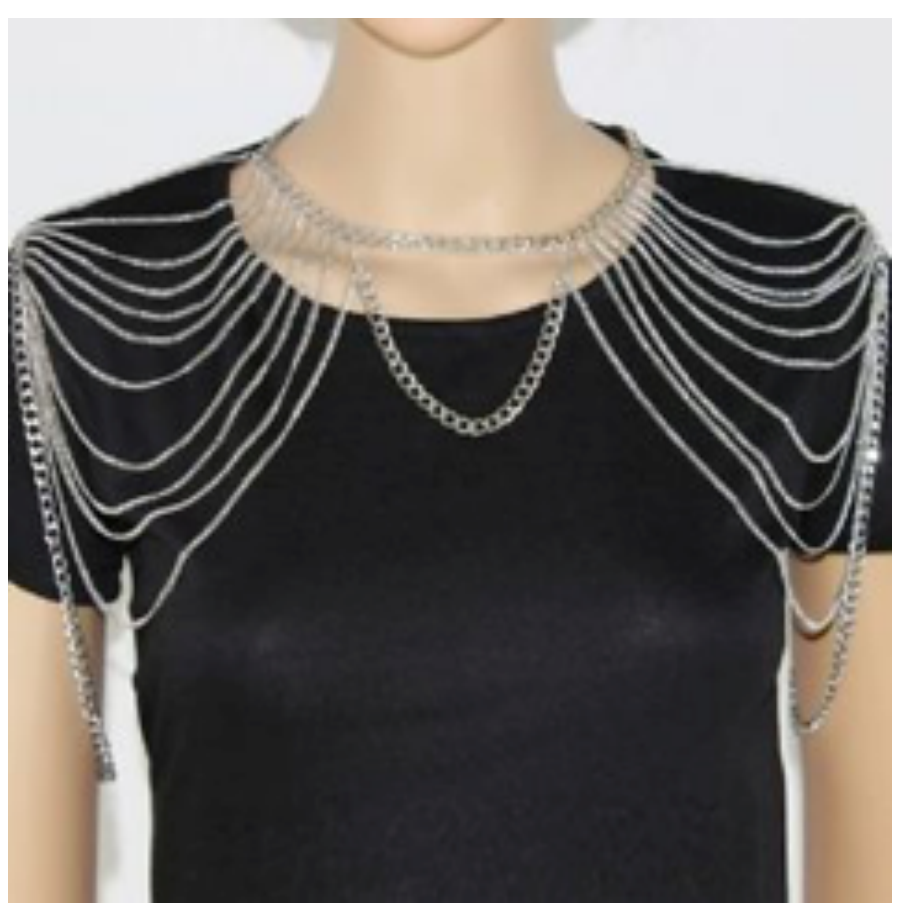

Figure 53: Research image of sholder jewelry. 


\section{Child}

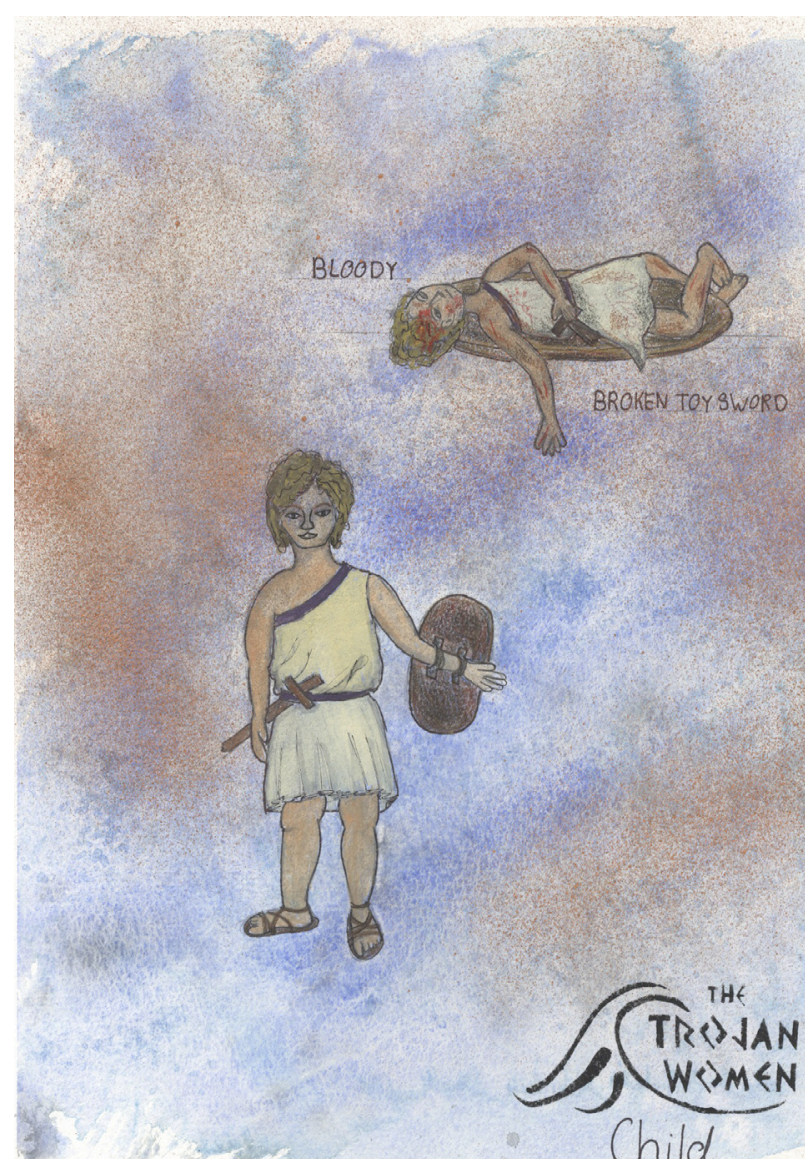

Figure 54: Final rendering of Child.

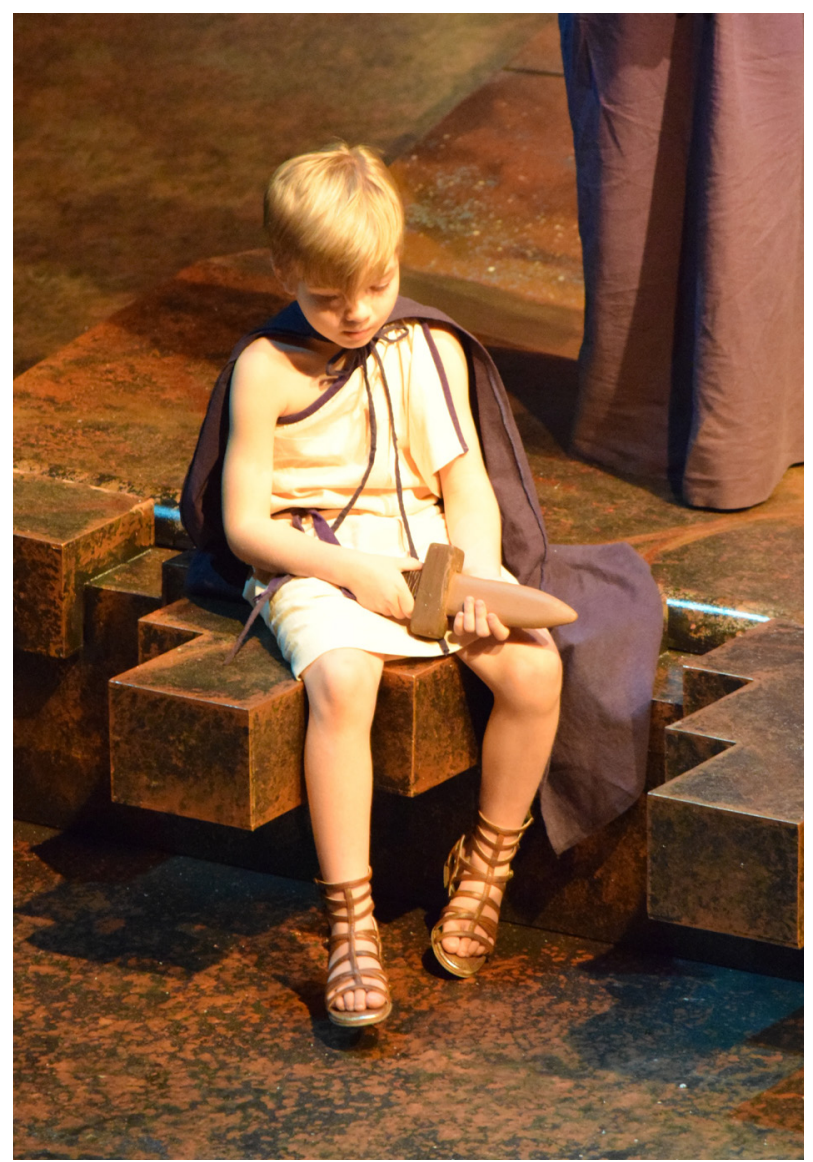

Figure 55: Production photo of Child (Eben Mugrage).

The young, innocent son of Hector and Andromache is perhaps the most unfortunate victim of the war. The Greeks take him away to be killed because they fear he will grow up and avenge his father's death.

He wears a short, light yellow chiton and deep purple cloak. His cloak matches the color of his mother's chiton (Figure 56). The light yellow color of his chiton symbolizes his youth and innocence.

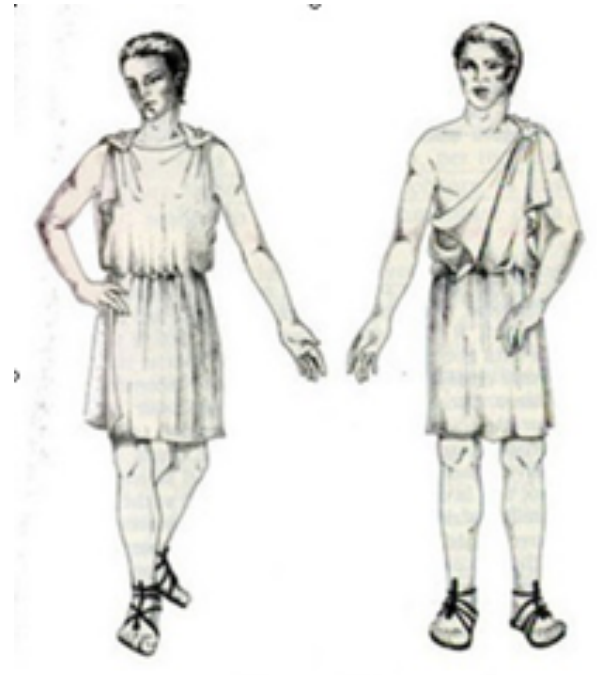

Figure 56: Reseach image of one-sholdered chiton. 


\section{Helen}

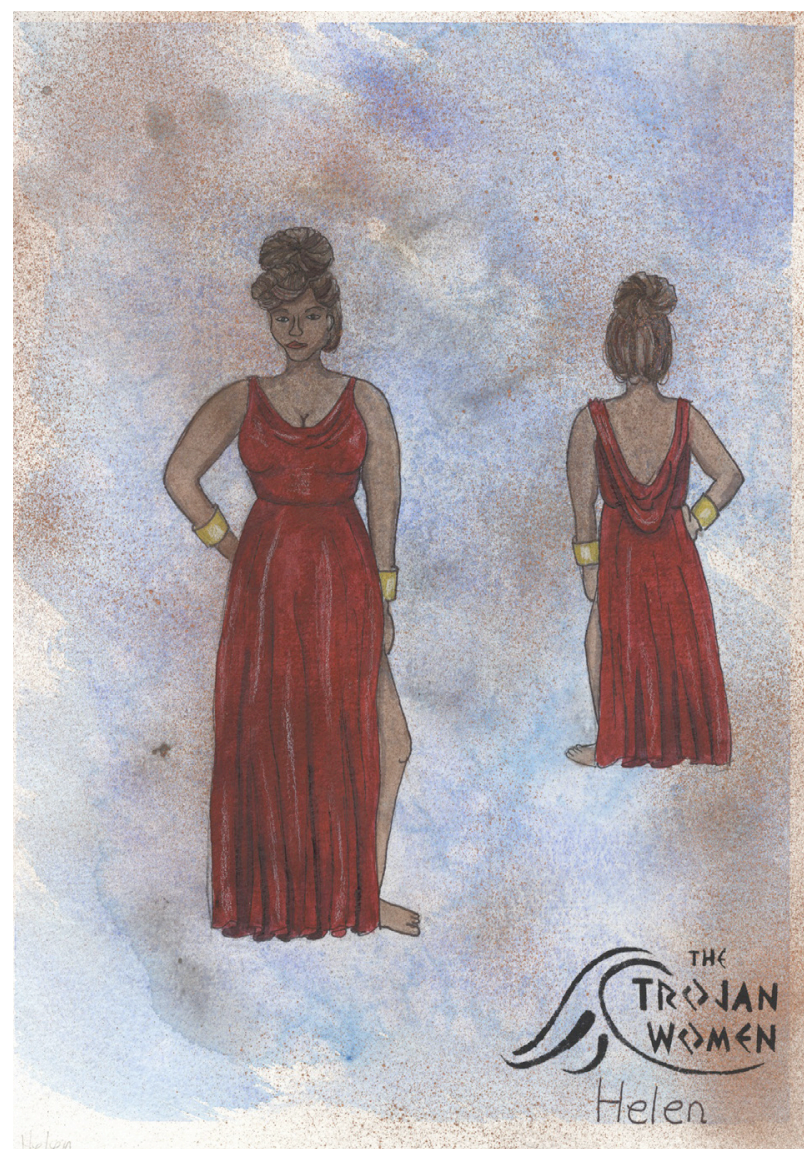

Figure 57: Final Rendering for Helen.

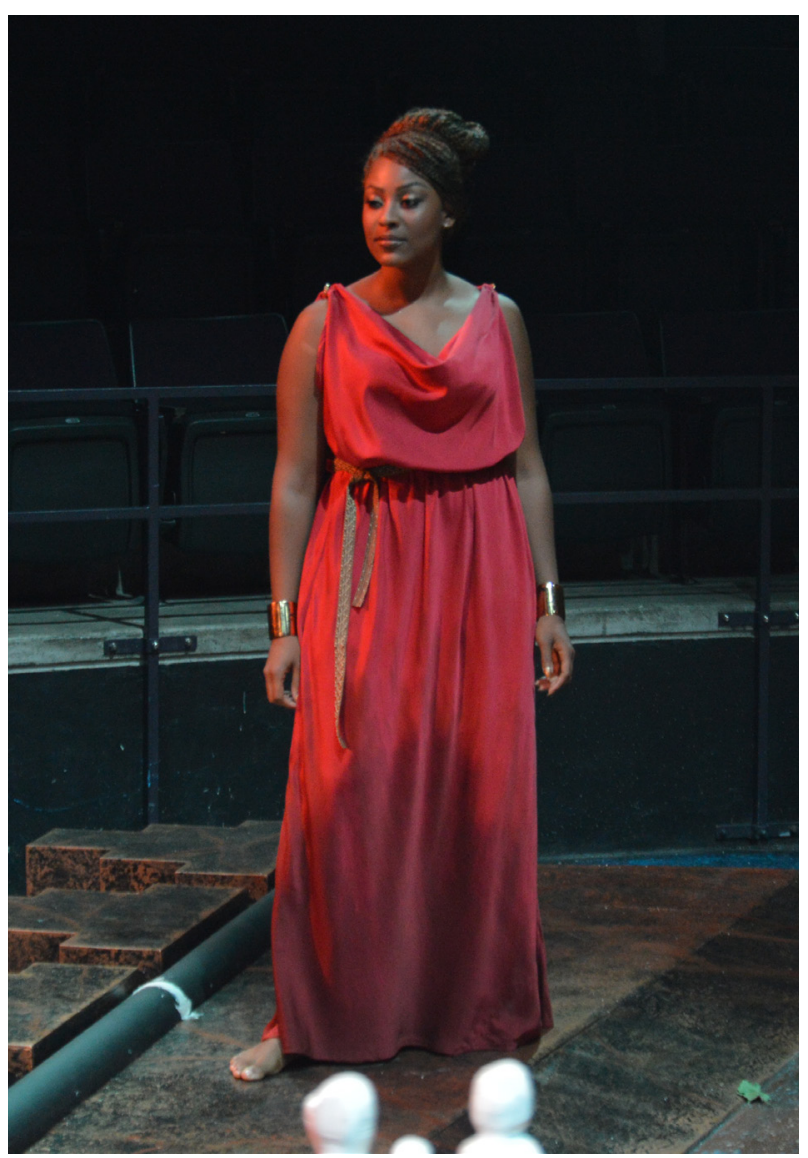

Figure 58: Production photo of Helen (Christin Wright).

Helen ran away with Paris to Troy deserting her husband, Menelaus, causing the start of

the war. Her story throughout Greek mythology is complex. Although she is associated with the cause of the war, many believe she was a political excuse to invade. There are also several theories as to whether she goes willingly or not with Paris to Troy. I chose to think of her in a middle ground because no matter how she got there she is ready to use her beauty to save her life.

Because she is foreign to Troy, I wanted to make sure she stood out next to all the other women. She is sexy and has been primping in her hut the entire show waiting for Menelaus to 
arrive. While the other women are frazzled, Helen is ready to seduce Menelaus to save her life. Her red chiton evokes love and seduction while also tying her to the rest of the Greeks. The low back and high slit in her silk charmeuse chiton leave little to the imagination. She wears a gold cuff on each wrist showing her status as royalty but also symbolic of shackles. Additionally the bottom of her dress has the same dripping brown detail as Hecuba, Andromache and Cassandra showing she is also a victim. I also wanted a high slit in the side of her dress, as Hecuba mentions "a slit up to your ass." The high slit also allowed for greater movement which was essential since her blocking called for her to fall on the floor several times while begging for her life.
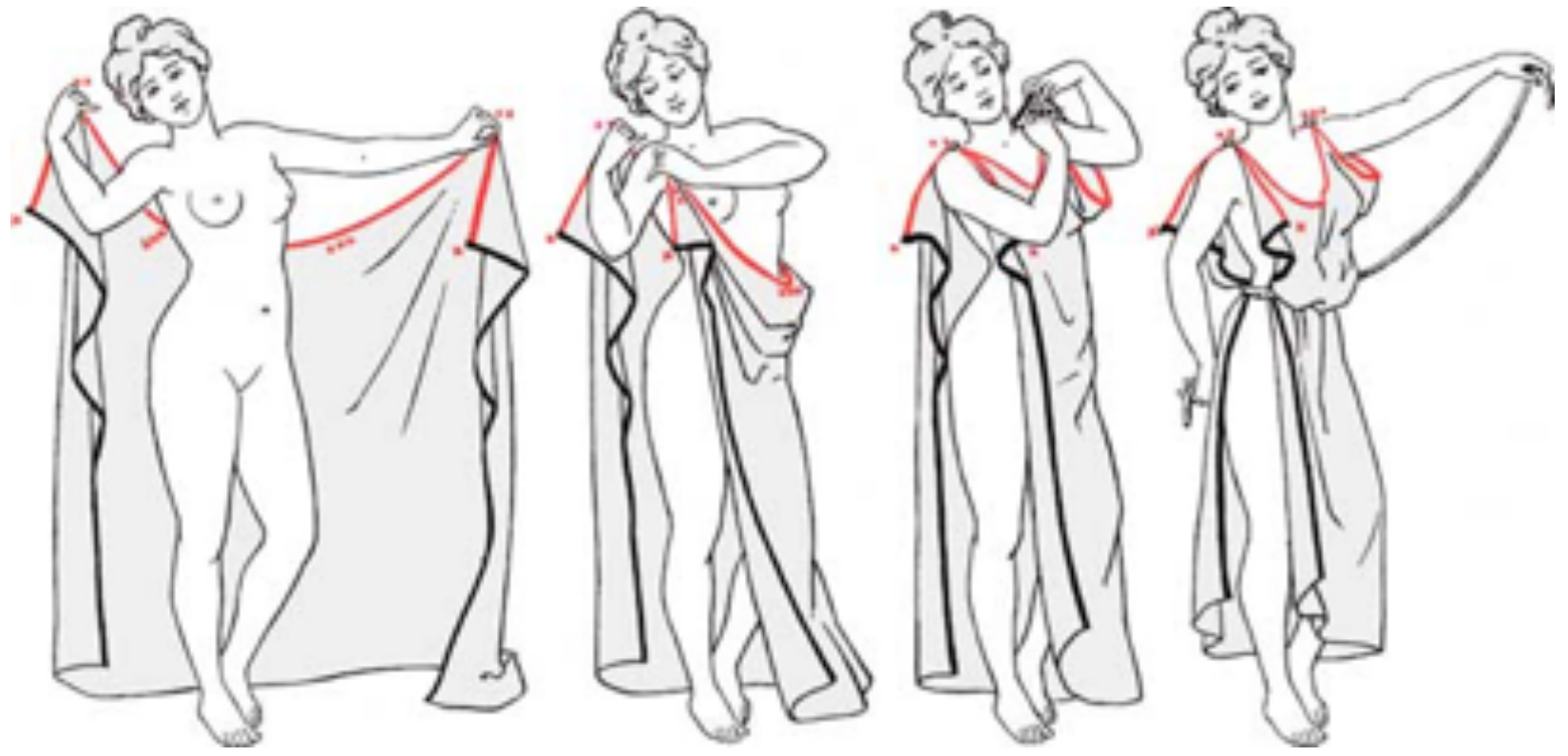

Figure 59: Research image of how to tie a chiton. 


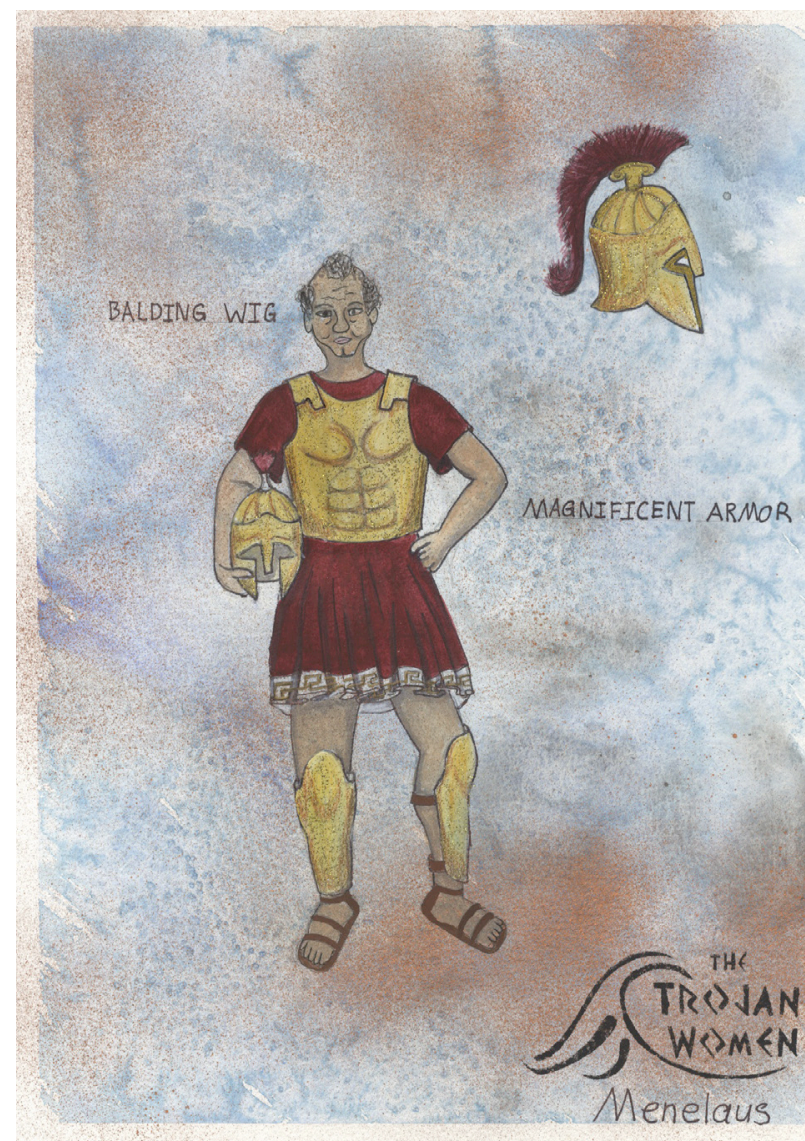

Figure 60: Final Rendering for Menelaus.

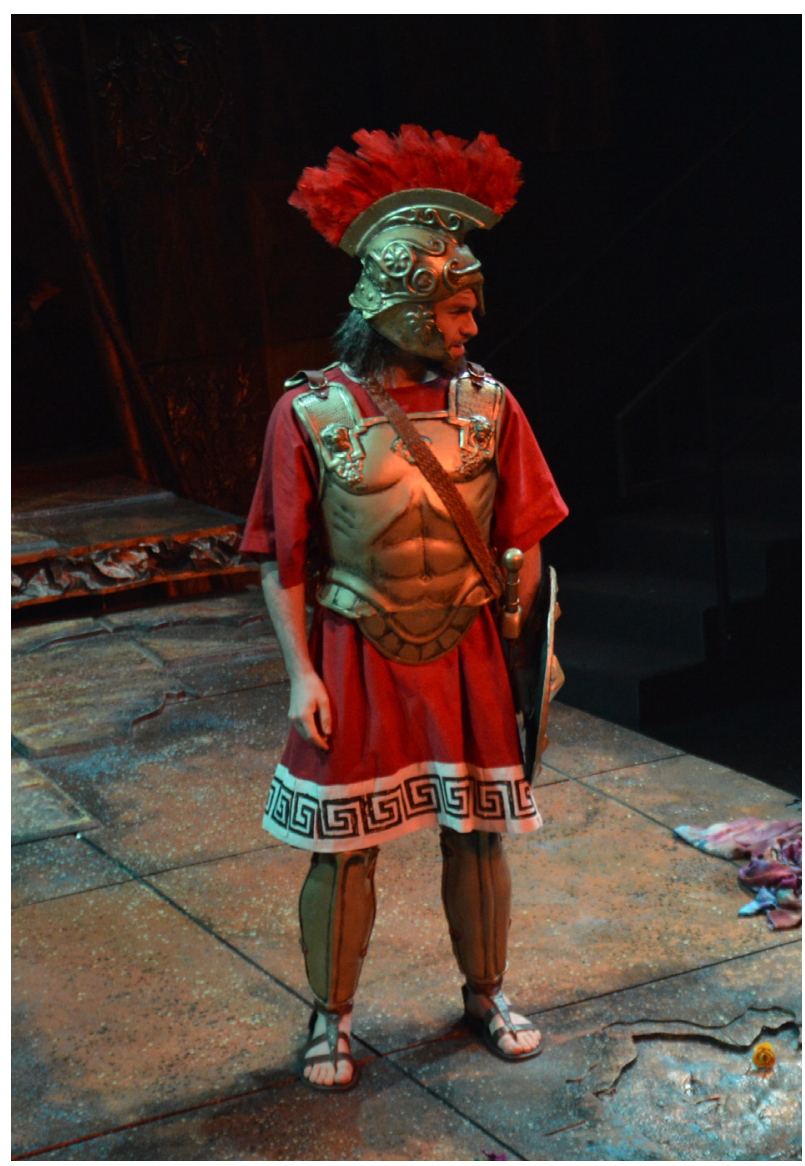

Figure 61: Production photo of Menelaus (Joseph Gay).

Throughout the war Menelaus, has not done much fighting. His older brother

Agamemnon has been leading the armies. Although Menelaus is trained in the art of war, he is no great warrior. His only battle was against Paris who, depending on the mythology, retreats or is swept up in a cloud by the goddess Venus.

It was key that the only thing glorious about Menelaus was his armor (Figure 62). $\mathrm{He}$ thinks he is magnificent but in reality, he is physically underwhelming. In the script Hecuba pulls off his helmet and reveals the man he really is, the chorus and Hecuba then go on to make fun of him for being bald. A greasy, unkempt comb over gave his character an unsettling appearance 
(Figure 63). He wears a bright red chiton bordered with a Greek key design (Figure 64).

His armor is stunning in appearance and unlike most armor of that time it is made of gold. Bronze was the preferred metal because of its durability; unlike gold which was considered an ornamental luxury. Every detail of his armor is for show because he is constantly trying to convince people and himself that he is a great warrior.

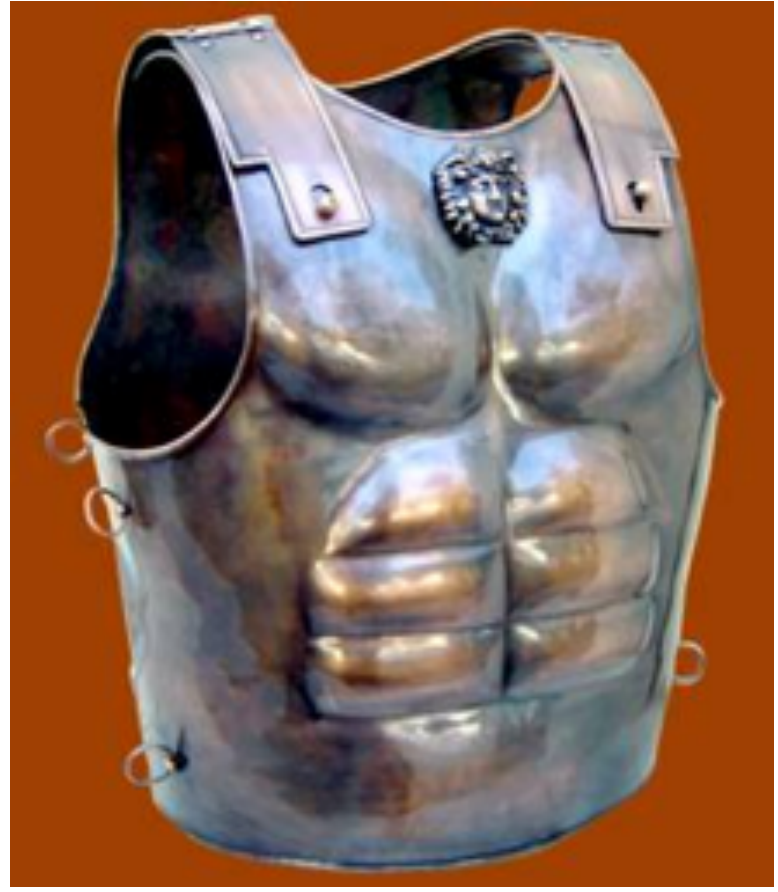

Figure 62: Research image of a cuirass.

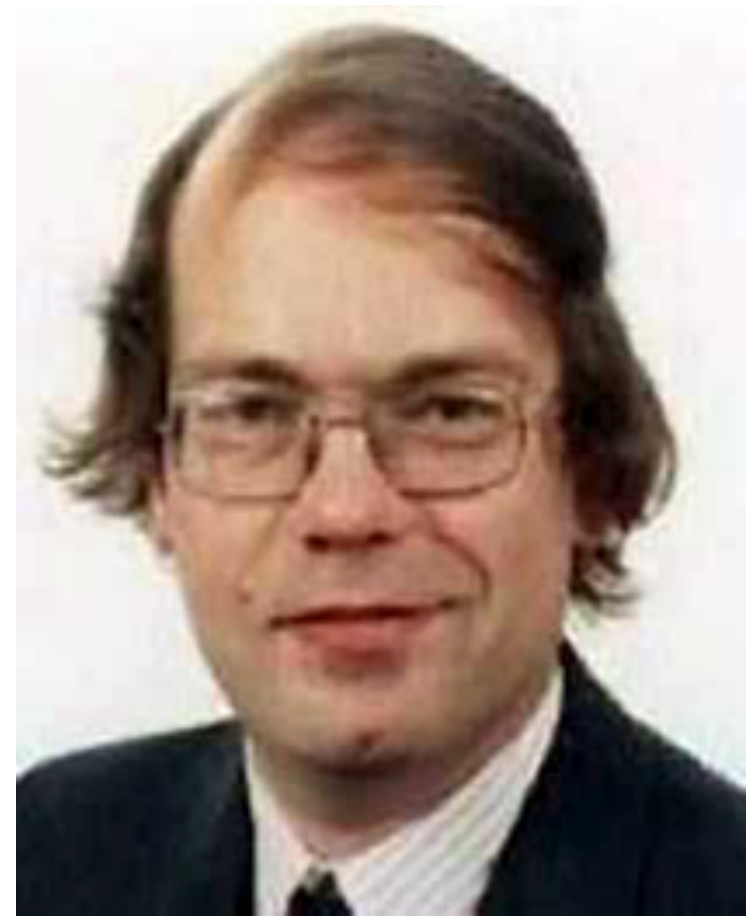

Figure 63: Research image of combover.

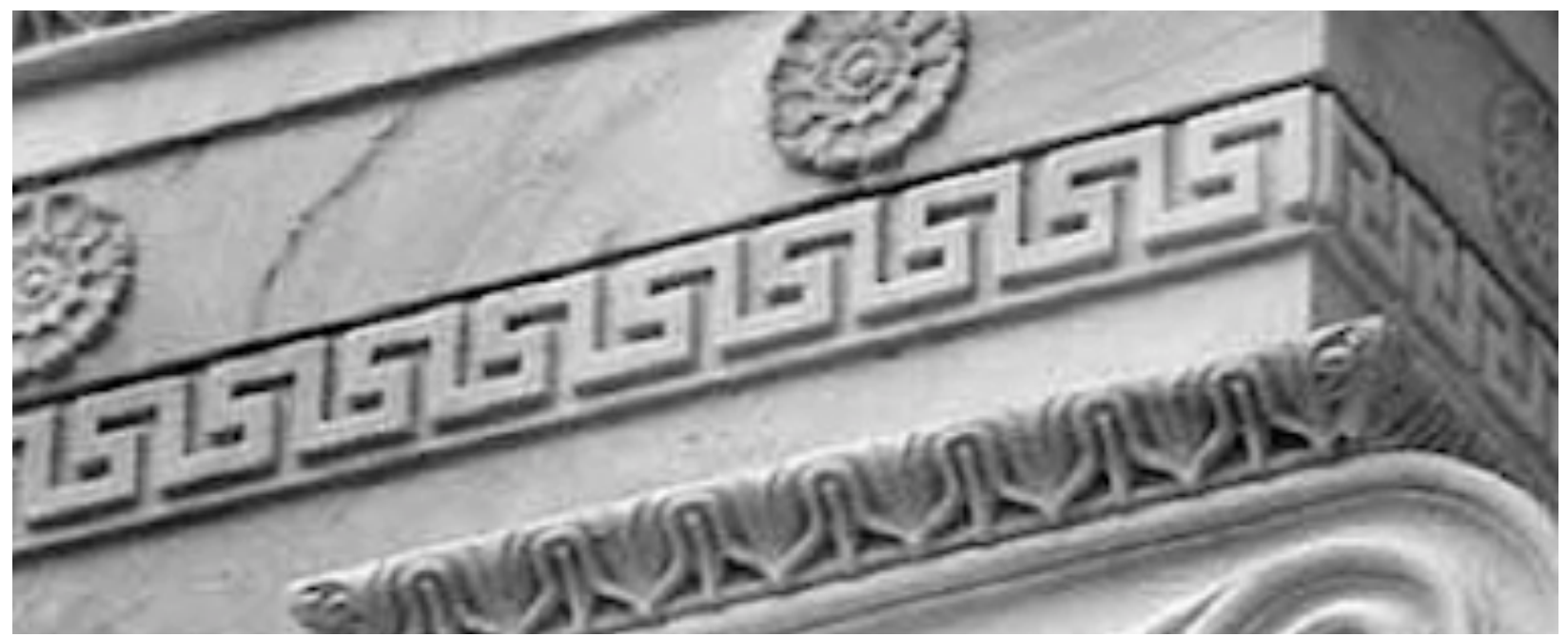

Figure 64: Research image of Greek key motif. 


\section{PRODUCTION PROCESS}

\section{Organization}

Organization is a vital portion of the design process. I have learned over the years that organization and paperwork can make or break a show.

After final designs were approved I compiled a detailed piece list/budget (See Appendix V). This contained an image of each rendering, the actor's name, each item they would be wearing, fabric estimates, pricing, and links to garments I hoped to purchase. The budget also included estimated pricing for craft supplies and wigs. Having this chart was helpful for ensuring I knew exactly what we would be building and purchasing. Adding the rendering to the chart was helpful to the shop during meetings so that everyone could see the items that were listed. I made sure to keep my initial spending for fabrics and clothing items well under budget because I knew I would also be spending a significant amount on craft supplies and fabric dyes. Additionally, I set aside $\$ 400.00$ of my budget as a dry-cleaning and emergency fund.

I made sure to keep a comprehensive list of my spending throughout the production (See Appendix IV). Occasionally in the hustle and bustle of the costume shop, it is easy for receipts and paperwork to become out of order or misplaced. As each item was purchased, I would add it to the spending list in red. Once the paperwork was turned into the business office I would then change the red text to black, which helped keep track of receipts that still needed to be submitted. As I turned my receipts into the business office, I would make three copies, one for Prof. McClung, one for shop manager Sharon Goeres and one for myself. I numbered the receipt and added it into the show binder. This organization system came in handy on several occasions 
as several pieces of paperwork went missing after being turned into the interim program director. When the business office emailed looking for paperwork, I was able to present them with copies until the originals were found.

Orders from Amazon.com also posed a challenge. Amazon.com charges a credit card as items ship, so although one order was placed it could show as several charges on the purchased card. Each time this happened, I was able to find the items in my paperwork and give a new breakdown to the business office. Had these issues occurred in past semesters, it could have been a disaster as I was not as organized. I am grateful to my previous experiences with the business office to realize how important it is to keep track of each receipt.

I have learned in my two previous years of graduate school how imperative being organized is to the workflow of the costume shop. Previously Prof. McClung suggested creating a calendar to ensure each project was allotted enough time for completion. Prior to the onset of the build process, I created a detailed calendar showing each project and a date on which the project should be completed (See Appendix III). After creating the initial calendar I then sent it to Prof. McClung and Prof. Delligatti for approval. They each gave me edits. I subsequently made changes handing out copies to the rest of the costume shop personnel.

I also created a second piece list to be posted in the costume shop with check boxes to ensure everyone was aware of where each project was in the build process. The chart included boxes for first fitting, completed alteration, final fitting, dying, and completion. This did, however, become a bit confusing due to the number of craft projects for this production. In retrospect, I should have made a second chart specifically for all craft and wig items. I do think it would be helpful to use a similar format in the future for productions with a larger build. 
Because of the large amount of dyeing, there were a lot of white fabrics throughout the shop. This initially caused some confusion as to what fabrics were used for which costume. I created a chart for our cutter/draper with swatches of each fabric. The chart included a photo of the rendering, all layers of each characters costumes and a piece of fabric for each. After completion of dyeing, I added the new colored swatch to the book.

Despite a slow start to the first week, I then discussed with Prof. McClung the idea of creating a daily report, which she felt would be a good plan (See Appendix VI). I learned the value of this after working with shop manager Janet O’Neil at The Chautauqua Theater Company the previous summer. Daily reports allow everyone to keep track of the build of their projects and helped me as a designer see when things were falling behind. In addition to listing all projects, I created sections for general notes, fitting requests, shopping list and goals for the next workday. In the last section, shop personnel could detail what they would hope to accomplish in the next workday further helping me prepare in the event we needed unforeseen supplies. 


\section{Build Process}

After designs were approved, I sat down with Prof. McClung and Prof. Delligatti to discuss the build process for the production. Due to the simplicity of the garments, we were able to build everything for the principal characters. Sewing and craft projects were then divided up amongst the staff. Prof. Delligatti oversaw costume construction. Graduate student Lauren Brennan supervised all crafts, served as wig master and personally worked on the chorus masks, Menelaus' armor and his wig. Graduate student Katy Ellenich worked under Brennan to construct the soldier's armor. Costume shop manager Sharon Goeres took on the build of Helen's dress since the material was too advanced to allow lab students help. Graduate student Laura Plikerd was assigned to assist me with the dyeing of fabrics. With her help I dyed the chorus costumes. I also constructed the two crowns for Poseidon.

I was excited to have Brennan as the Wig Master for this production. She had spent the previous summer working for American Players Theater constructing wigs, which was fortunate because this production called for a balding man. Brennan was able to custom build a fully hand tied wig for the character of Menelaus (Figures 65 \& 66). Prof. McClung also supervised the building of the other wigs, as it was her class that was

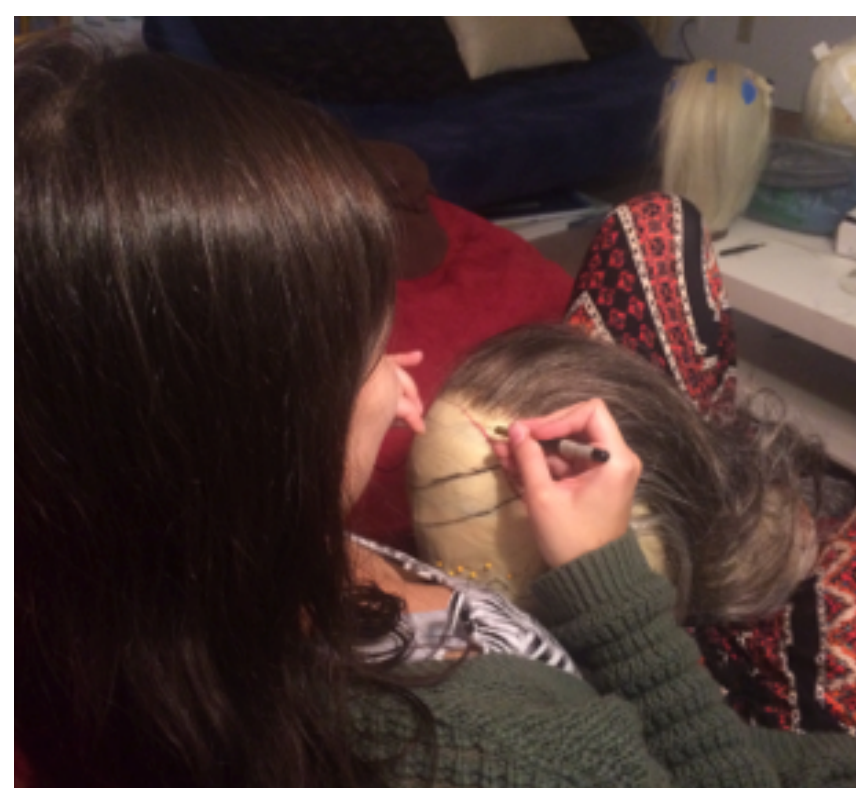

Figure 65: Brennan ventilating Menelaus' wig. 
completing the majority of the work. As head wraps were completed, Brennan and I worked closely to choose the best hair color for each of the actors and order wigs. I compiled a binder of research for hairstyles organized by character. This was kept by the wig workstation so that each student had access to the research.

Laura Plikerd created dye samples for each of the main characters based on the colors in the renderings. After some discussion, she was able to complete the dyeing of the fabrics for the main characters. Garments being dyed with an ombre technique needed to be constructed first (Figure 67 $\& 68$ ). For the nine chorus costumes, we were able to enlist the help of lab students (Figure 69). We broke the process up into three days, one day for each group of chorus members. The three techniques used were pole wrapping, scrunching and ice dyeing.

The process of creating the masks went quickly and smoothly. Lauren Brennan supervised students who created the broken pottery masks by

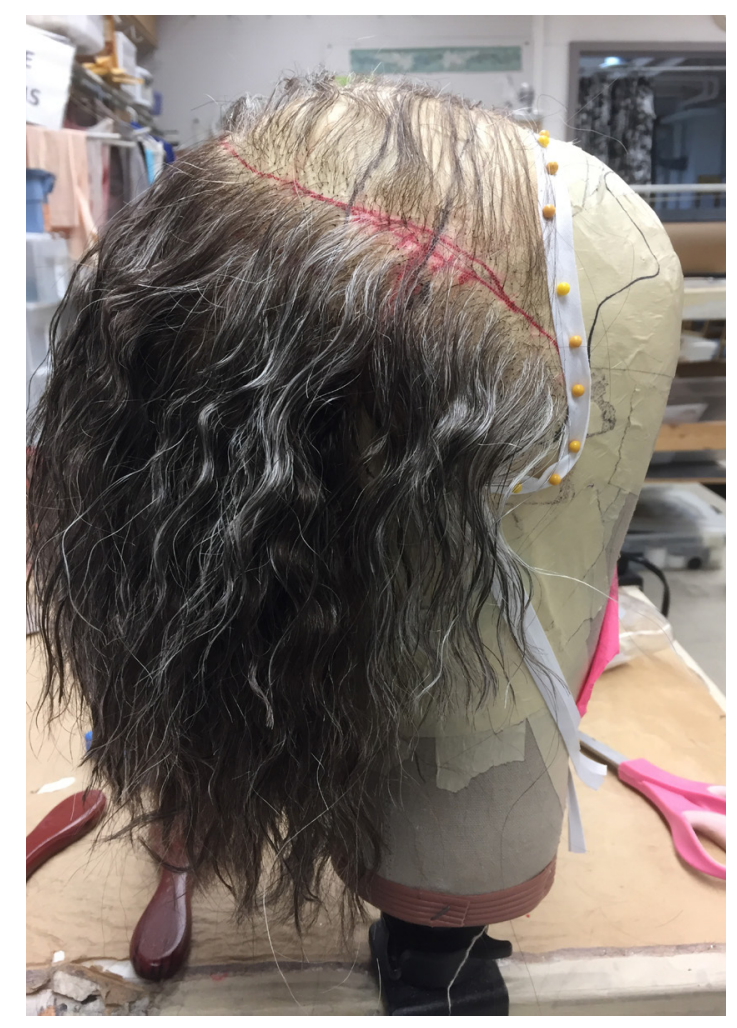

Figure 66: Menelaus' finished wig.

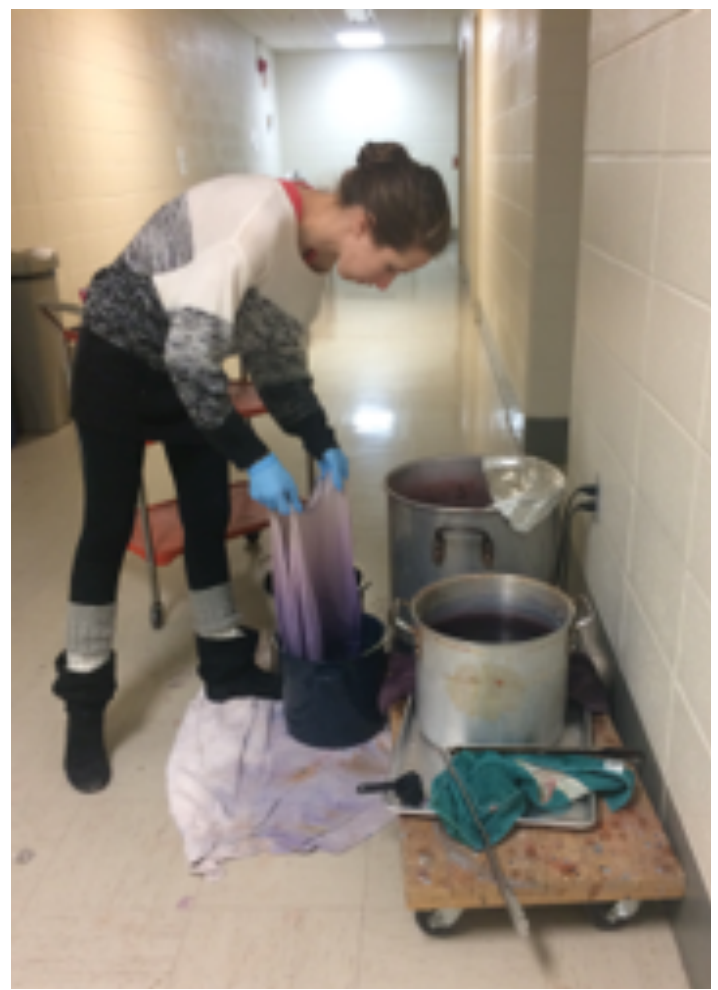

Figure 67: Ombre dying Andromaches' Doric peplos. 
having them build up layers of craft foam on a plastic mask (Figure 70) and covered them with papier-mâché. She then sculpted three masks to look like broken faces of statues (Figure 71). After the masks were primed, Brennan received paint samples from the scene shop and painted the masks to match the set (Figure 72). The difficultly came when trying to determine the best method for the masks to stay on the actors. I originally planned to have elastic straps around the back of the head, much like the rehearsal masks the chorus was already using. Through the rehearsal process, Dr. Malarcher noticed that the elastic band did not suit the concept of the production and asked if there was another method to keep the masks on. After several different methods and prototypes, Brennan was able to create nude Velcro headbands the actors could wear throughout the entire show, the Velcro inside the masks would then stick to this headband.

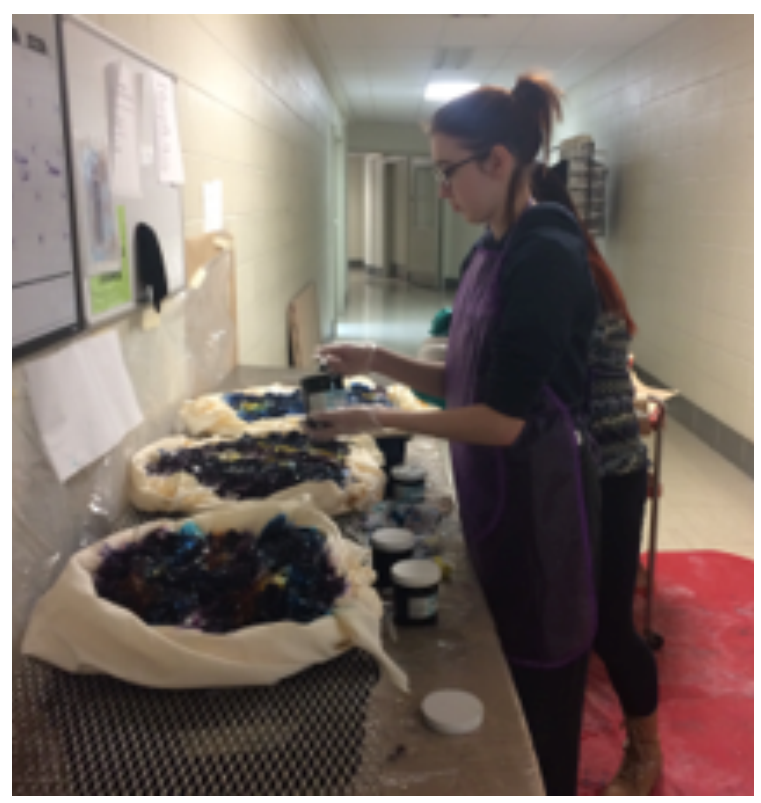

Figure 69: Students ice dyeing chorus costumes.

After seeing the uneven terrain on the

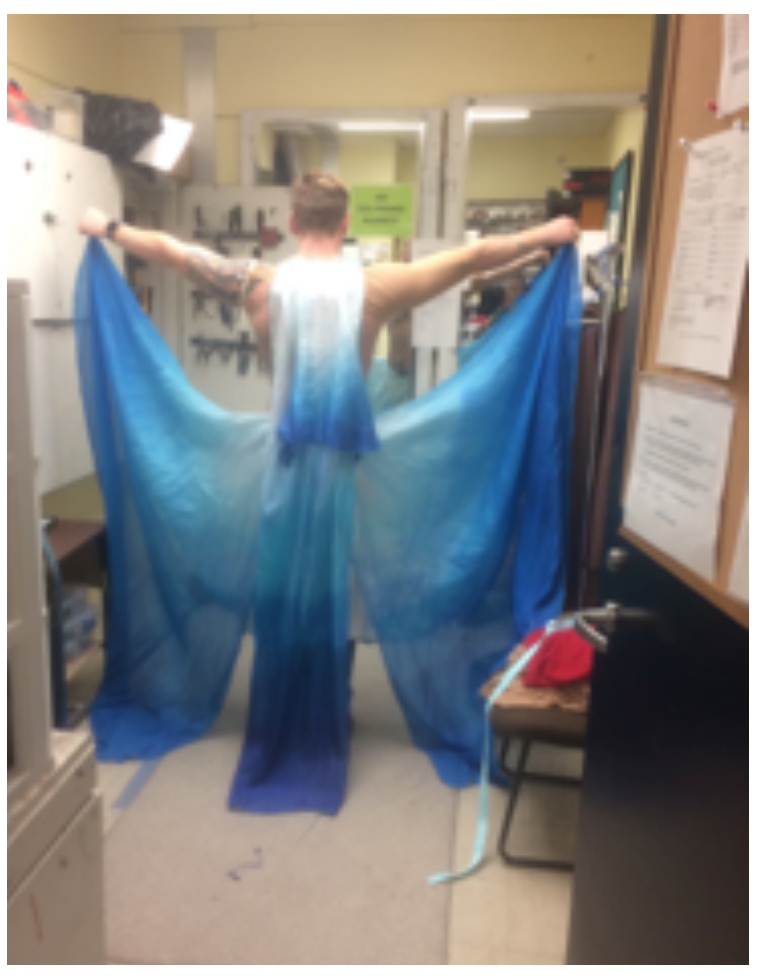

Figure 68: Fitting photo of Poseidon's skirt and cape. 
scenic model, it was imperative for the actors to rehearse in shoes similar to what they would be wearing. The chorus in particular would be doing a lot of movement work and it was crucial that they become used to the footwear. During the week prior to dress rehearsal I asked the stage manager to have the actors try their show shoes on stage. Thankfully, we discovered early on that several of the pairs of sandals were slick. We were able to correct this by swapping out the shoes before full costumes were added.

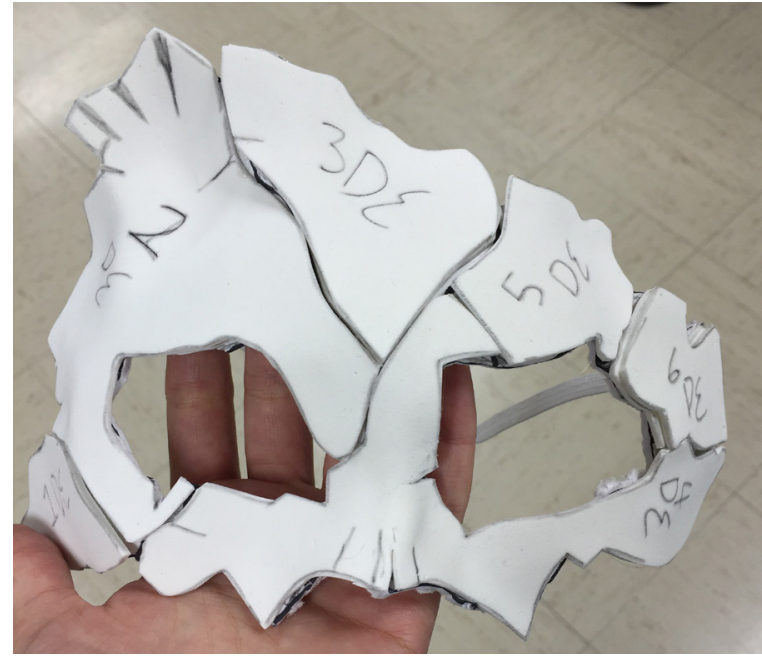

Figure 70: Process photo of foam shapes built up on mask.

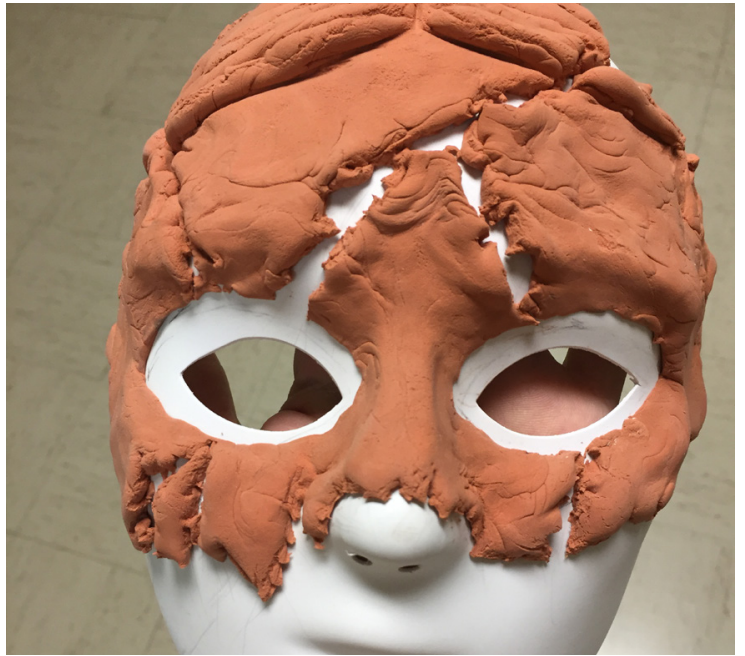

Figure 71: Process photo of clay sculpted on mask.

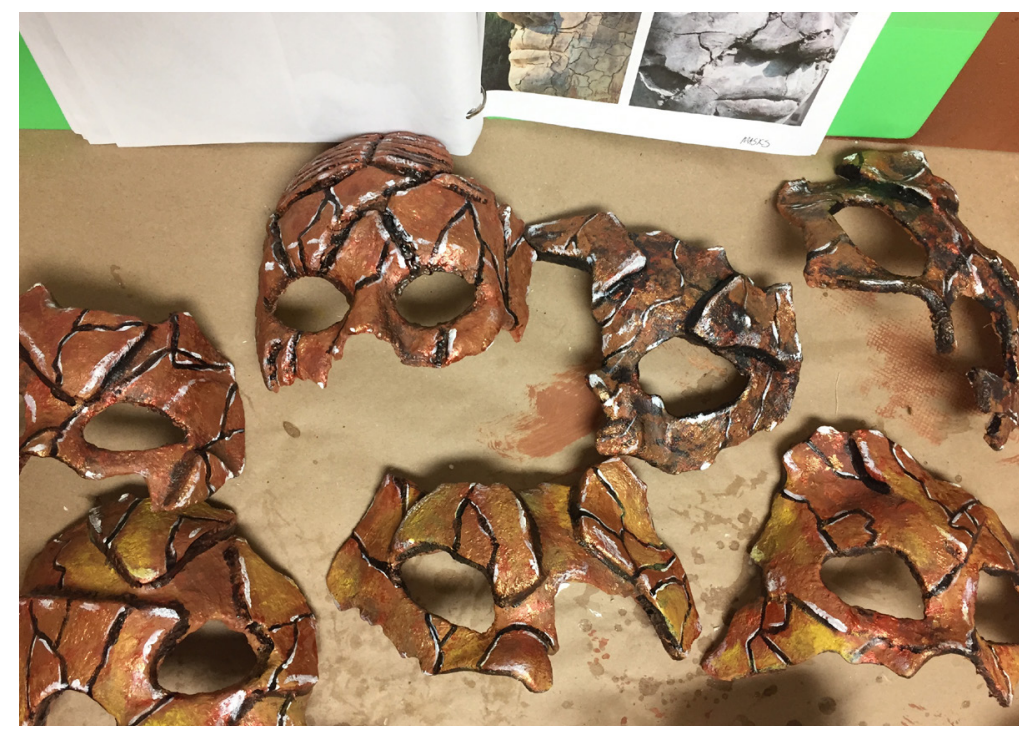

Figure 72: Process photo of painted chorus masks. 


\section{Communication}

Although I knew the importance of communication, I am still learning how to articulate my thoughts. Over my time at West Virginia University there have been many changes in faculty and functions of the costume shop. On several occasions during this process, I failed to properly communicate my ideas and also ran into instances where I misunderstood instructions. I am thankful to have these instances arise while still in an educational and nurturing environment.

When working with the same people often, you can grow familiar and forget to clarify directions. This happened when Prof. McClung asked me to have dye samples for the chorus ready on Monday. I mistakenly thought she meant by lab time 1pm on Monday, since we often are preparing things for that time frame. In reality, Prof. McClung had wanted the samples for our Monday morning shop meeting to discuss the techniques with the rest of the team so that they could help in the larger dying projects. I was fortunate that my misunderstanding did not set us behind on projects. In the future I will make sure to clarify any deadlines.

While discussing working drawings, Prof. Delligatti asked me to do a working drawing of Poseidon standing still to see what the costume would look like in a resting position. She created a mock up of what she interpreted from my working drawing. Initially, the mock up was not how I thought we would be building the costume. I was worried about the function but did not want to cause any form of confrontation with Prof. Delligatti. My fear of confrontation was due to a past cutter/draper who was pushy and would get mad and aggressive if you asked to change anything. I was fully prepared to give up the look of a costume for the fear of conflict. A fellow graduate student encouraged me to speak to Prof. Delligatti about my concerns and express the 
experiences I encountered in the past. Through this conversation, I was able to discuss with her the function of Poseidon's costume and see that the mock up she created was far closer to what I was envisioning than I had previously thought. We talked through a few changes and ended up with a truly beautiful product. I am so grateful for this encouragement because after speaking with Prof. Delligatti she understood completely. Throughout the rest of the process she would make sure to express to me that I could continue making any changes needed during the mock up phase. 


\section{EXECUTION OF PREFORMANCS}

\section{Dress Rehearsals}

Organizational paperwork was arranged for the wardrobe crew before the start of technical rehearsals. Costume Shop Manager, Sharon Goeres and I worked together to assign cast members to dressers in order to evenly distribute the workload. Since this production did not have any costume changes, the crew was responsible for assuring that the costumes and wigs were worn properly, laundered, and repaired.

Wig training for cast and crew was held on the Saturday prior to first dress rehearsal. At this training Prof. McClung, Wig Master Lauren Brennan and myself instructed the crew on how to properly care for lace front wigs. The actors wearing wigs were asked to arrive with their hair in pin curls so that the crew could practice putting wigs on their assigned actor. Also in attendance were Martha West and Michaela Edens, who were in charge of restyling wigs throughout the run of the production. Joseph Gay, who played Menelaus and the two students applying his bald cap, attended a separate training due to the complexity of the application process.

Each crew member was given piece lists detailing each item their actors wore throughout the show. Before the actors arrived to the first dress rehearsal, I met with the wardrobe crew to go through each item on the costume rack. As I went through the rack of costumes I announced the actors' names and asked which dresser was assigned to that actor. I would then show the dresser each costume piece and explain how and when that piece was to be worn. This was a very 
important step in the process due to the number of layers and armor pieces worn by several of the actors. The dressers were also informed of any special care instructions for the maintenance of each item.

After watching the first dress rehearsal, I had a long list of notes. The wigs for Hecuba and Andromache needed to be restyled. Menelaus' helmet was too tight for his head over his wig. Belts needed to be added to the costumes of Menelaus, Talthibyus, and Helen. The chorus costumes had too much white and needed to be re-dyed. Finally, the nude coloring of the Velcro headbands of several chorus girls was visible when placed over their hair.

The Wig Master spoke with Katy Ellenich, explaining how to restyle Hecuba's wig and made the small corrections to Andromache's. Prof. McClung expanded the helmet for Menelaus enough to fit over the actor's wig.

I pulled trims to be used as belts for the several costumes. I knew dying would be a big undertaking, so I chose to stay after the dress rehearsal to fix the chorus costumes. I was able to handle the process on my own because we had so recently used the technique. By using the same colors in heavier concentrations, the costumes glowed much less under the stage lights. I spoke with the wardrobe supervisor Adam Demopoulos about custom-coloring the sides of the chorus headbands with markers to better match the actor's hair color. Brennan also assisted in this process by showing several of the chorus members how to style their hair in such a way that would more easily cover the headband.

My list of notes following the second dress rehearsal was significantly shorter. The chorus costumes were a much better tone after having been over dyed. There were a few fitting notes, mostly centered on the comfort of the actors. Hecuba's wig needed to be restyled a second 
time because the wrong sized curlers had been used to achieve the given style. While several of the chorus headbands were less visible than before, there were still a few that were very noticeable.

By final dress rehearsal, all the major notes had been corrected and the show looked just as I imagined it would.

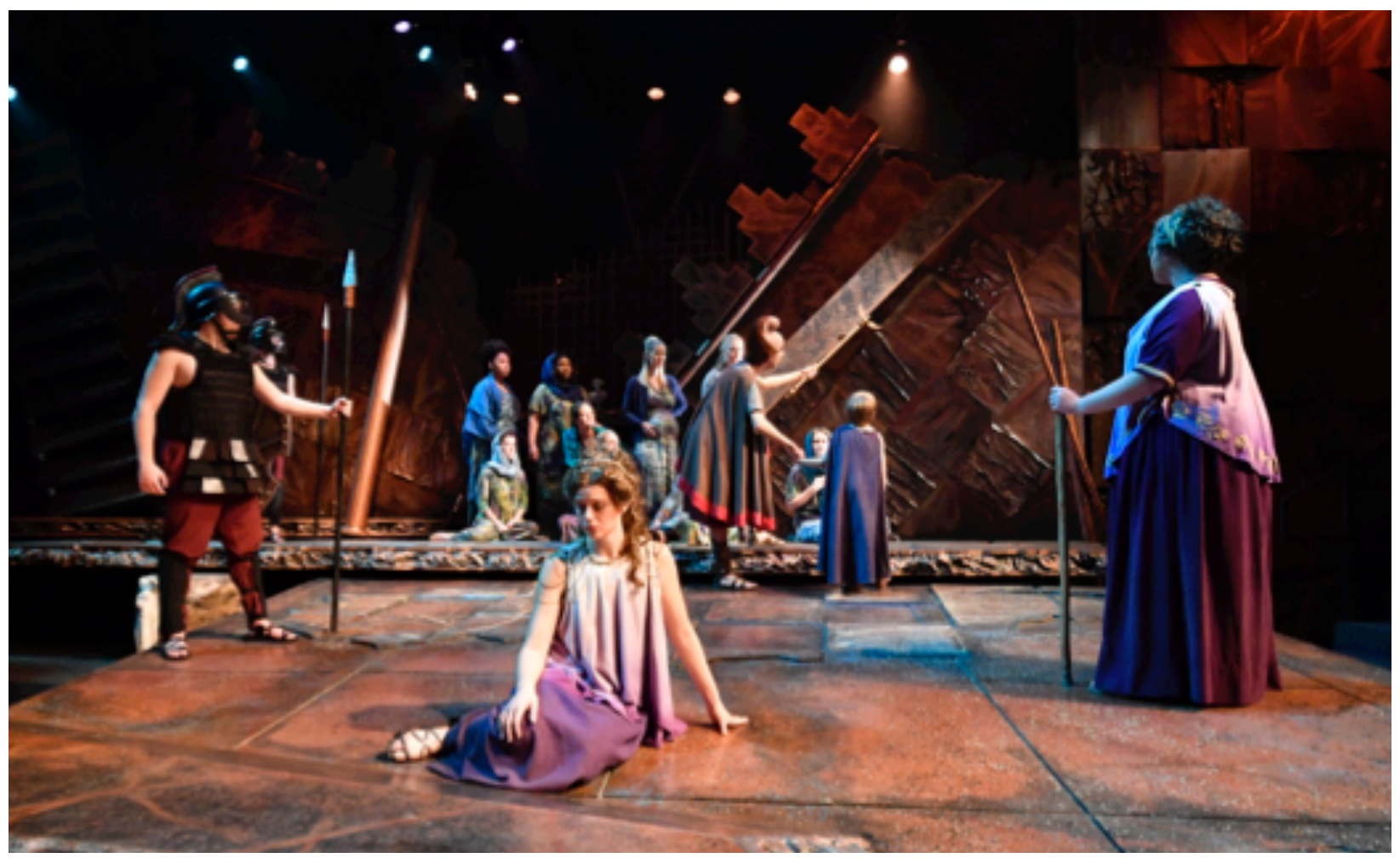

Figure 73: Production photo of Talthybius taking the child away from Andromache. 


\section{Run of Production}

Throughout the run of the production, only a few issues arose. For example the version of Poseidon's crown that was thrown at the end of the production had pieces break off, and those pieces were not repaired after the first couple performances. I spoke with the dresser responsible for Poseidon's costume and asked her to make sure to check the second crown for any necessary repairs after each performance. She kindly acquiesced.

The placement of flowers in Cassandra's wig was a minor, but constant issue.

Ms. Brennan had done the original arrangement and took photos for the wig crew to replicate after each performance. Unfortunately, the maintenance was not executed as directed, which caused the character to look less refined than I intended.

During photo call, which occurred about halfway through the production run, I fixed the bottom of the chiton of the actor playing Menelaus, which was tucked up into his belt higher on one side. After I made this correction, the Stage Manager, Rebecca Smith, approached me and asked if that was the proper way he should be wearing his costume. For a few nights he had been wearing his costume unevenly and his dresser had not corrected the issue. I then made sure to speak to both actor and dresser so that the skirt should be worn with the hem hanging evenly. Other than these minor issues, the run of the show went without incident. I was extremely grateful to have Adam Demopoulos as the Wardrobe Supervisor. He was conscientious, a great problem solver and made sure to ask questions when unsure of proper procedures. 


\section{Production Outcome}

Most of the costume design worked well for the production. However, the use of the masks ultimately created some disconnect with the scenery, which caused confusion for some audience members. After speaking with friends and family to gauge their reactions to the production I learned that there was much misunderstanding over the purpose of the masks. One friend thought that the chorus women were using the masks to hide from the men, while other friends mentioned that they found them distracting, as they could not decipher a consistent purpose for their use.

Originally, the masks were designed to look like the set and artifacts as a way for the chorus to connect to the named women. Dr. Malarcher wanted the chorus to interact with the

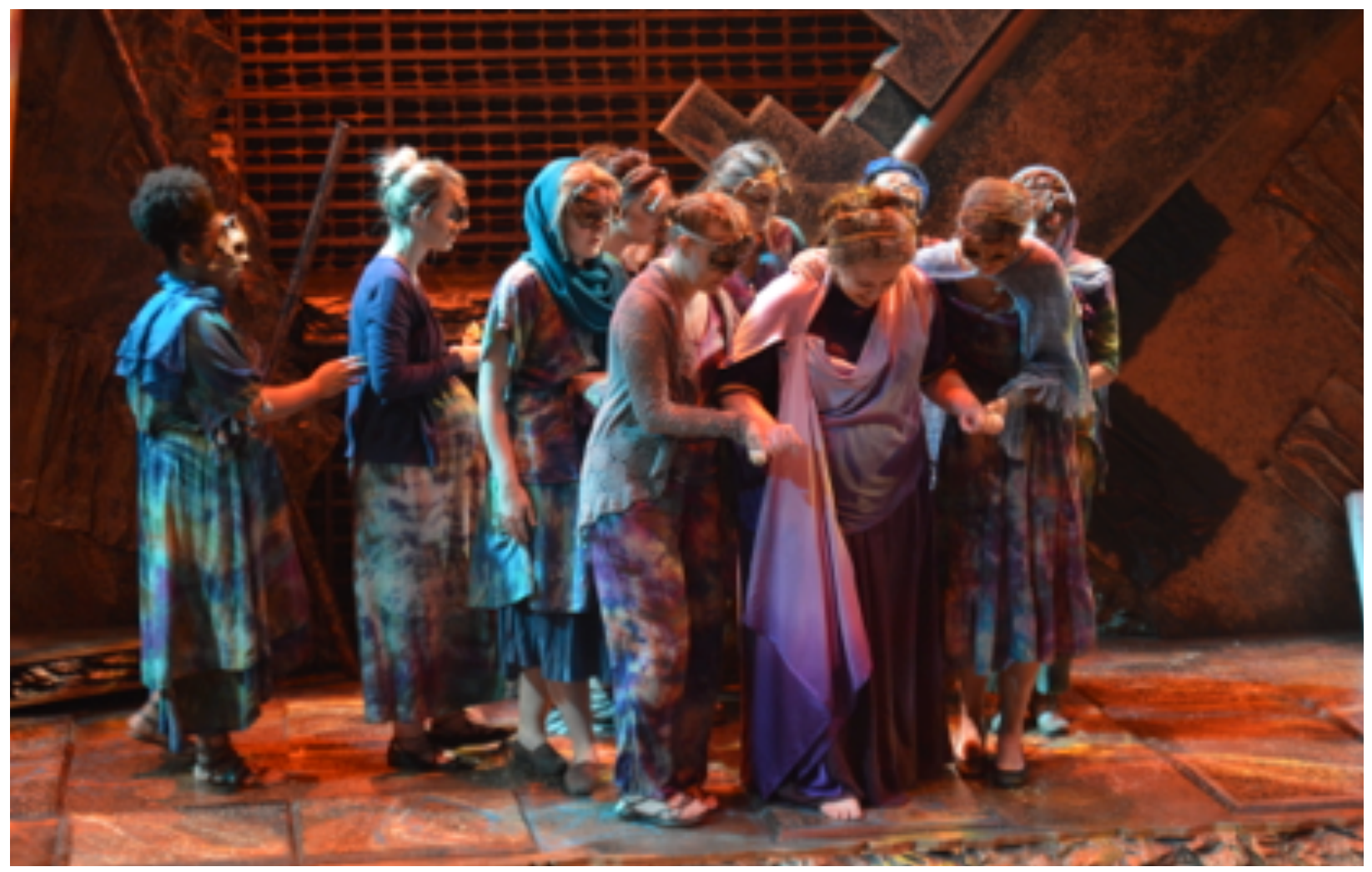

Figure 74: Production photo of the masked chorus leading Hecuba. 
Trojan women through broken artifacts and the masks. The artifacts were designed to look like the Trojan women to convey a direct connection between them. Due to time constraints, the artifacts remained unpainted well into technical rehearsals. Dr. Malarcher asked the scenic designer to leave them white, as he liked the way the artifacts glowed on stage because of the contrast with the copper set. Initially I did not feel this decision would have a major effect on the production, but after watching several runs I believe that this choice took away from the overall aesthetic. Leaving the artifacts white caused a disconnect in a place where we were trying convey a correlation. The masks and artifacts were meant to work together to connect the chorus and Trojans, but this drastic color difference ended up causing confusion. I also feel that if the artifacts had been larger it would have helped make the relationship more pronounced.

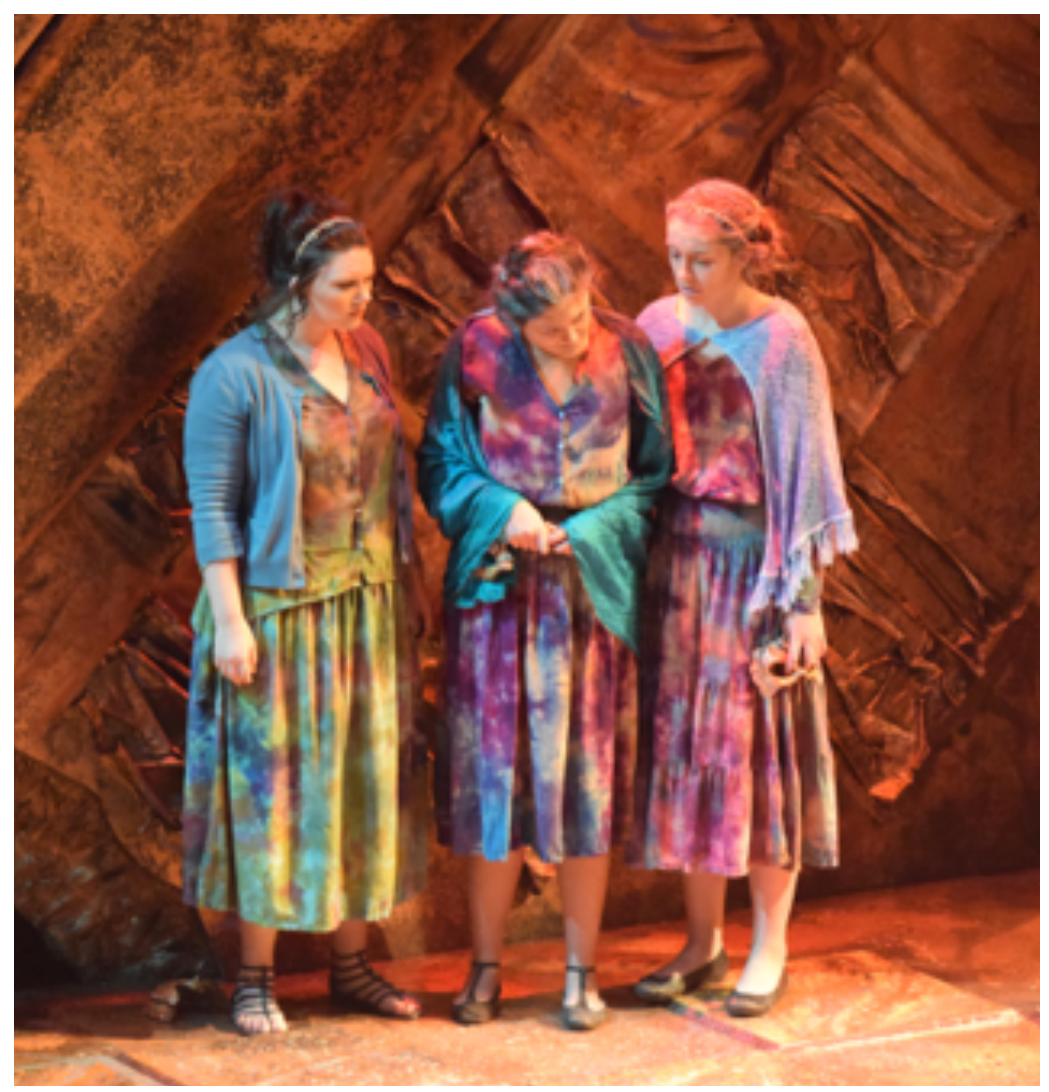

Figure 75: Production photo of unmasked chorus members. 


\section{Learning Outcomes}

As costume designer for The Trojan Women, I learned the importance of troubleshooting and proper time management. This was the largest design I have worked on at West Virginia University. I have learned from my previous semesters just how important it is to stay organized. I am thankful for my experiences working in professional shops outside of West Virginia University to see how a variety of people keep things on track. In addition, the examples of Cecelia Hill and Lauren Brennan, who both worked on large shows the previous two semesters, gave me additional information on how to keep on top of everything.

I am still learning how to deal with issues when they arise. Voicing my opinion when things are not what I had hoped they would be is a skill on which I will continue to work. In the past, having a cutter/draper who was overbearing and abrasive caused me to be very timid. In the past, I tended to avoid confrontation and suppress my thoughts rather than bringing up concerns. Through this process I was encouraged to speak up with positive and productive results, which has reinforced my ability to be assertive for future projects.

During this production, I had the experience of designing with a new team in the costume shop. My previous three designs were all with the same team of graduate students and faculty. The other two graduate students and myself had developed an unspoken understanding about how things should be done, which created an easy flow in the shop environment. This semester Cecelia Hill had graduated, and we gained two new graduate students and a new cutter/draper, Prof. Delligatti. This new dynamic forced me to rethink my methods of communication and 
reminded me how essential it is to be adaptable. As it is not uncommon to work with new and varying groups of people in this industry, I was very grateful for this experience. 


\section{APPENDIX I: RESEARCH PLATES}

Note: See Appendix II for individual citations for each research plate.

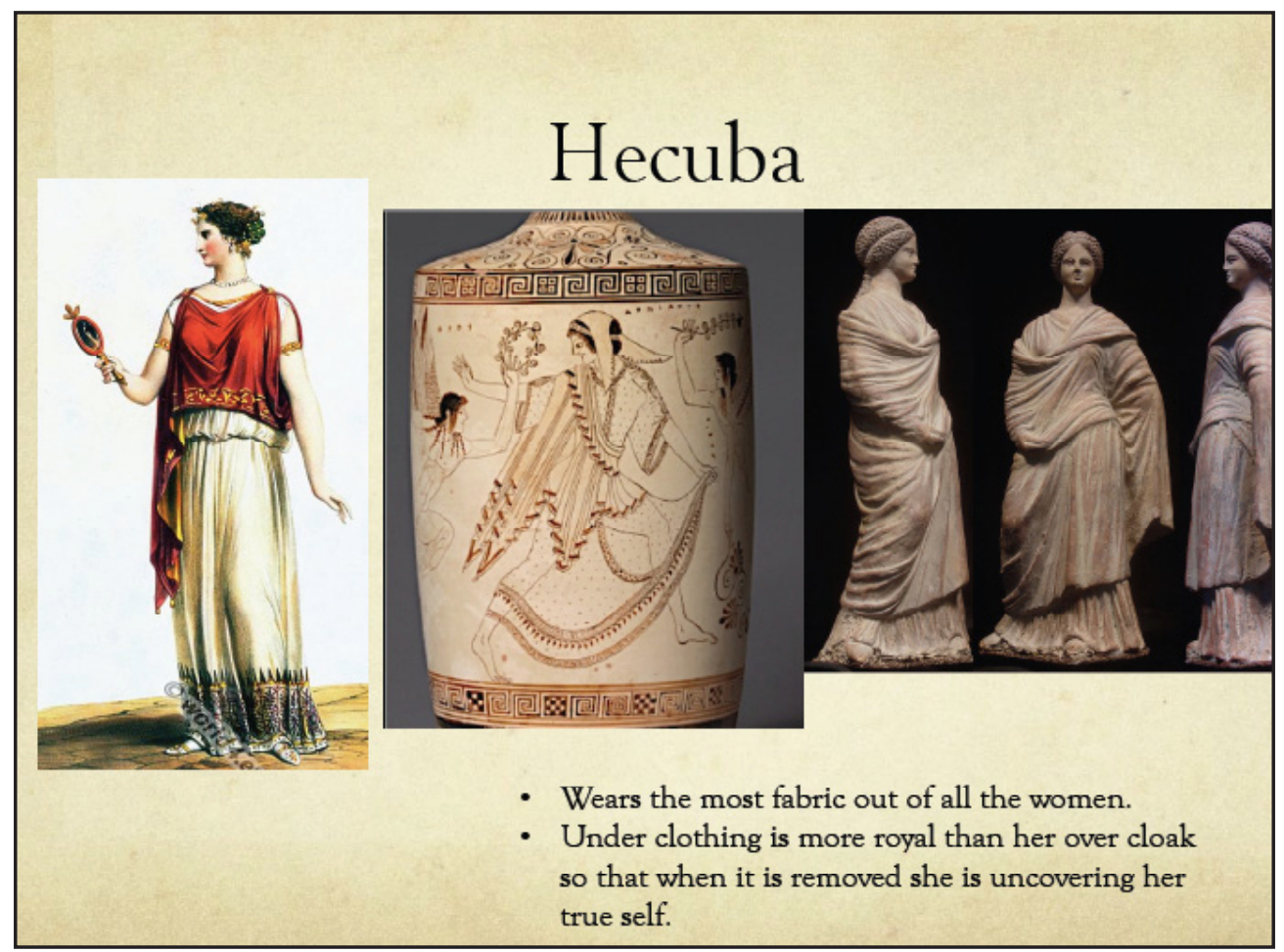

Plate 1: Research images for Hecuba.

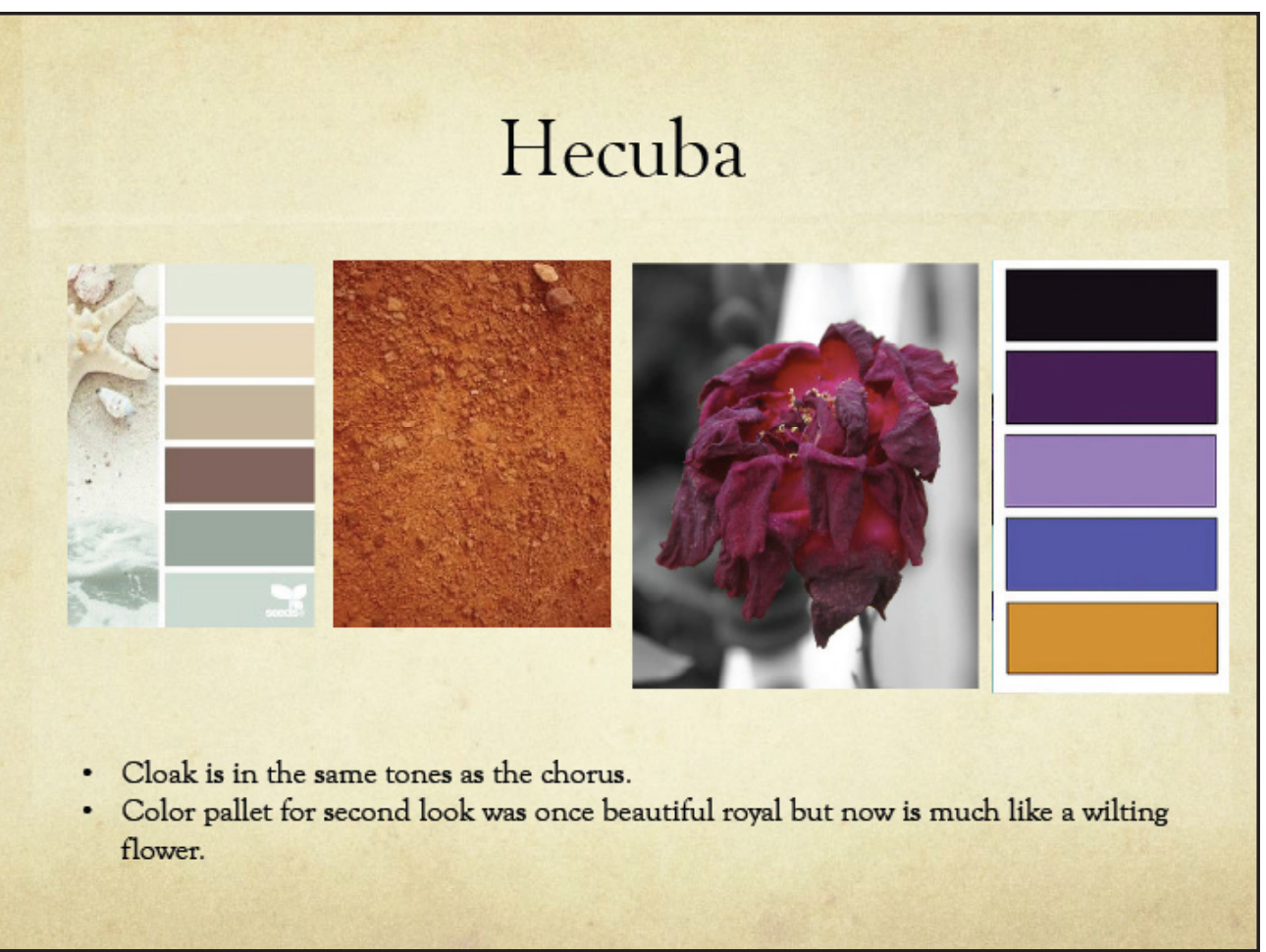

Plate 1A: Color and Texture research for Hecuba. 


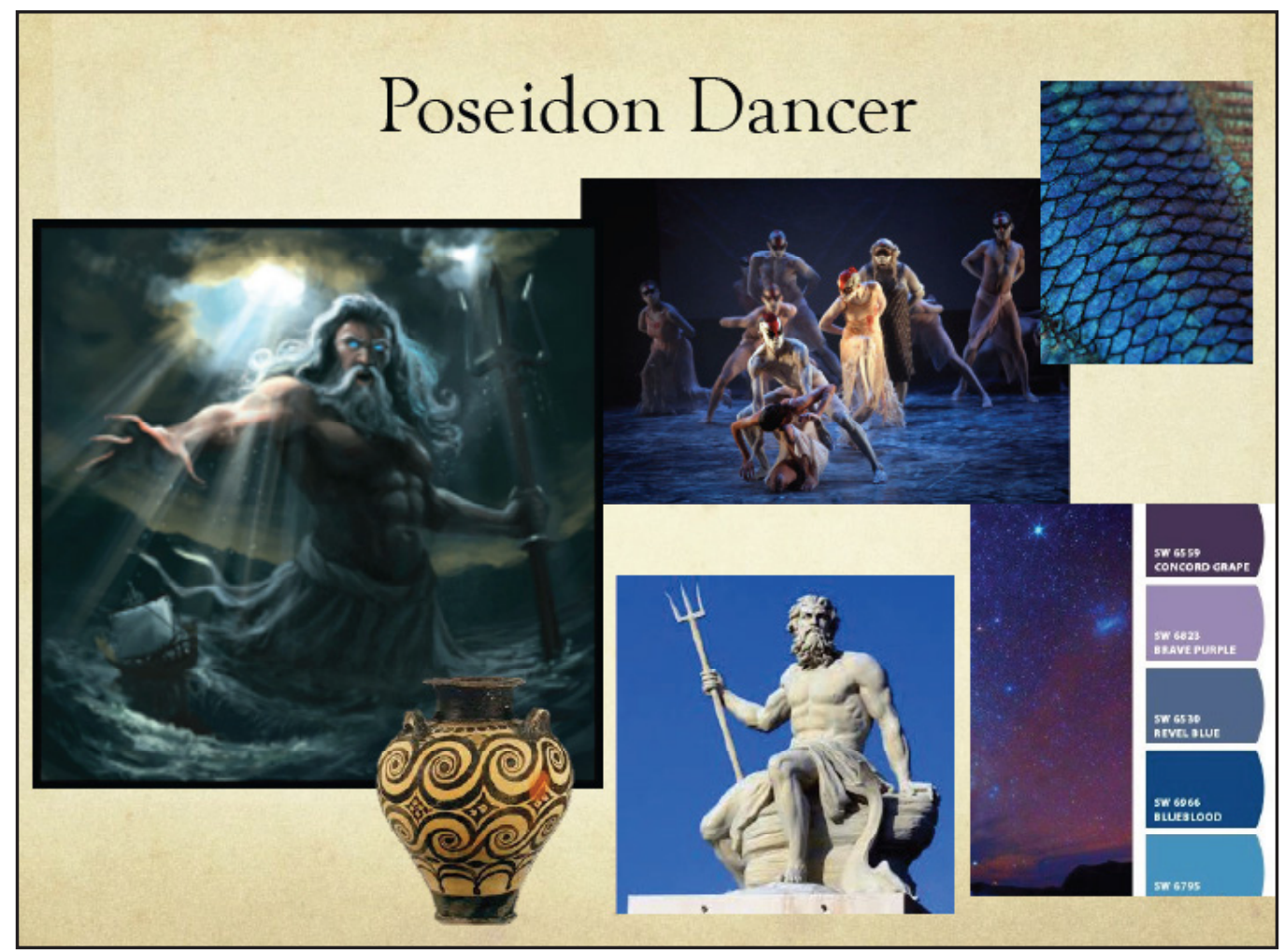

Plate 2: Research images for Poseidon Dancer.

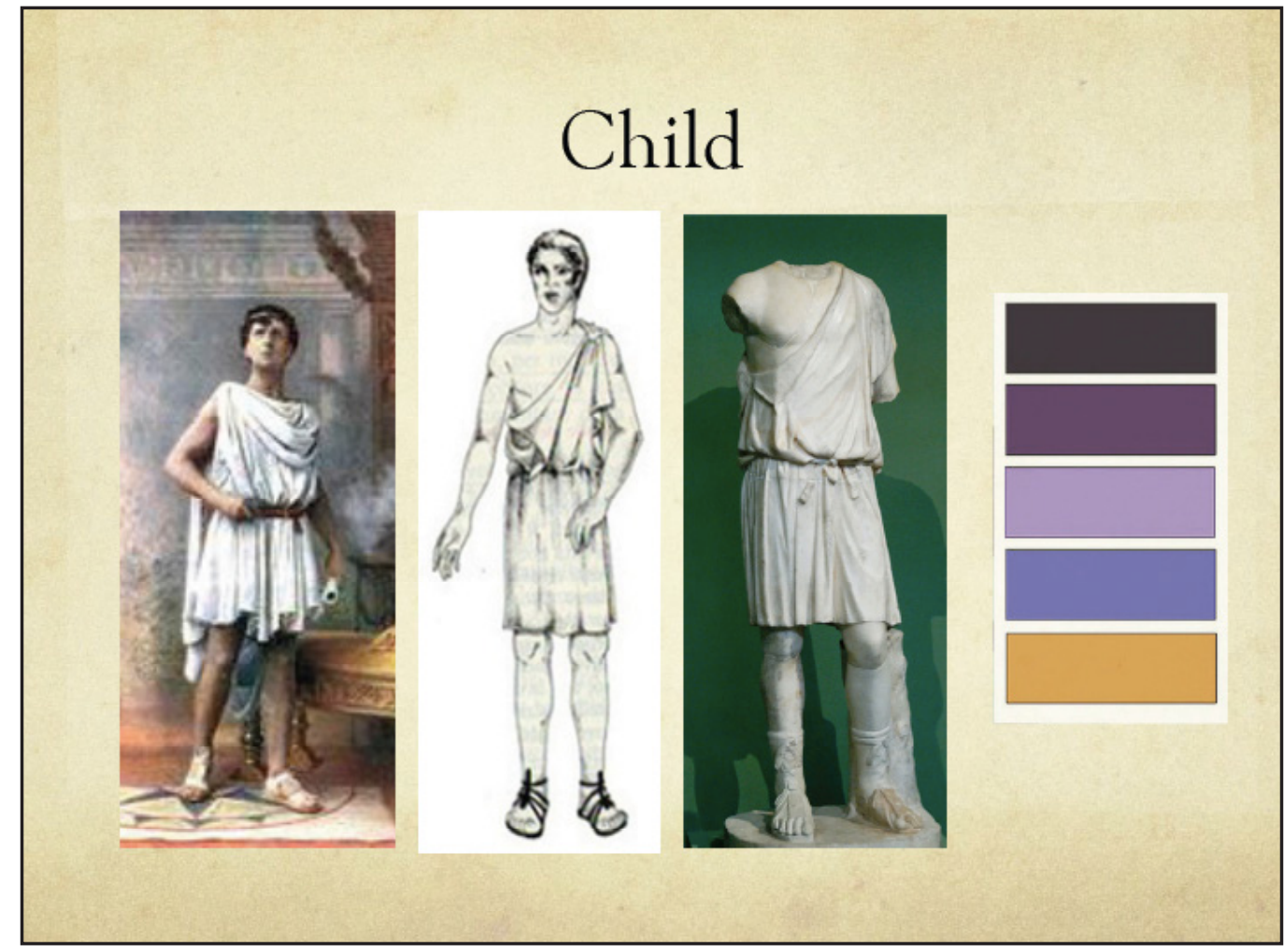

Plate 3: Research images for Child. 


\section{Cassandra}

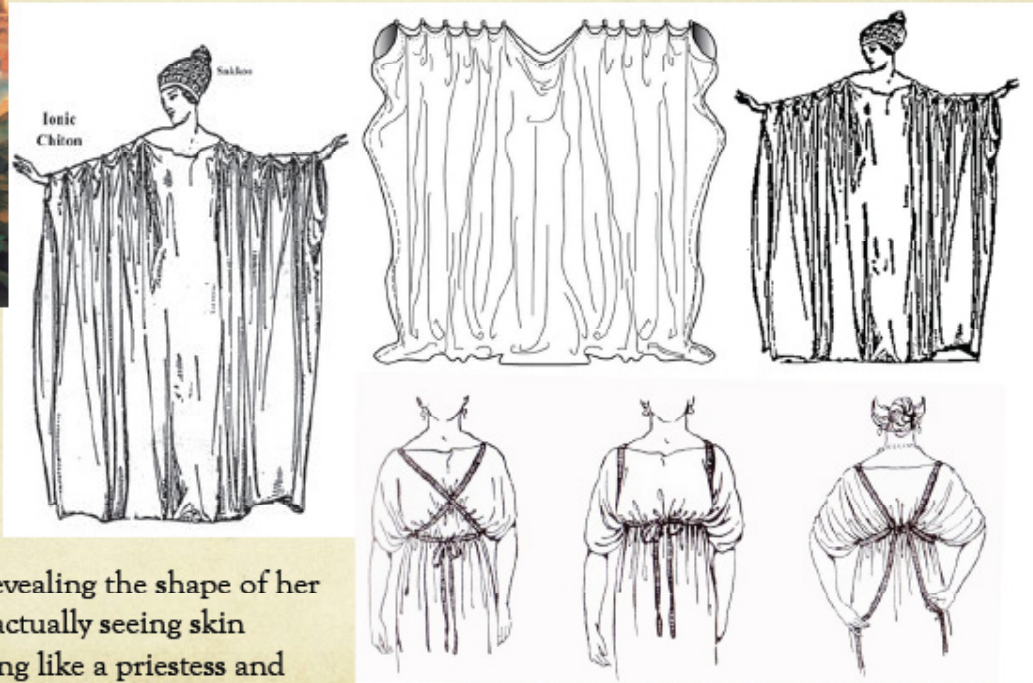

- Light Fabrics revealing the shape of her body with out actually seeing skin

- Starts off looking like a priestess and transforms into a virgin bride

Plate 4: Research images for Cassandra.

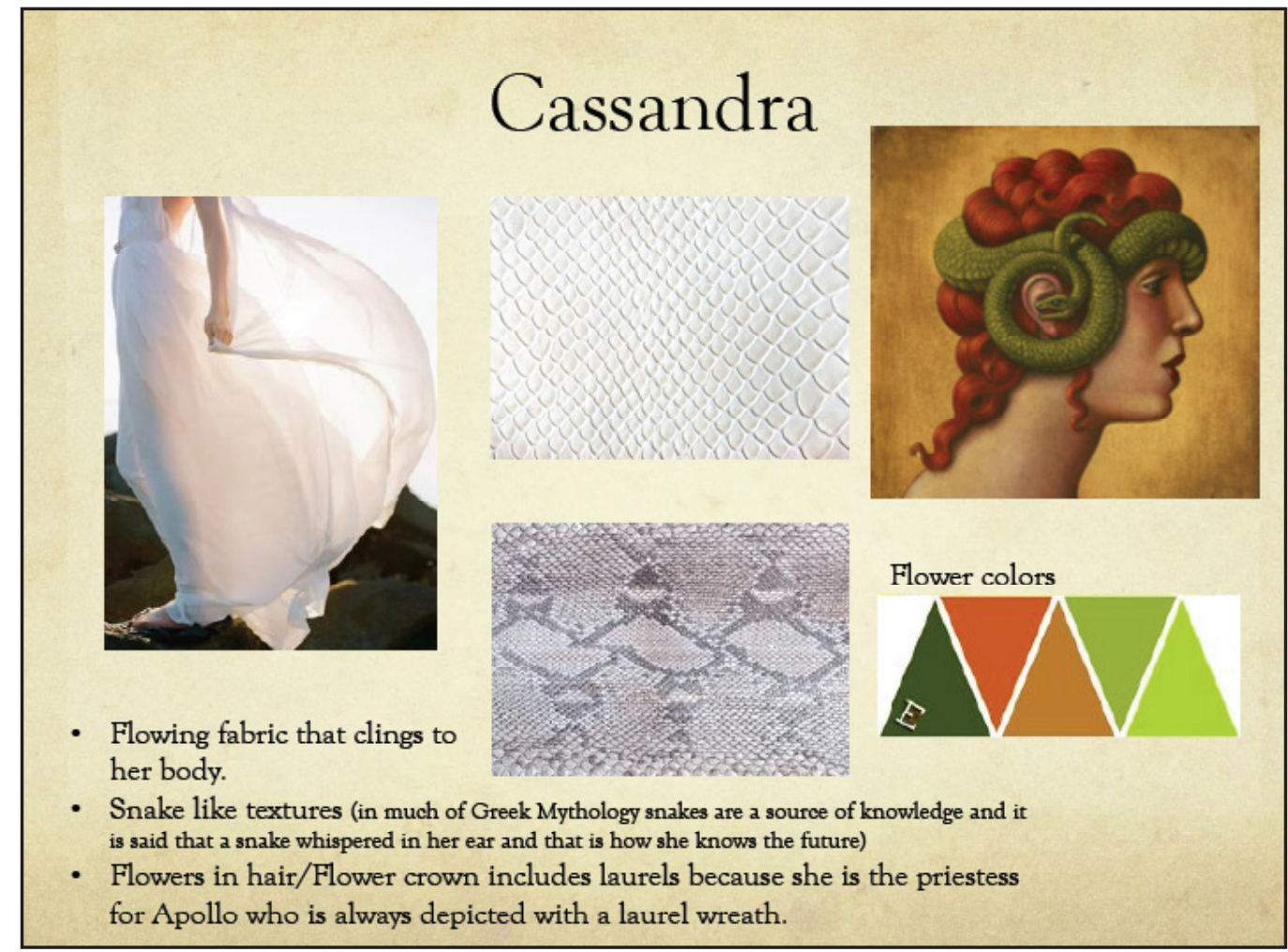

Plate 4A: Color and Texture research for Cassandra. 


\section{Andromache}
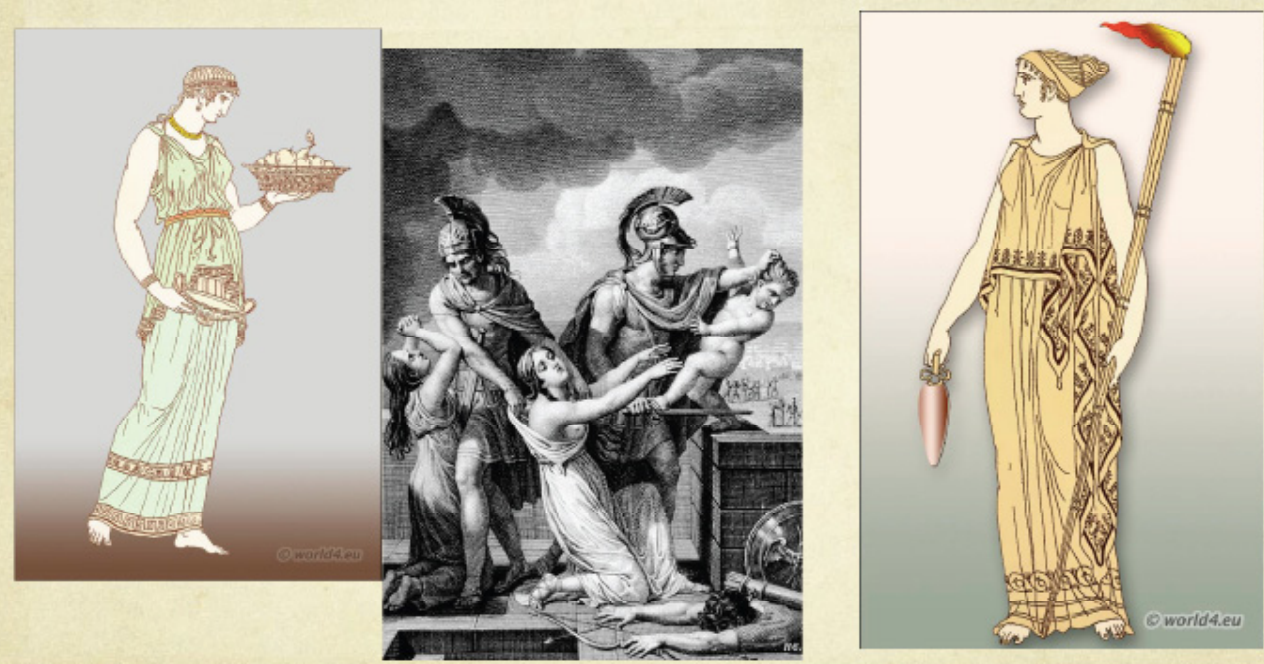

- Similar feel as Hecuba but simpler with less fabric

Plate 5: Research images for Andromache.

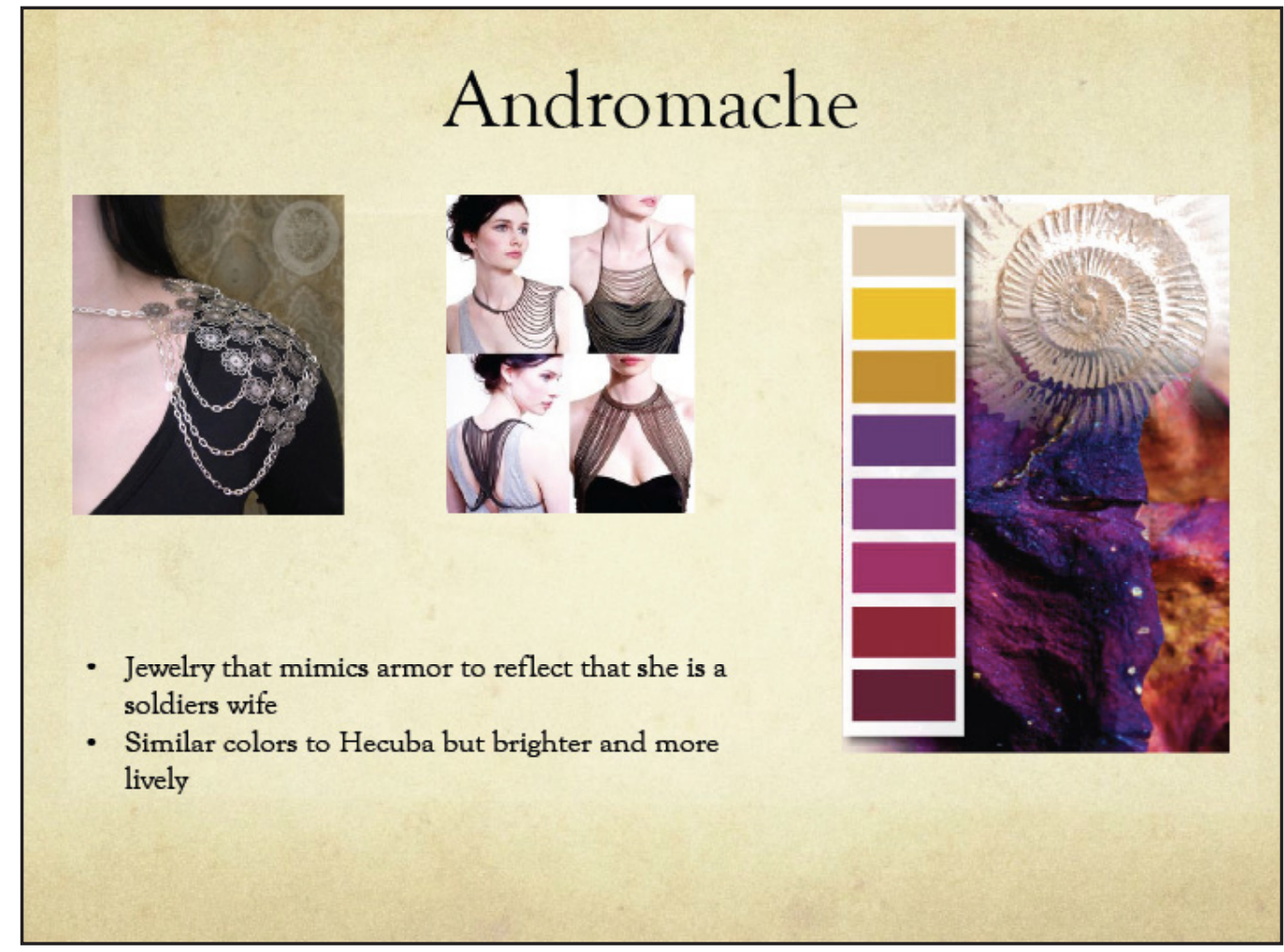

Plate 5A: Color and jewelry research for Andromache. 


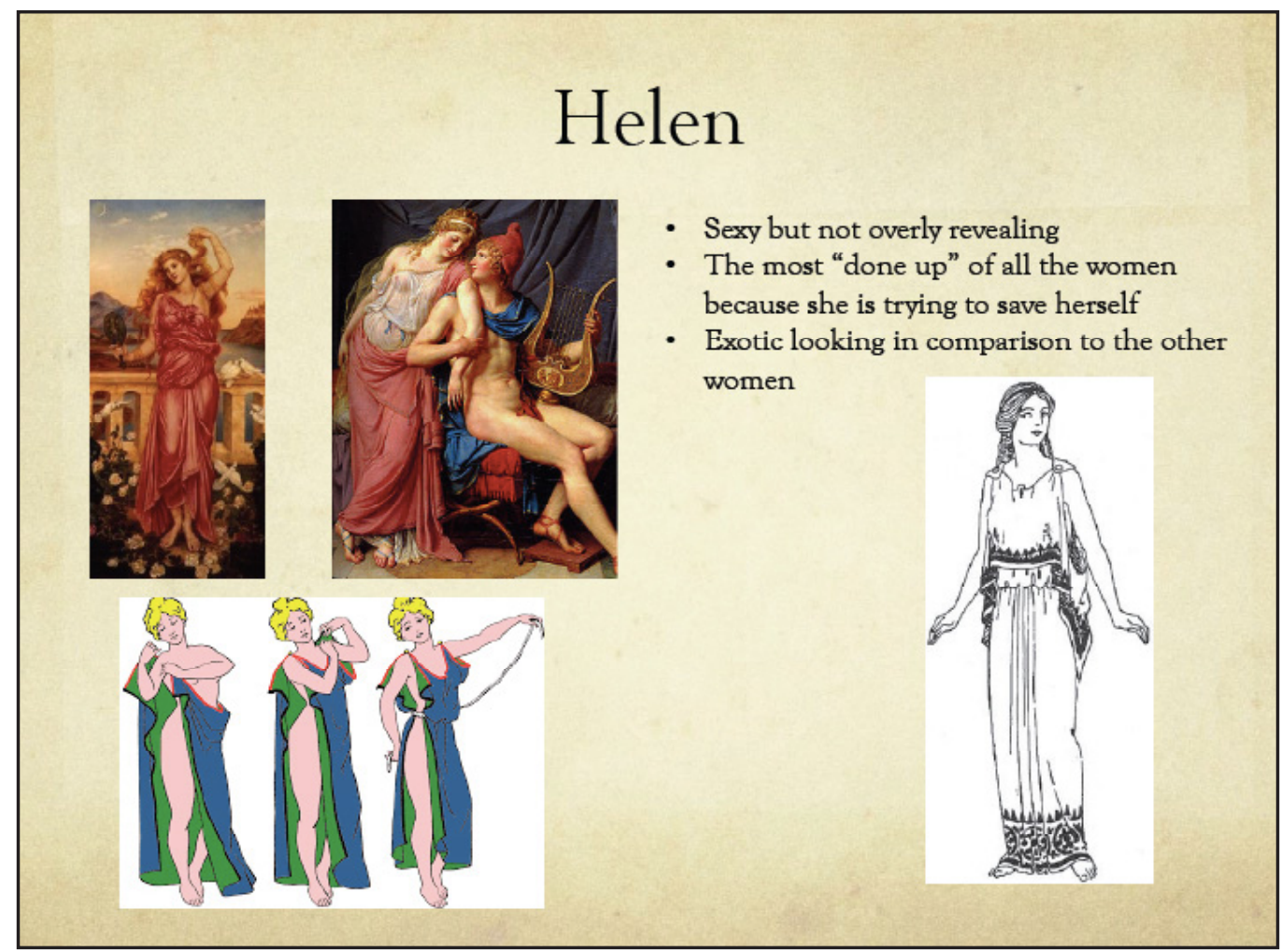

Plate 6: Research images for Helen.

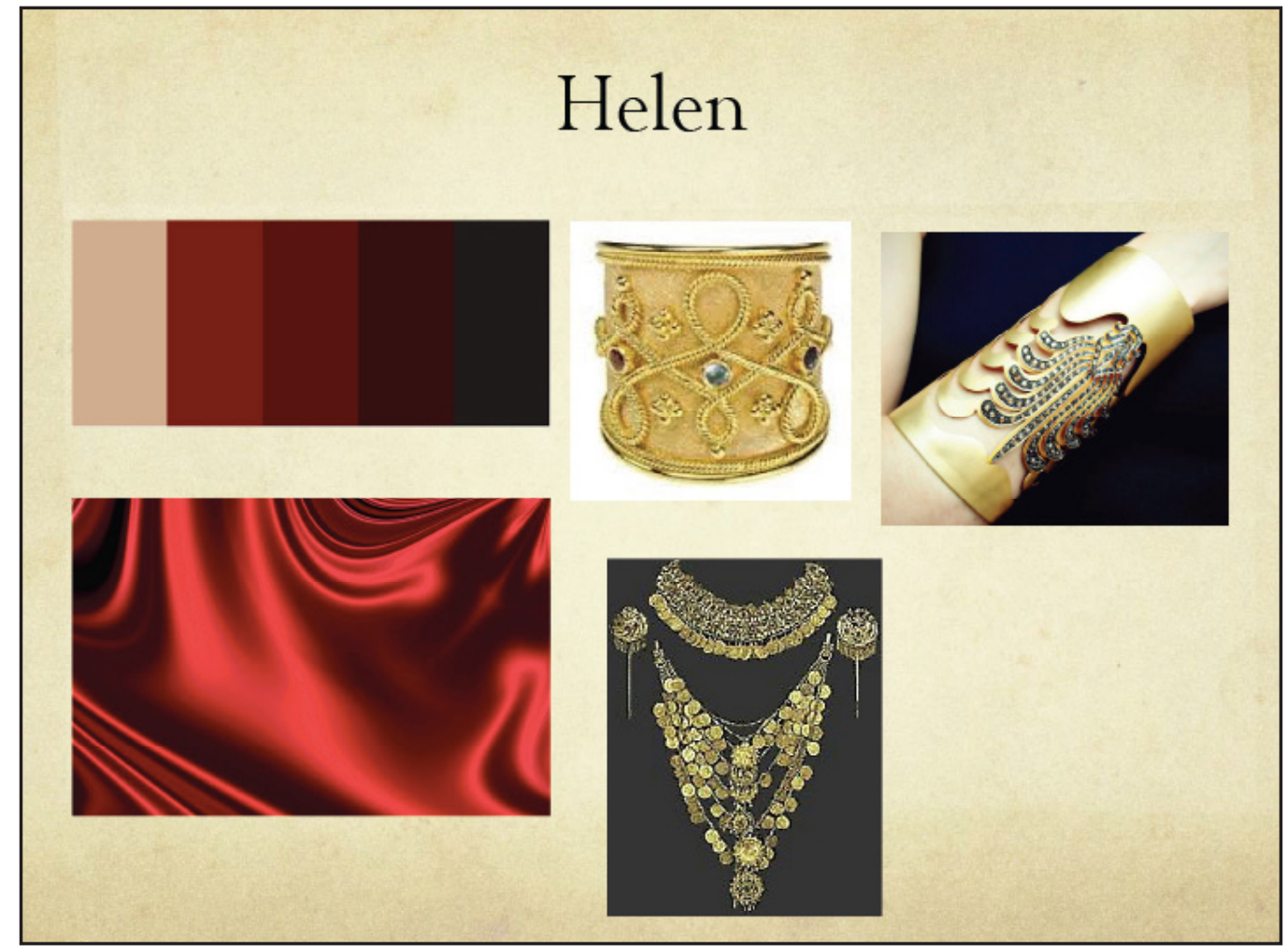

Plate 6A: Color and jewelry research for Helen. 


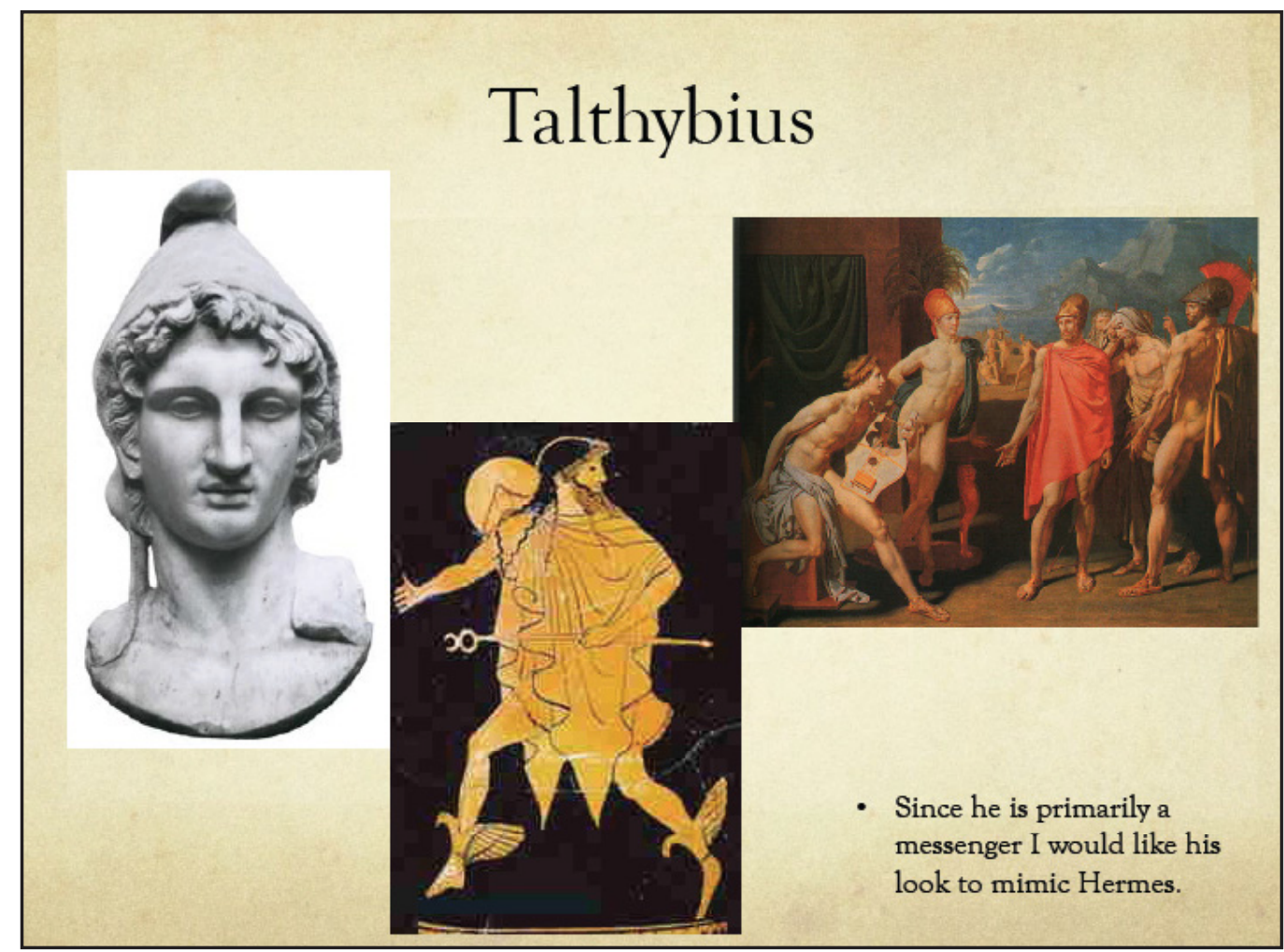

Plate 7: Research images for Talthybius.

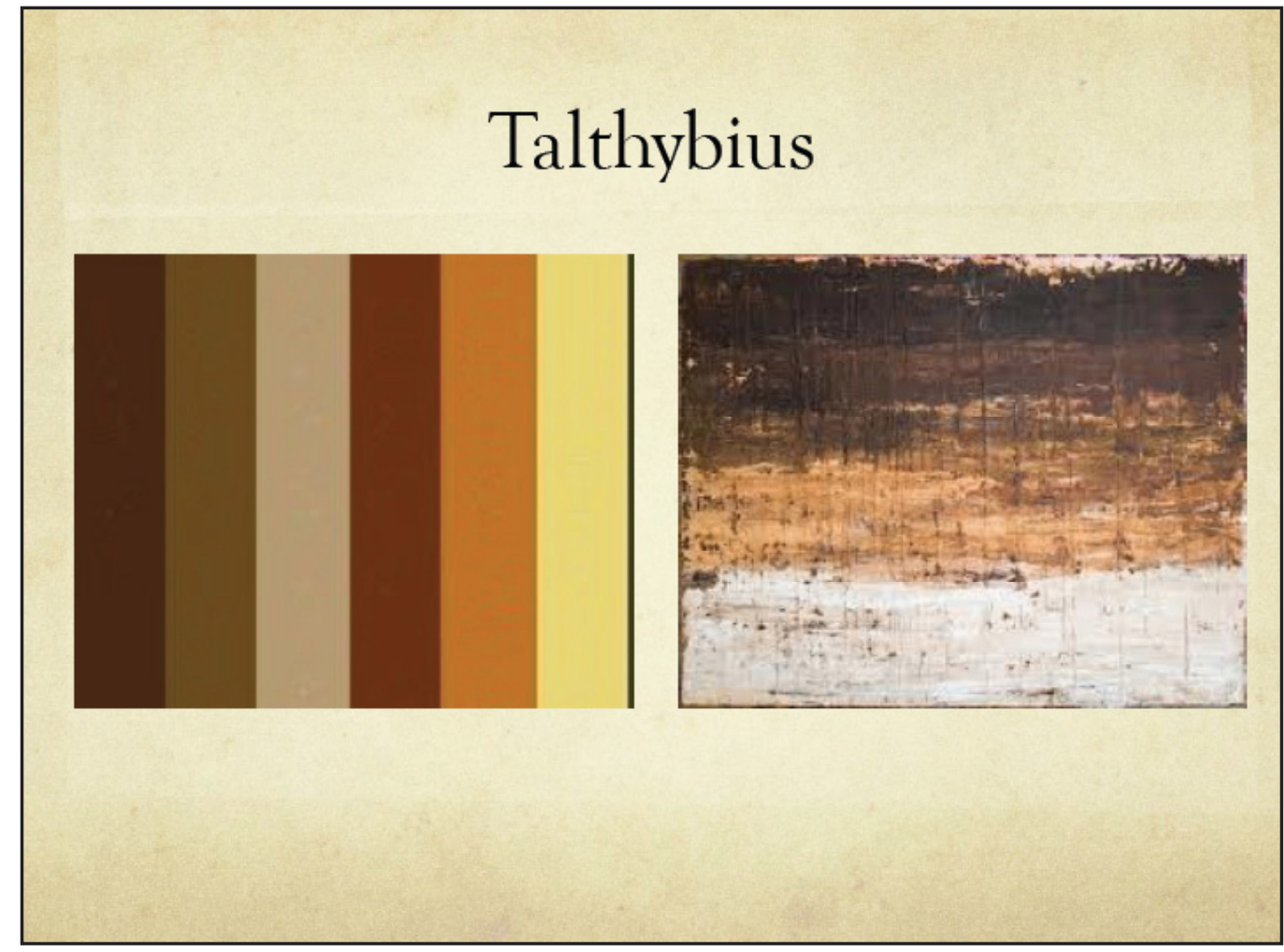

Plate 7A: Color and texture research for Talthybius. 


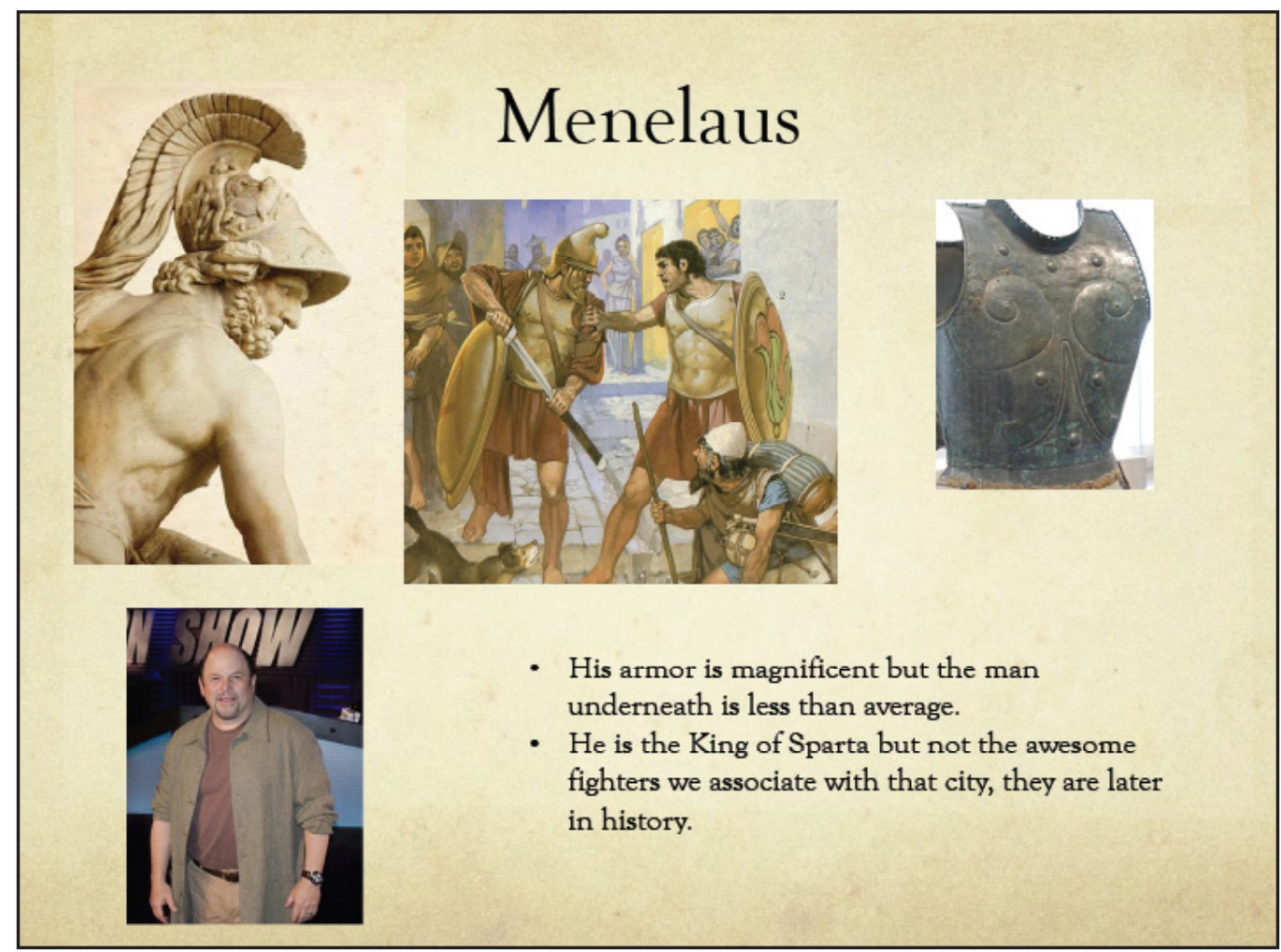

Plate 8: Research images for Menelaus.

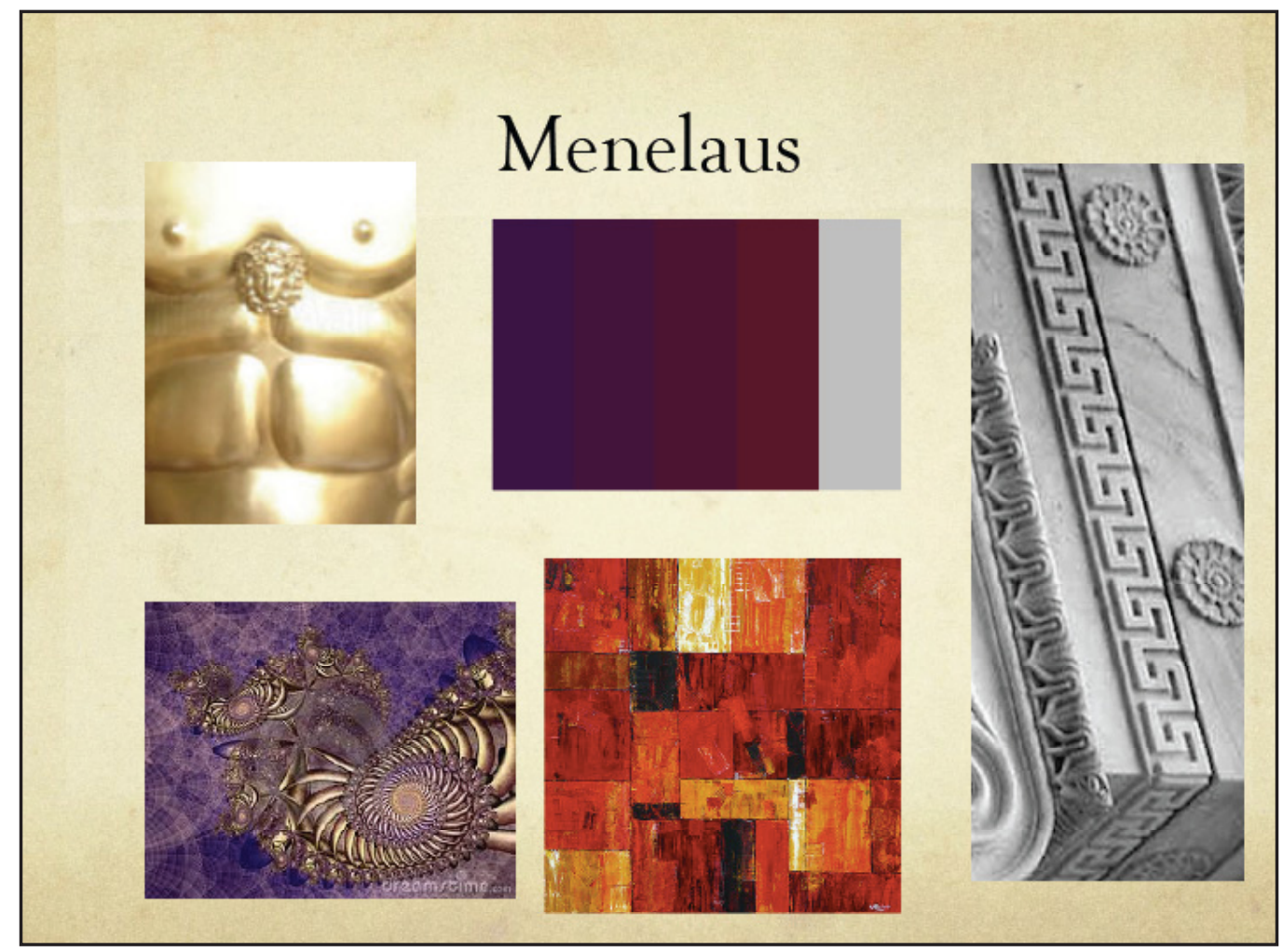

Plate 8A: Color and texture research for Menelaus. 

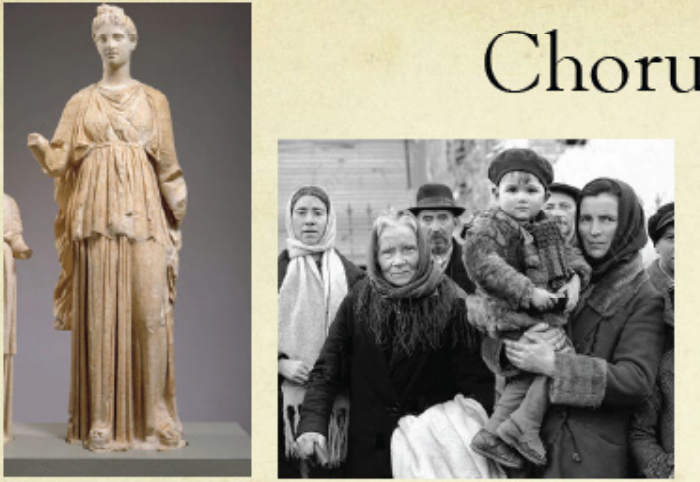

- Cross between modern and Ancient Greek (thrift store shopping for modern items that still flow like the Greek Clothing)

- Controlled color pallet that distinguishes them from the named female characters.
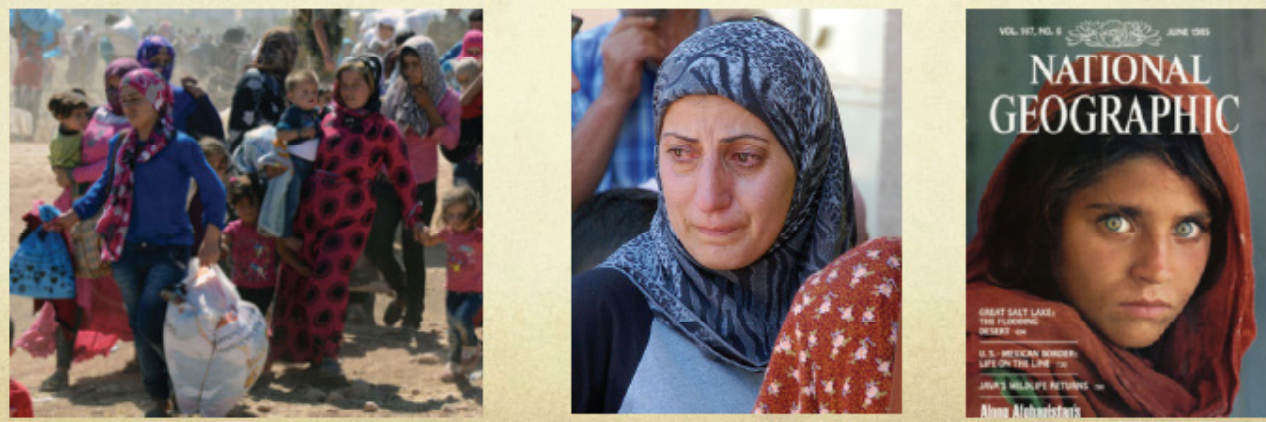

Plate 9: Research images for chorus women.

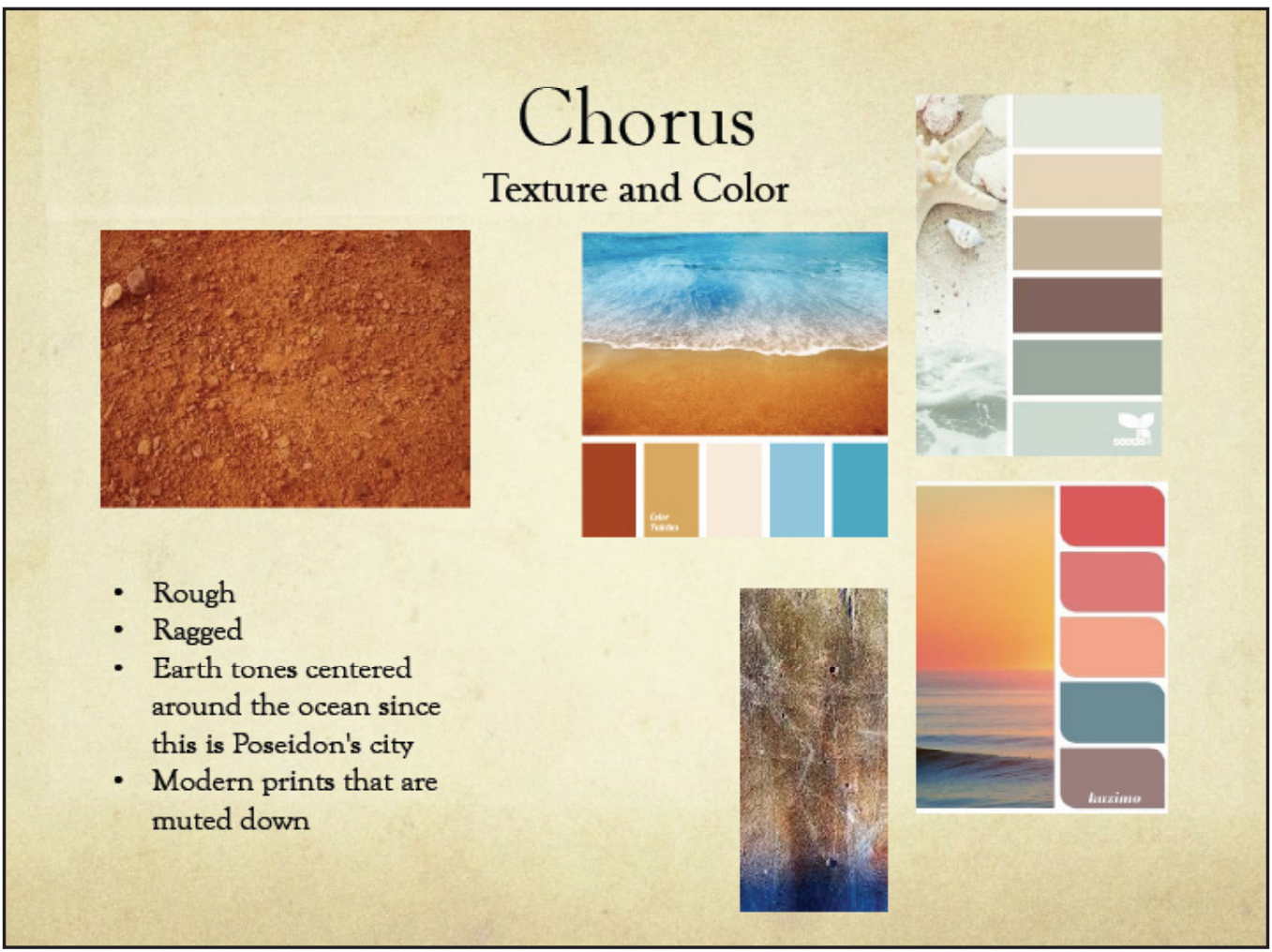

Plate 9A: Color and texture research for the chorus women. 


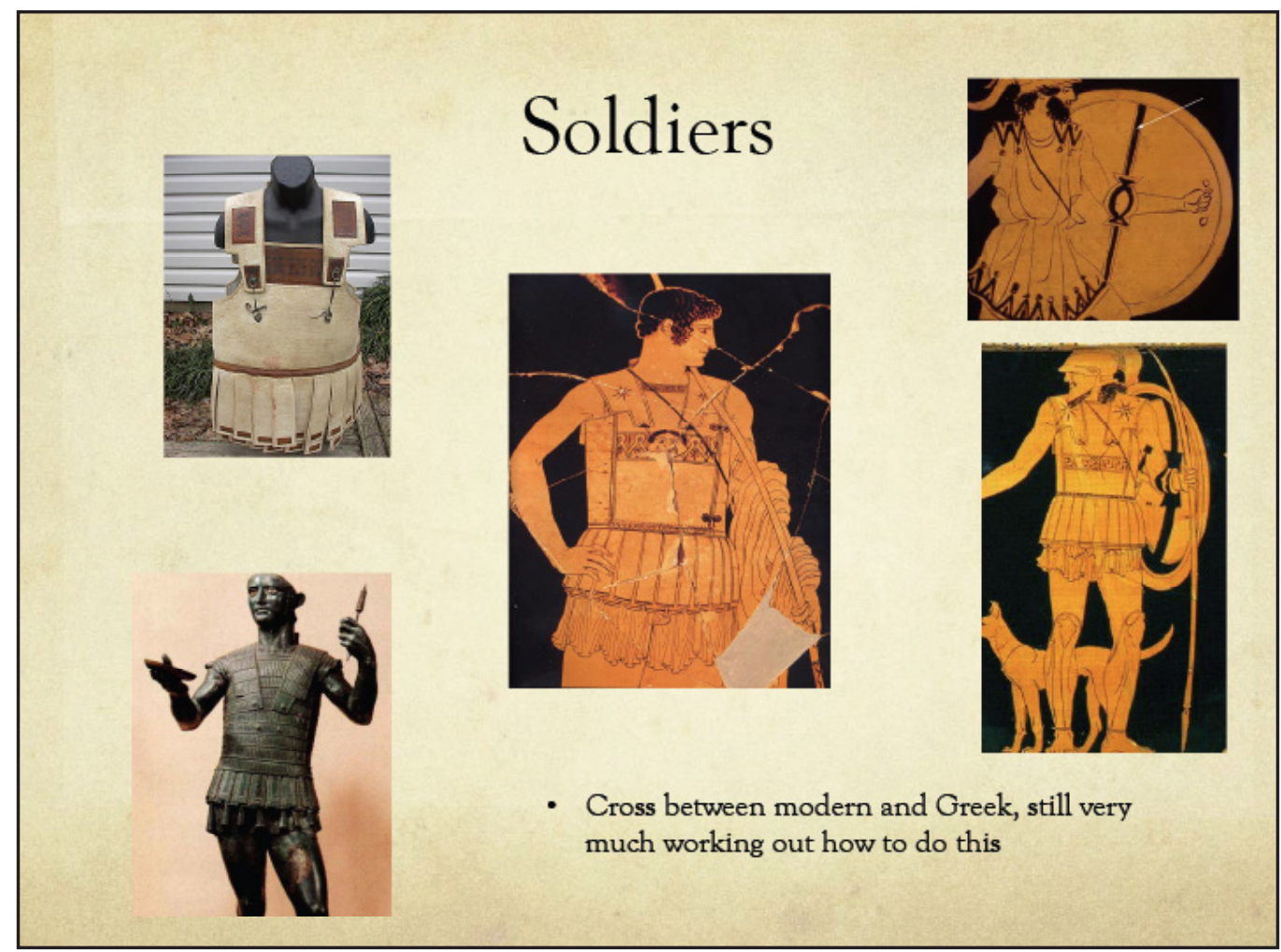

Plate 10: Historical Greek soldier research images.

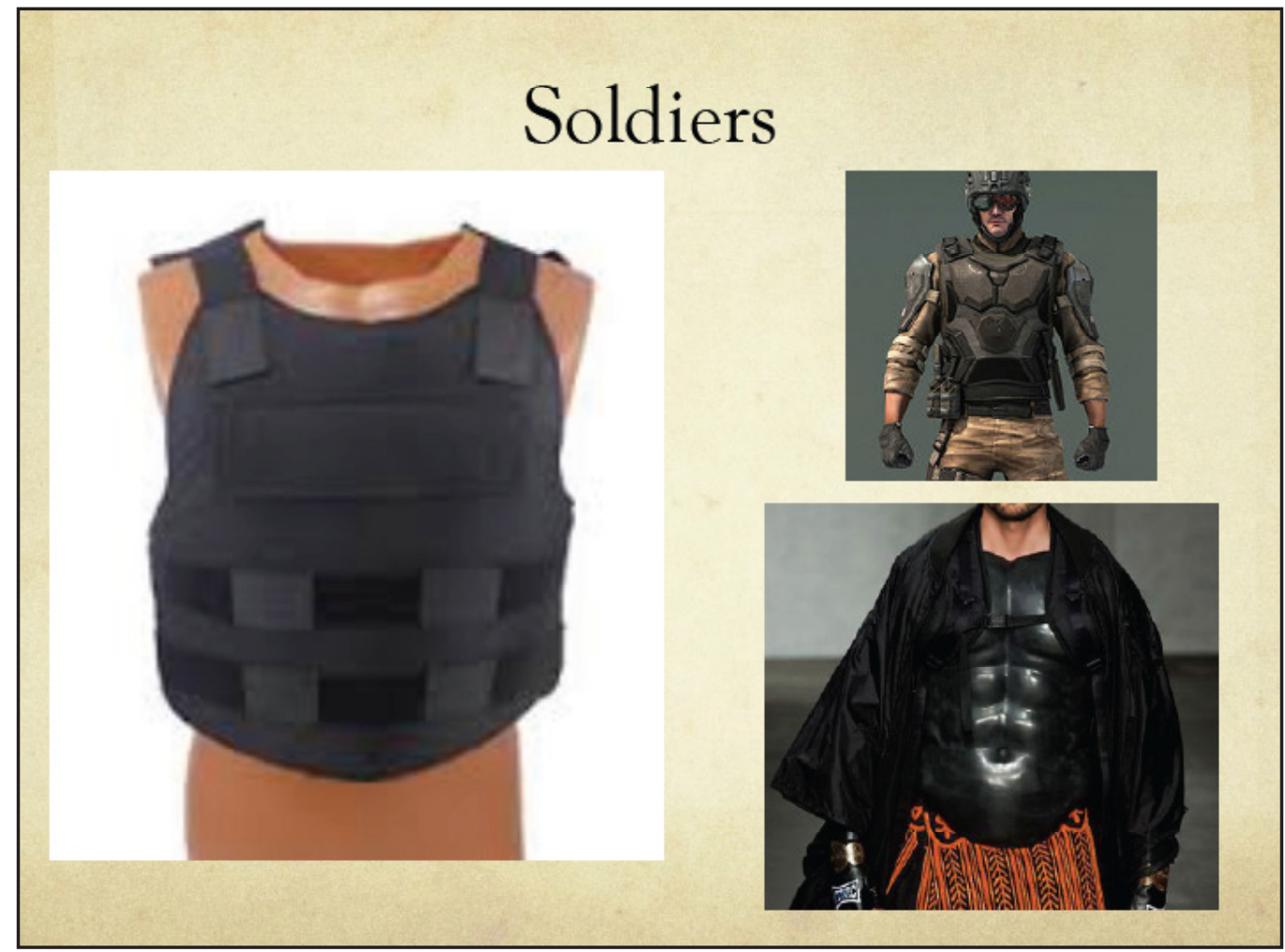

Plate 10A: Modern and high fashion military research. 


\section{APPENDIX II: IMAGE SOURCES FOR RESEARCH PLATES}

- Hecuba Research Images (Plate 1):

○ Left: Greek Lady from Sicily. Munich picture sheets, Fashion of the Centuries, Braun and Schneider. 1858-1898. world4.eu.

- Center: The Atalanta Lekythos. The Cleveland Museum of Art. Leonard C Hanna, 500-490 B.C. Funerary Oil Jug. The Cleveland Museum of Art. clevelandart.org.

- Right: Marble statue of woman wearing a himation. Top 10 famous clothes in ancient Greece. $6^{\text {th }}$ century B.C. Stone sculpture. Ancient History Lists. ancienthistorylists.com.

Hecuba Research Images (Plate 1A):

○ Left: Beach Bliss Living. Beach Color Palettes from the Shore. From the shore tones. Beach Bliss Living. beachblissliving.com.

○ Left center: B-lo and the Red Dirt Squirt. Rawhide \& Velvet. 2012. rawhideandvelvet.com.

- Right center: CyberGod. Beauty of Wilting Flower. Cyber Phoenix. 15 Oct. 2011. cyberphoenix.org.

○ Right: Color Combos, ColorCombo280, Color Scheme Image. colorcombos.com.

- Poseidon Dancer Research Images (Plate 2)

○ Top left: Rodolfoguerreiro. Poseidon under a Cloudy Sky, digital art. Greek Mythology Pantheon. 2013. greek-mythology-pantheon.com

○ Top center: Bangarra Dance Theatre. BROLGA. Bangarra, 2001. Photograph. bangarra.com.au.

○ Top right: Gunesekera, Romesh. Reef. Freytag \& Berndt. Unionsverlag, 2015. Book cover.

○ Bottom left: Minoan three handled Jar. 1600-1500 B.C. Vasilki Ware. Looking at Ancient Pottery (Minoan), ritaroberts.wordpress.com. 
○ Bottom center: Milles, Carl. Greek God Poseidon. 1931. Marble Statue, Copenhagen, Denmark.

- Bottom right: DallasCrazy48. Purple Night Sky color palette. Sherwin-Williams Color Snap. snapyourcolors.com.

Child Research Images (Plate 3)

○ Right: Ellis \& Walery. Charles Hayden Coffin, 1898. Painting, Magnolia box. magnoliabox.com.

- Right center: Boy in Chiton. History of Fashion: Greece. The Bertho Times. 27 Aug. 2015. theberthotimes.blogspot.com.

o Left center: Statue of Man with a Chiton. Chiton. Wikipedia. wikipedia.org

○ Left: Color Combos, ColorCombo280, Color Scheme Image. colorcombos.com.

- Cassandra Research Images (Plate 4)

- Left: De Morgan, Evelyn. Cassandra. De Morgan Centre. The Athenaeum. 1898. the-athenaeum.org.

- Center: Lester, Katherine and Kerr, Rose Netzorg. Ionic chiton. 1967. Make it a Tunic! KET distant learning, dl.ket.org.

○ Top right: Lester, Katherine and Kerr, Rose Netzorg. Ionic chiton. 1967. Make it a Tunic! KET distant learning, dl.ket.org.

○ Bottom right: Lester, Katherine and Kerr, Rose Netzorg. Bound Ionic chiton. 1967. Make it a Tunic! KET distant learning, dl.ket.org.

- Cassandra Research Images (Plate 4A)

○ Top left: Villa, Jose. Once Wed. Photograph, fabulous bridal fabrics. www. Weddbook.com.

○ Top center: Palo_ok. White snake skin texture. shutterstock.com

○ Top right: Burckhardt, Marc. Cassandra, Acrylic and oil on wood panel. Marc Burckhardt Art. marcburckhardt.com.

○ Bottom left: Felipe White. Snake skin background two, atextures.com 
○ Bottom right: Exotic Colorful Expressions. Color palette wildlife expressions, Green lizard tones. Pinterest, n.d.

Andromache Research Images (Plate 5)

○ Left: Girl in Chiton. Munich picture sheets, Fashion of the Centuries, Braun and Schneider. 1858-1898. world4.eu.

- Center: The death of Astyanax. n.d. engraving, en.academic.ru.

- Right: Priestess of Demeter. Munich picture sheets, Fashion of the Centuries, Braun and Schneider. 1858-1898. world4.eu.

- Andromache Research Images (Plate 5A)

○ Right: Weagain. Punk Multi-layered Shoulder Jewelry. Digital image. Ebay. n.p., n.d., ebay.com.

- Center: Prue Lala. Body Jewelry. Digital Image. Sky-liner. sky-lyner.blogspot. com.

○ Left: Blue Bergitt. Sacred Nature. ColorWorld's Fall Winter. 2013. bluebergitt. wordpress.com.

- Helen Research Images (Plate 6)

○ Top left: De Morgan, Evelyn. Helen of Troy, Fine Art America. 1898. Oil On Canvas. fineartamerica.com.

○ Top right: David, Jacques-Louis. The Loves of Paris and Helen. 1788. Oil On Canvas, Musee du Louvre, Paris.

- Right: And that's a Wrap. Ancient Greek woman. The fabric network. info.fabrics. net.

- Bottom: How to put on a Chiton, Roman Fashion, 1000 Atmospharen. 1000atmosphaeren.at.

- Helen Research Images (Plate 6A)

○ Top left: PuddingFiddles, Vampyrism. 5 Spooky Color Palettes. 2012. blog. psprint.com. 
- Top center: Rope swirl wide band ring. Digital image. Athena’s Treasures. n.p., n.d., athenas-treasures.com.

○ Top right: Vassiliki “Anthemion” Gold Cuff. Digital image. n.p., n.d., polyvore. com.

- Bottom left: Admin, Silk fabric texture. Texture online. 2010. textureonline.com.

○ Bottom right: Gilded decoration of Attica. Digital image. 2016. jewellerymuseum. ru.

- Talthyibus Research Images (Plate 7)

o Left: Youth wearing a Phrygian cap. Fitzwilliam Museum, Encyclopedia Britannica, $4^{\text {th }}$ century. britannica.com.

○ Center: Hermes Vase. Metropolitan Museum, Theoi Greek Mythology, 500-450 B.C. theoi.com.

○ Right: Ingres, Jean Auguste Dominique. Ambassadors of Agamemnon in the Tent of Achilles. Ecole des Beaux-Arts, Paris. 1800. Painting. An introduction to Nineteenth Century Art. 19thcenturyart-facos.com.

- Talthyibus Research Images (Plate 7A)

○ Left: Color Combos, ColorCombo288, Color Scheme Image. colorcombos.com.

- Right: Lowndes, Marta. Fugue 6 op 92. Painting on canvas. Amazon. amazon.com.

- Menelaus Research Images (Plate 8)

- Top left: Menelaus Supporting the Body of Patroclus. Loggia dei Lanzi, Timur Kulgrin. Photographer. Encyclopaedia Bertannica, University of Oxford, $17^{\text {th }}$ century. britannica.com.

- Top center: The Ancient Greeks, 22 November 2011. Historical Warrior Illustration Series Part XVII. thelosttreasurechest.wordpress.com.

○ Top right: Greek Breastplate, Ancient Greek Armor, Ancient Greece. sites.google. com/a/cbmsonline.net/greece-pink. 
○ Bottom left: Jason Alexander. 3 June 2015. Photograph, Daily Mail. dailymail.co.uk

- Menelaus Research Images (Plate 8A)

○ Top left: Roman Medieval Brass Muscle Armor Chestplate. Digital Image. n.d., Bonanza. bonanza.com.

○ Top right: Color palettes, Mars colors color palette, color-hex. color-hex.com.

○ Bottom left: Jkerrigan. Royal Colors. n.d. Dreamstime. dreamstime.com.

○ Bottom right: Autumn Sensation. n.d. Acrylic on canvas, Simons gallery. simonsgallery.com.

o Right: Greek key decorative border. Decorating with the Greek Key pattern, The Kellogg Collection. November 2014. kelloggcollection.com.

- Chorus Research Images (Plat 9)

○ Top left: Hemingway, Colette. Marble funerary statues of a maiden and a little girl. Women in Classical Greece. 320 B.C. stone sculpture. The Met Museum. metmuseum.org.

○ Top right: WWII Belgian Refugees. Children in History, La Gleize, Belgian, 12 Aug. 2014. histclo.com.

○ Bottom left: Cassie, Webber. Syrian children who fled from ISIS. Chiangrai Times, 2 April 2016. chiangraitimes.com.

○ Bottom center: Sameen. Lebanon hosts the largest number of refugees per capita. List 25. 22 August 2015. list25.com.

○ Bottom right: Steve McCurry. Afghan Girl. 1984. National Geographic Magazine. Cover Photo.

Chorus Research Images (Plate 9A)

○ Left: B-lo and the Red Dirt Squirt. Rawhide \& Velvet. 2012. rawhideandvelvet. com. 
- Top center: Color Palettes Color Palette \#205. Beach Color. Color Palettes. colorpalettes.net.

- Top right: Beach Bliss Living, Beach Color Palettes from the Shore. From the shore tones. Beach Bliss Living. beachblissliving.com.

o Bottom center: Rough Texture, Toasto free stock photos. 2010. toasto.com.

○ Bottom right: Noblitt, Caitlin. Sunset Color palette, That's Pinteresting! Nautical Inspiration. 12 September 2015. impulsecrafter.blogspot.com.

- Soldiers Research Images (Plate 10)

- Top left: Greek Armor Used in the Movie Alexander and battles b.c. series. Digital image. 13 March 2012. antiquesnavigator.com.

○ Top right: Menelaos vase, Museume of Art, Toledo (OH), Classical Art Research Centre, University of Oxford, mid $5^{\text {th }}$ century. beazley.ox.ac.uk.

- Center: Achilles Painter name vase. Vatican Museum. M. Tiverios, photographer. Classical Art Research Centre, University of Oxford, mid $5^{\text {th }}$ century. beazley. ox.ac.uk.

○ Bottom left: Mars of Todi. Late 5th or early 4th century B.C., hollow-cast bronze, Gregorian Etruscan Museum, Vatican Museums.

○ Bottom right: Warrior departing for battle. 450 B.C. Painted Vase. Sun of Vergina- A Greek symbol, History of Macedonia. history-of-macedonia.com.

- Soldiers Research Images (Plate 10A)

- Top left: Concealed Body Armor Level IIIA. Tatical Scorpion Gear. 2015, tacticalscorpiongear.com.

○ Top right: Urban warrior. 2015. Digital image. KTZ. elle.com. Bottom left: Delmeule, Camille. Modern combat-Africa soldier. 3D Digital art, ARTstation. artstation.com. 


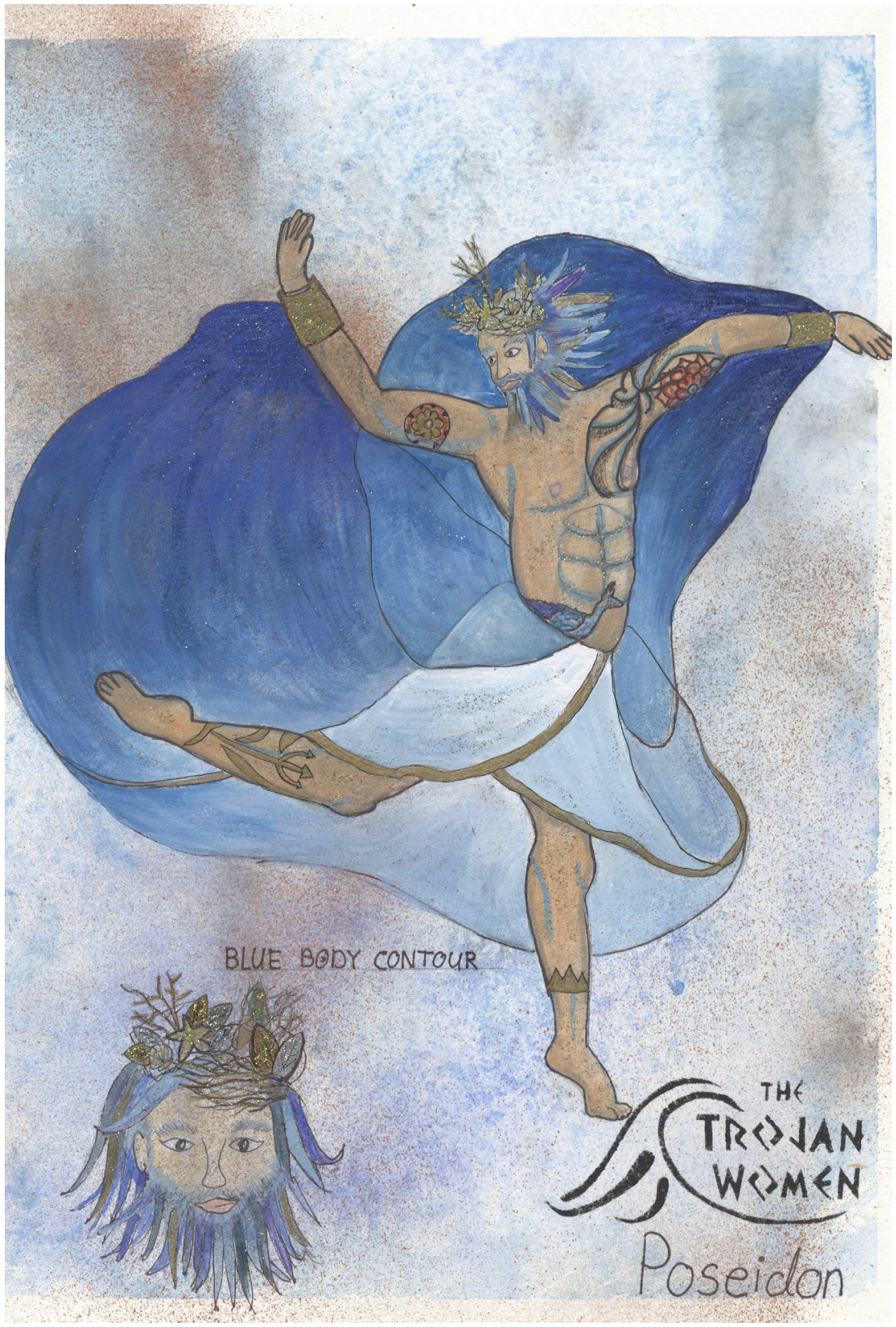

Poseidon, final rendering.

Lorich, Cody K. Poseidon. 2015. Watercolor \& Marker. West Virginia University School of Theatre \& Dance, Morgantown, WV. Digital Image. 


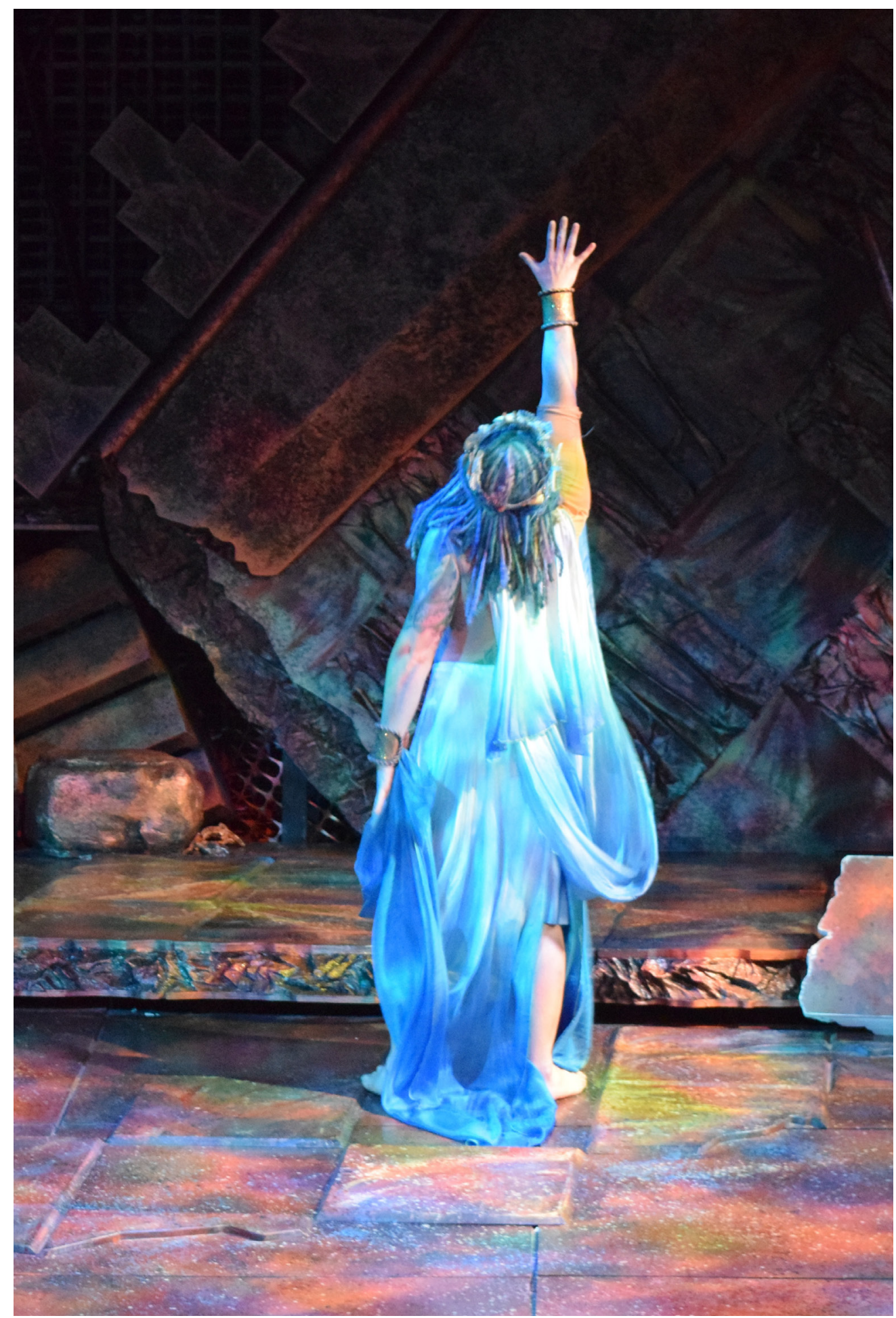

Poseidon Dancer (Michael Morris)

Lorich, Cody K. Poseidon. 2016. Photograph. West Virginia University School of Theatre \& Dance, Morgantown, WV. 

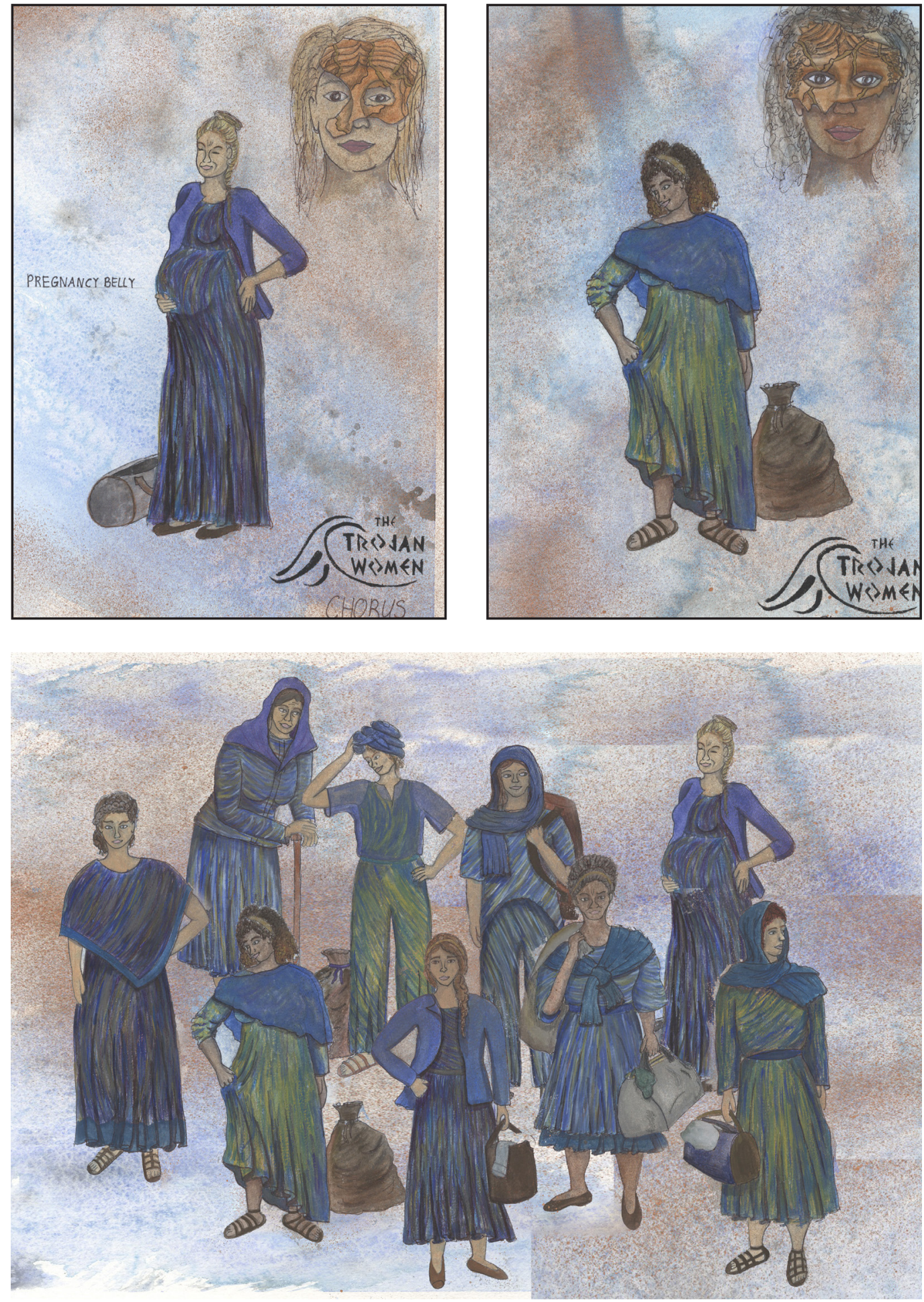

Chorus Women, final renderings.

Lorich, Cody K. Chorus Women. 2015. Watercolor \& Marker. West Virginia University School of Theatre \& Dance, Morgantown, WV. Digital Image 


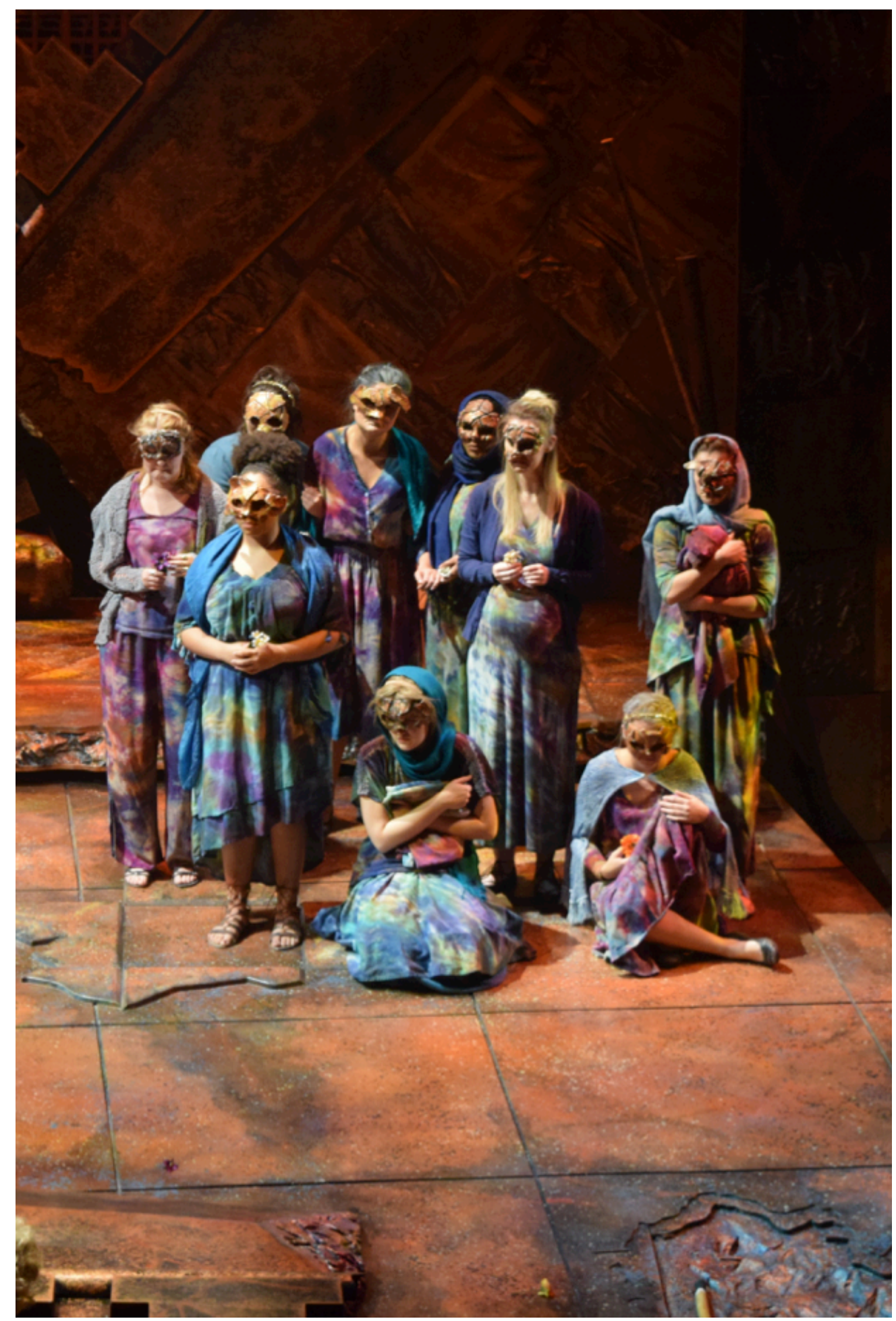

Chorus Women (Abigail Cyphert, Brianna Bowers, Briana Gause, Deja Elliott, Elize Rucker, Katelyn Fauss, Monica Hanigan, Nativa Kesecker and Taylor Morgan)

Lorich, Cody K. Chorus Women. 2016. Photograph. West Virginia University School of Theatre \& Dance, Morgantown, WV. 


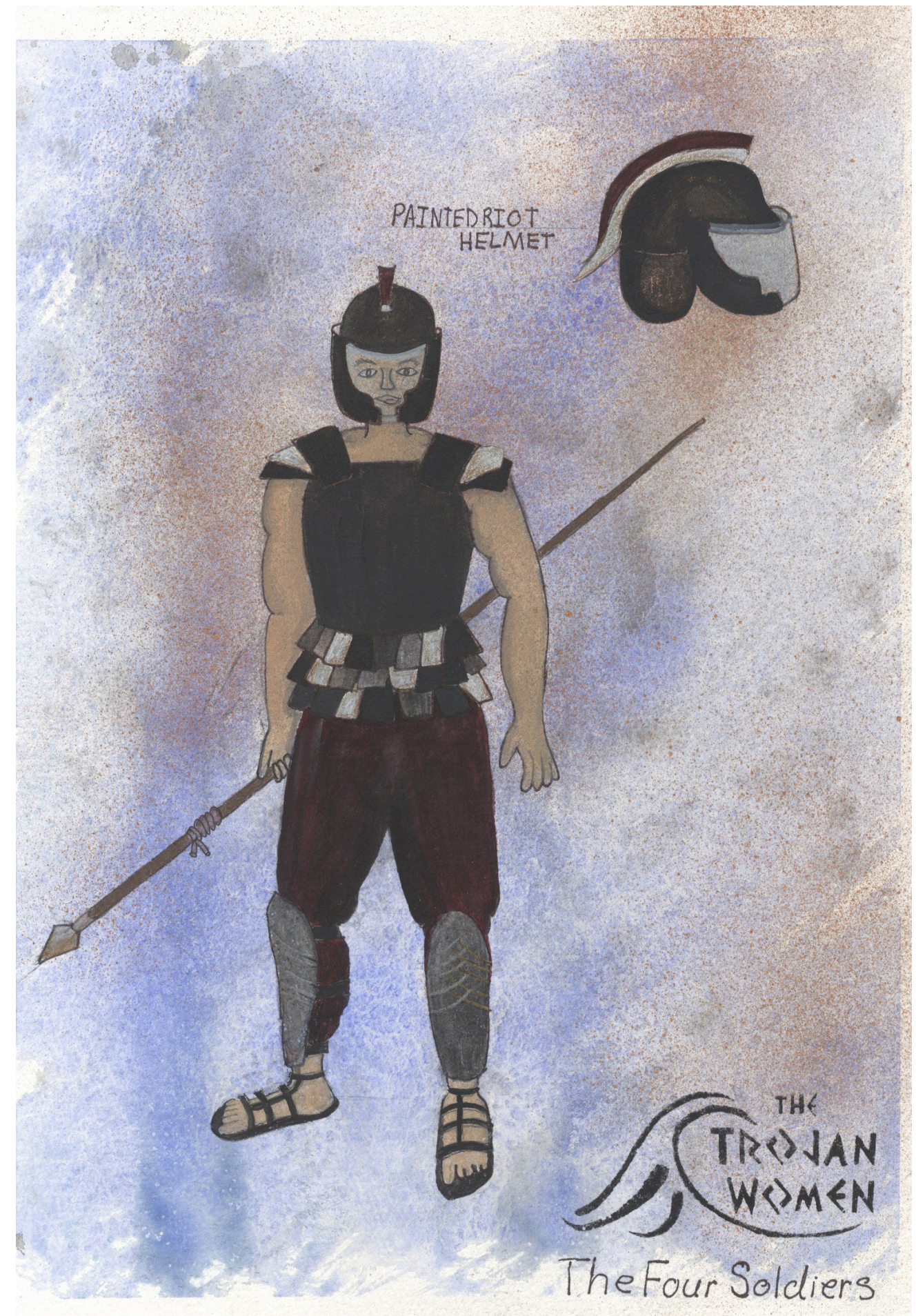

The Four Soldiers, final rendering.

Lorich, Cody K. The Four Soldiers. 2015. Watercolor. West Virginia University School of Theatre \& Dance, Morgantown, WV. Digital Image. 


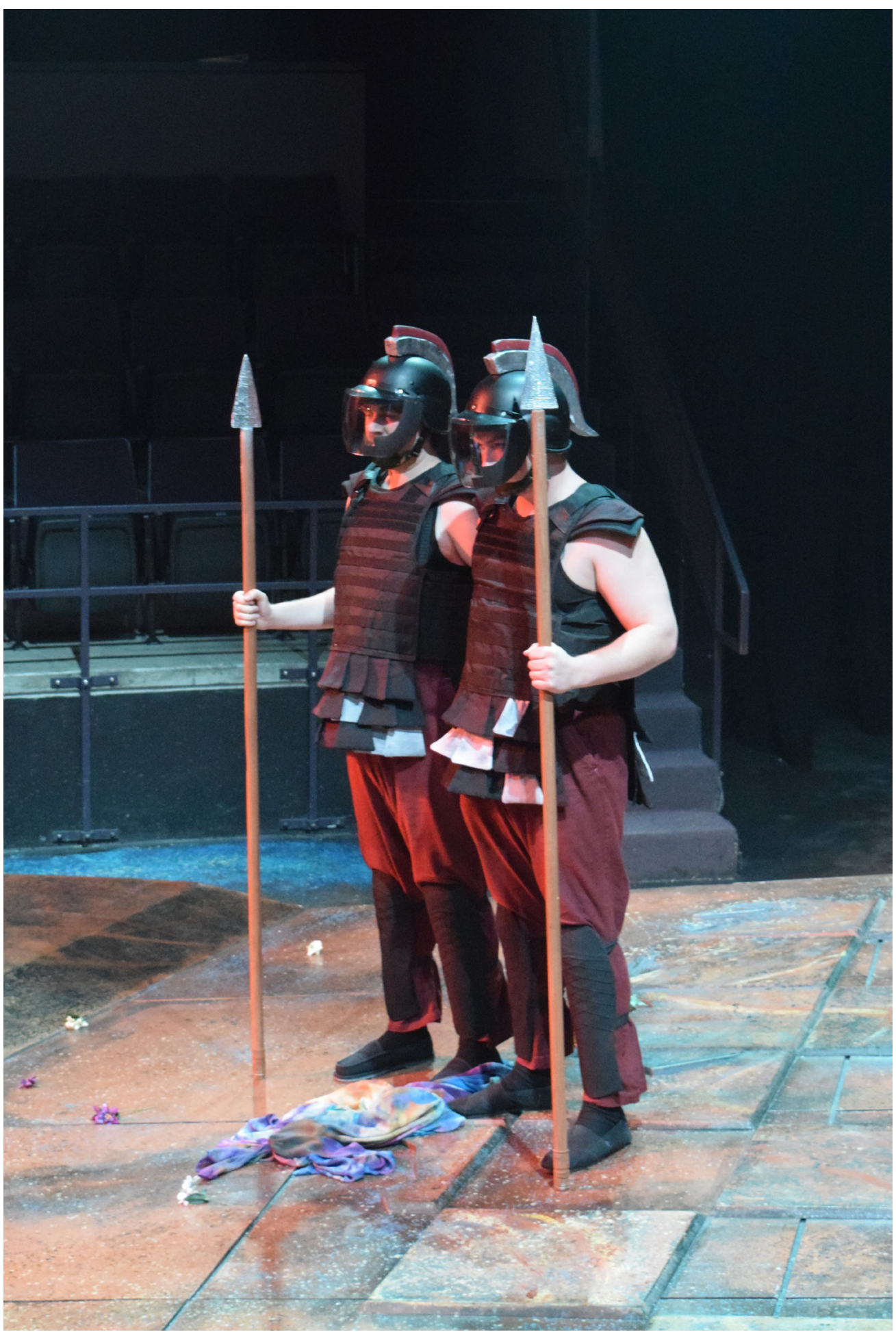

Two Soldiers (Joshua Dieter and Matthew Clark)

Lorich, Cody K. Two Soldiers. 2016. Photograph. West Virginia University School of Theatre \& Dance, Morgantown, WV. 


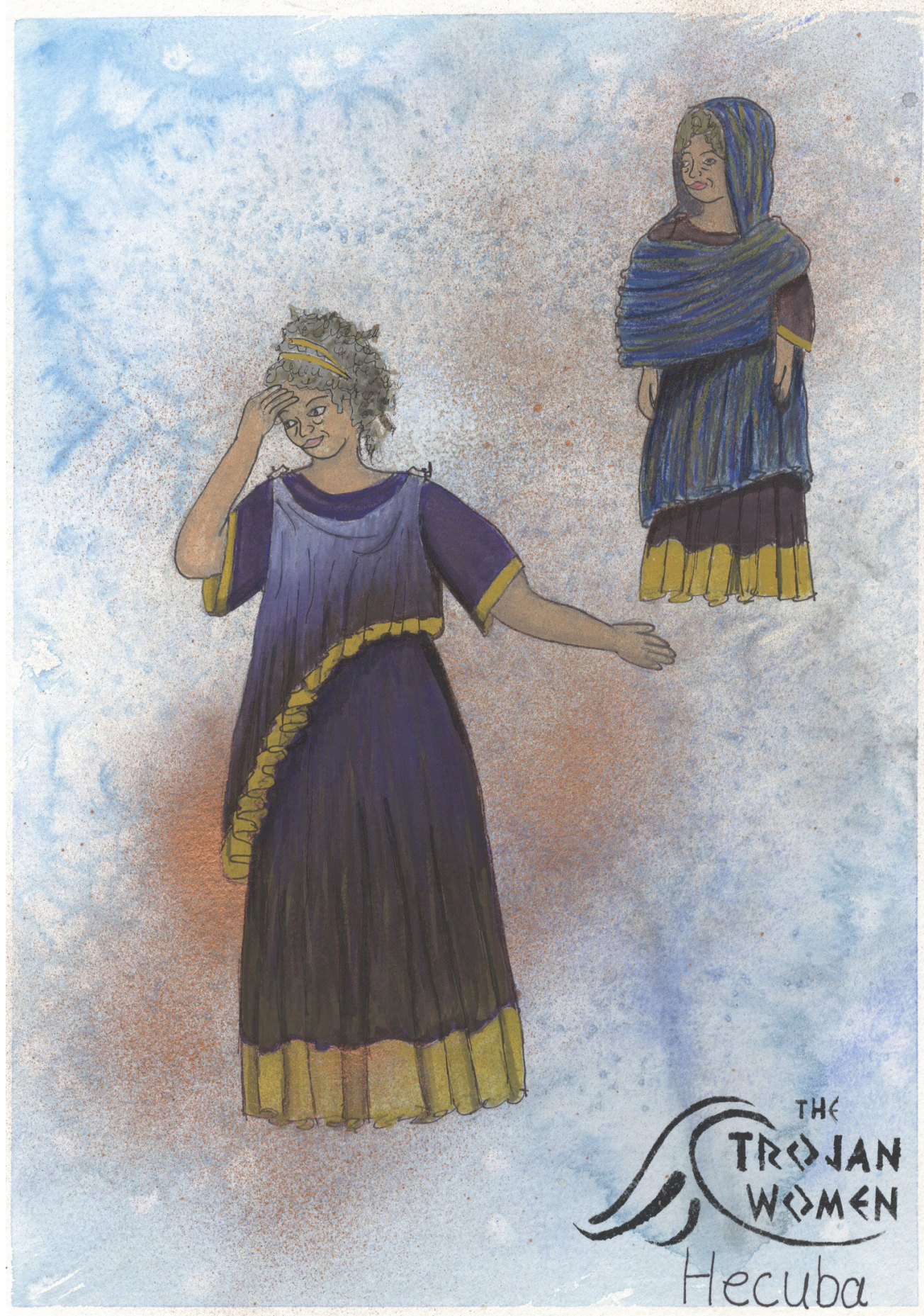

Hecuba, final rendering.

Lorich, Cody K. Hecuba. 2015. Watercolor \& Marker. West Virginia University School of Theatre \& Dance, Morgantown, WV. Digital Image. 


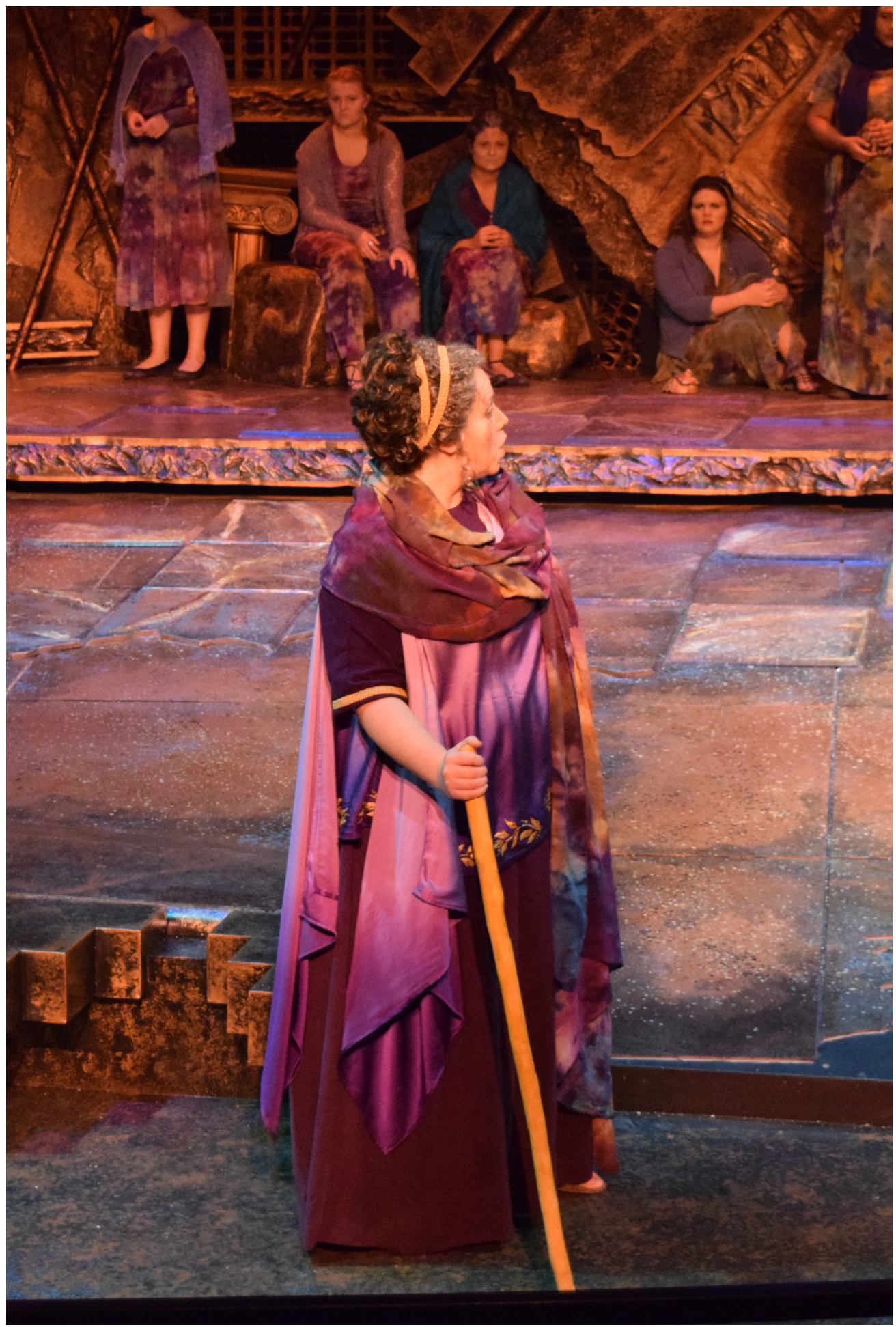

Hecuba (Madeline Hintz)

Lorich, Cody K. Hecuba. 2016. Photograph. West Virginia University School of Theatre \& Dance, Morgantown, WV. 


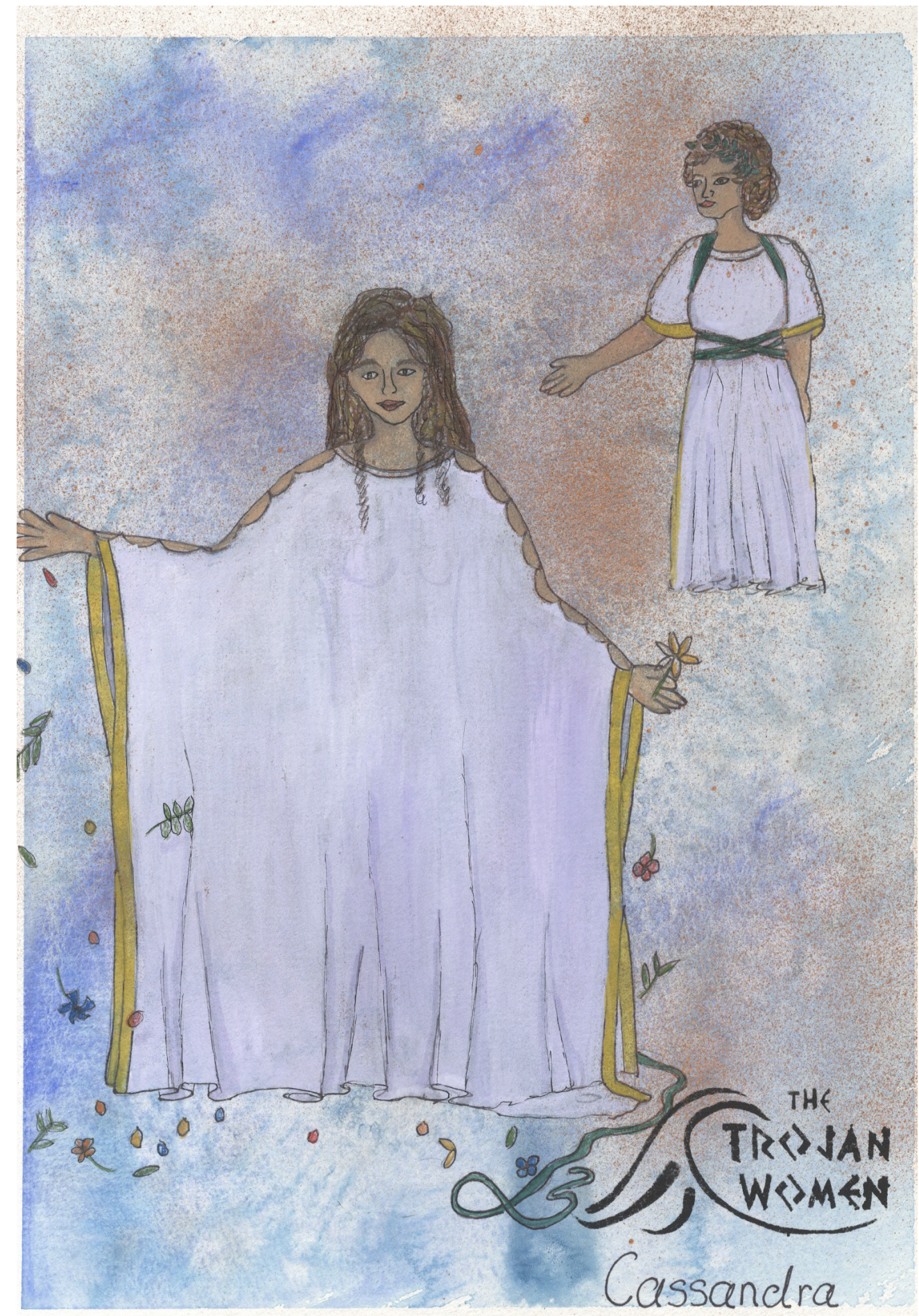

Cassandra, final rendering.

Lorich, Cody K. Cassandra. 2015. Watercolor \& Marker. West Virginia University School of Theatre \& Dance, Morgantown, WV. Digital Image. 


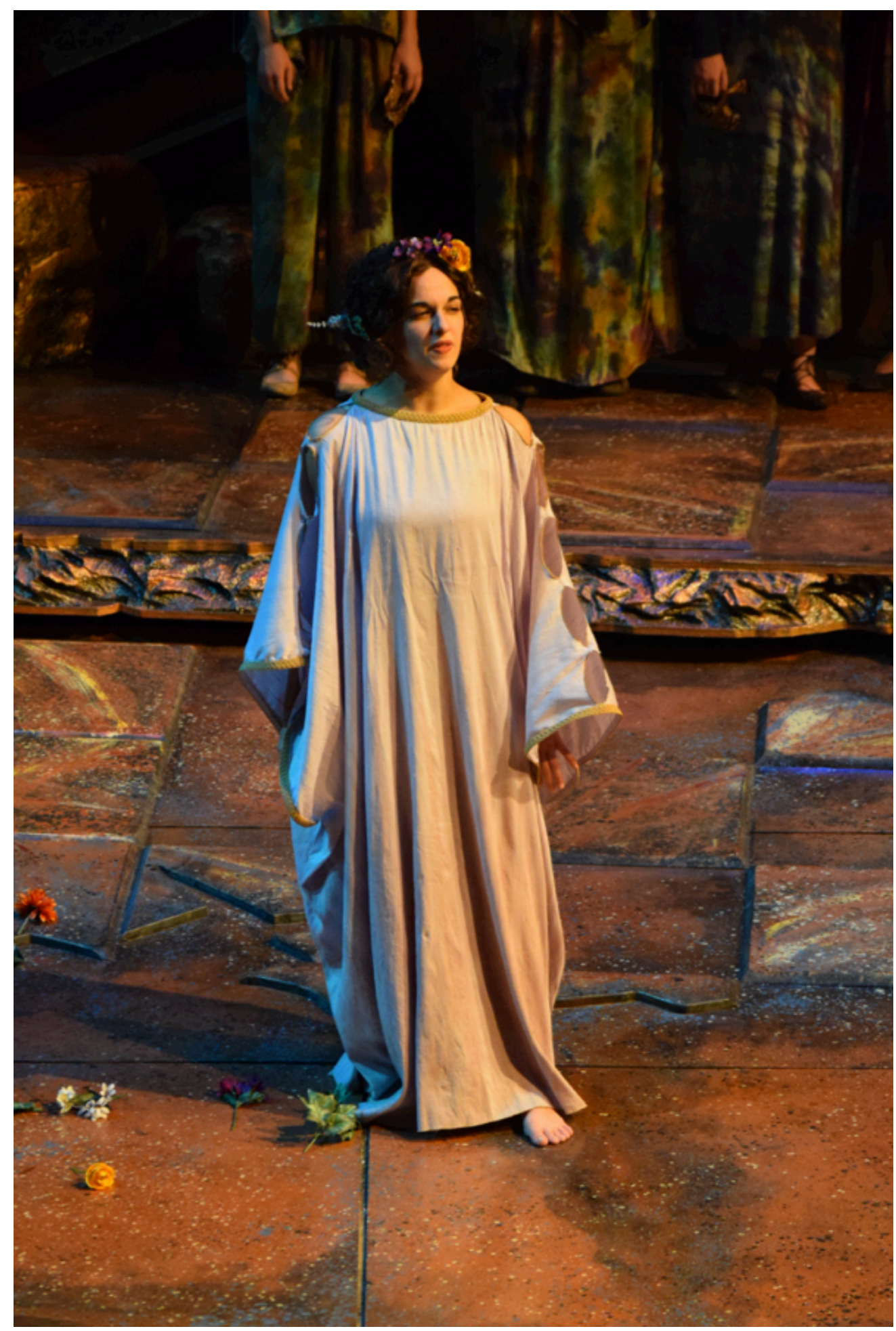

Cassandra (Rachel Moore)

Lorich, Cody K. Cassandra. 2016. Photograph. West Virginia University School of Theatre \& Dance, Morgantown, WV. 


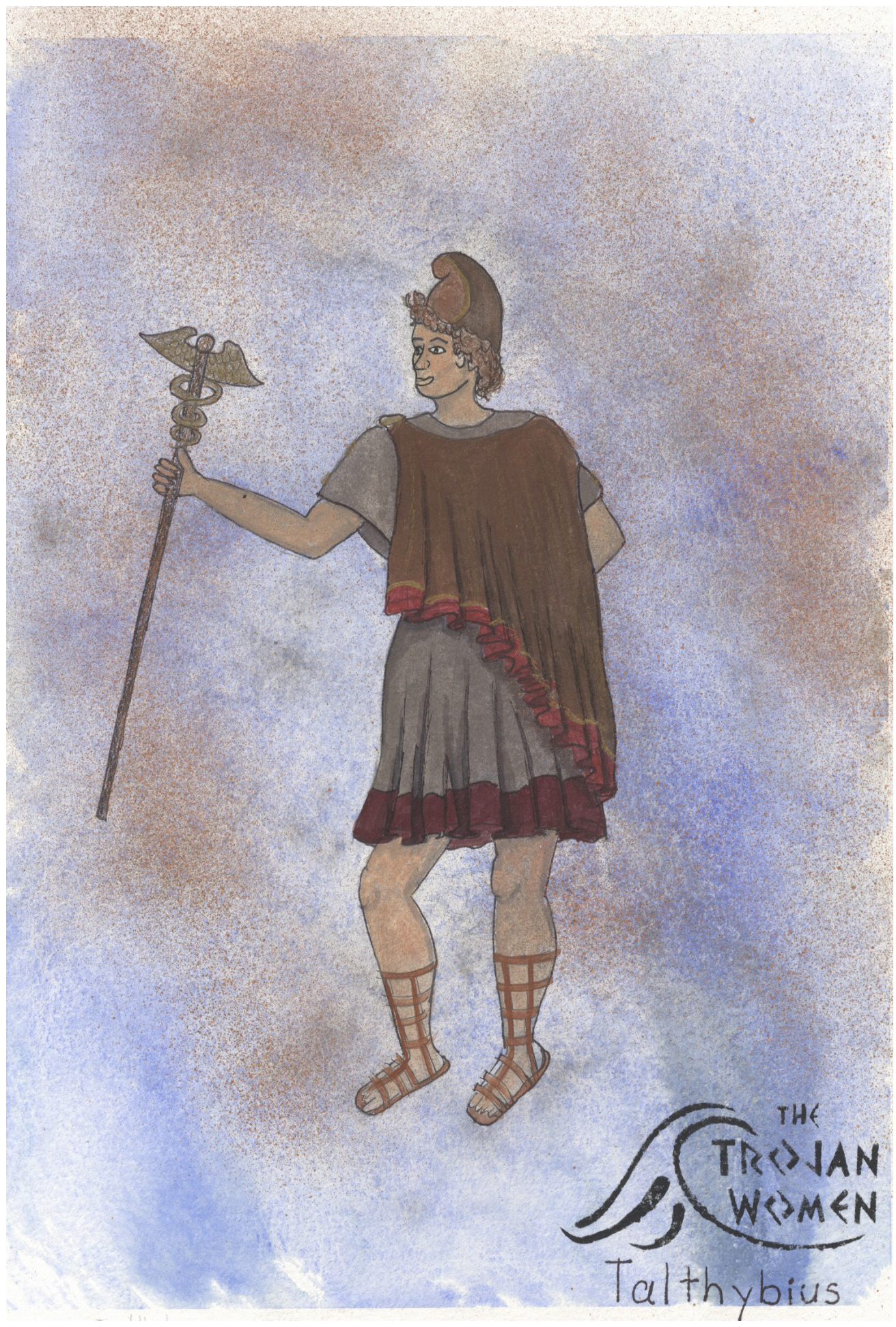

Talthybius, final rendering.

Lorich, Cody K. Talthybius. 2015. Watercolor \& Marker. West Virginia University School of Theatre \& Dance, Morgantown, WV. Digital Image. 


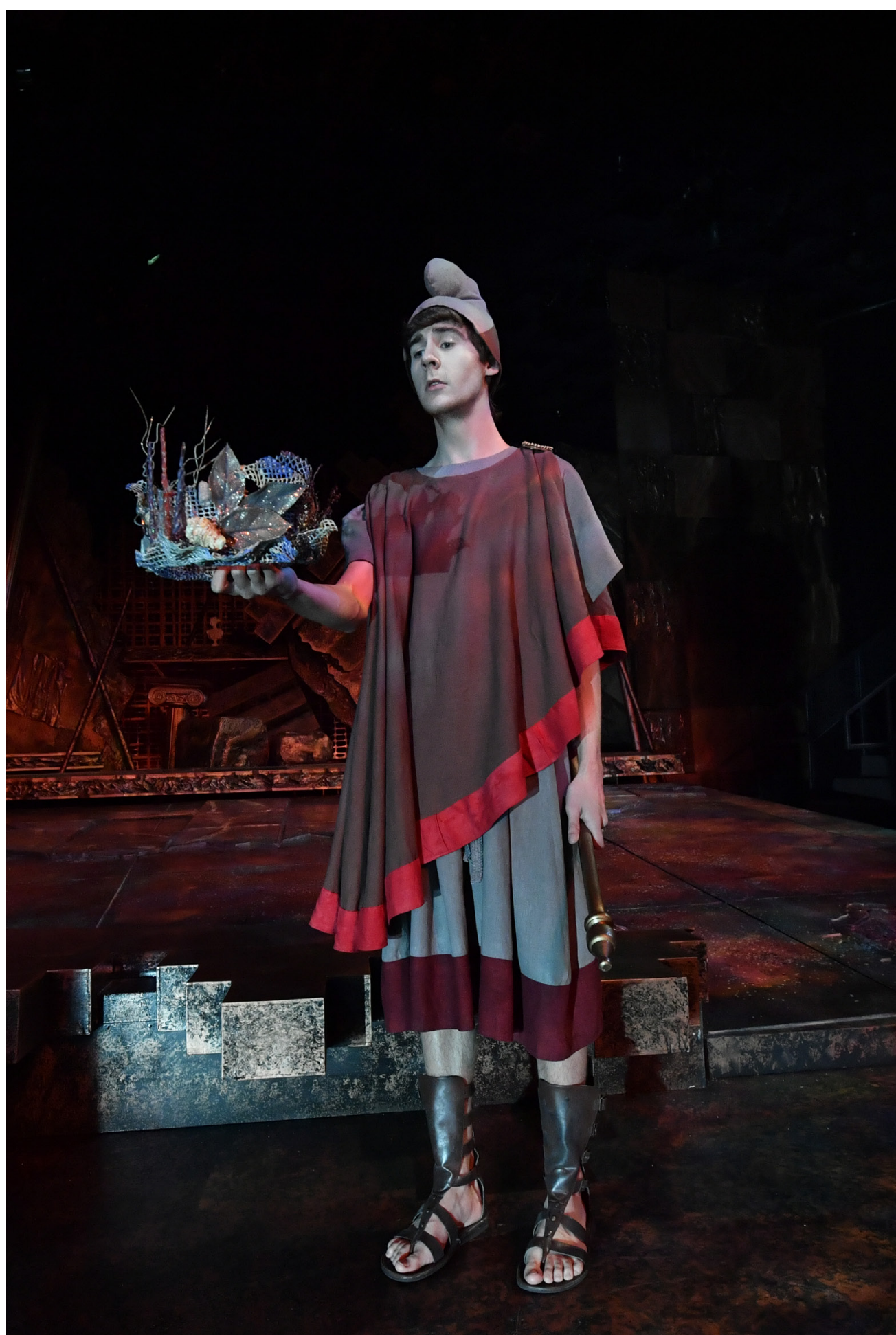

Talthybius (Zach Powers)

Lorich, Cody K. Talthybius. 2016. Photograph. West Virginia University School of Theatre \& Dance, Morgantown, WV. 


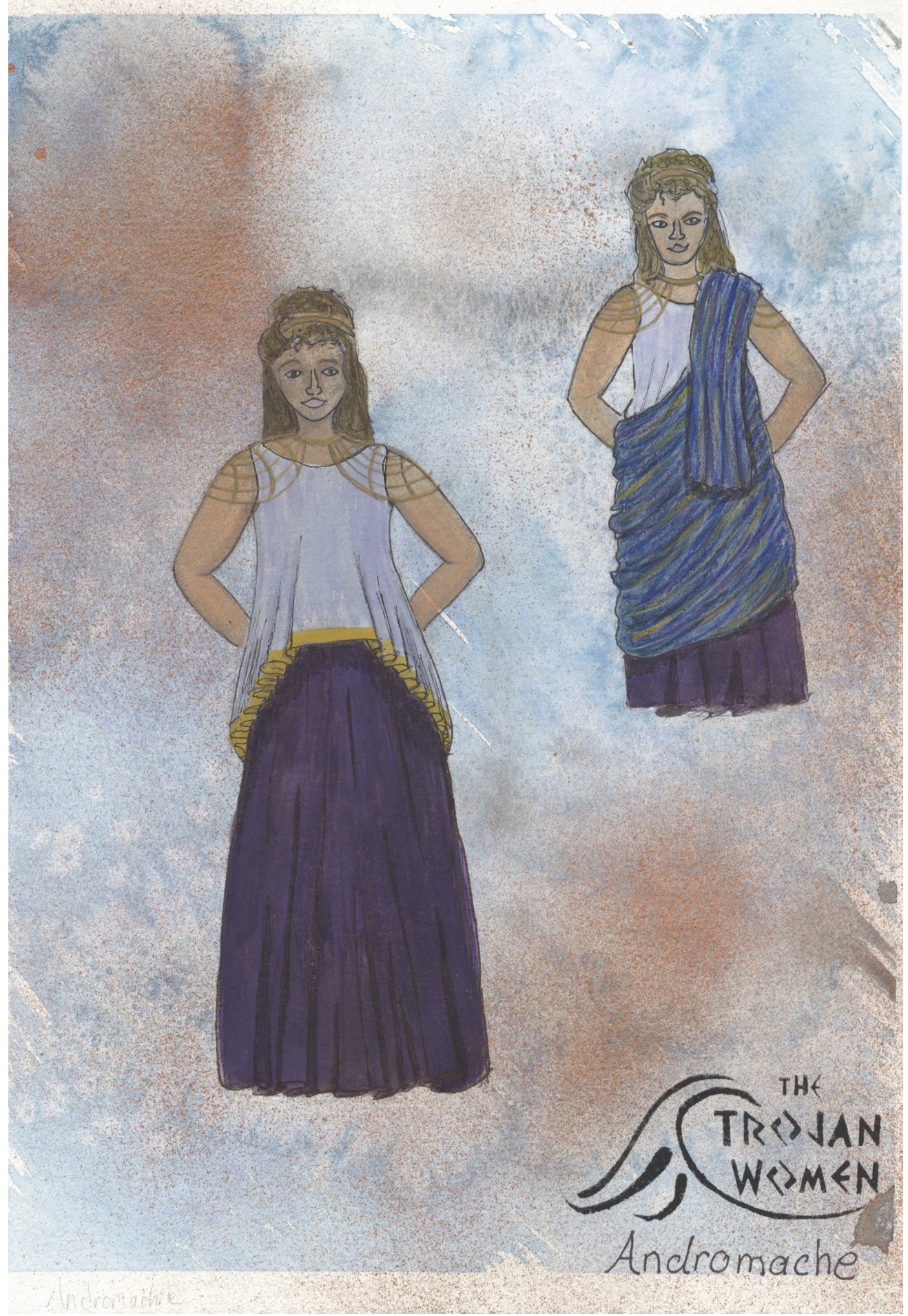

Andromache, final rendering.

Lorich, Cody K. Andromache. 2015. Watercolor \& Marker. West Virginia University School of Theatre \& Dance, Morgantown, WV. Digital Image. 


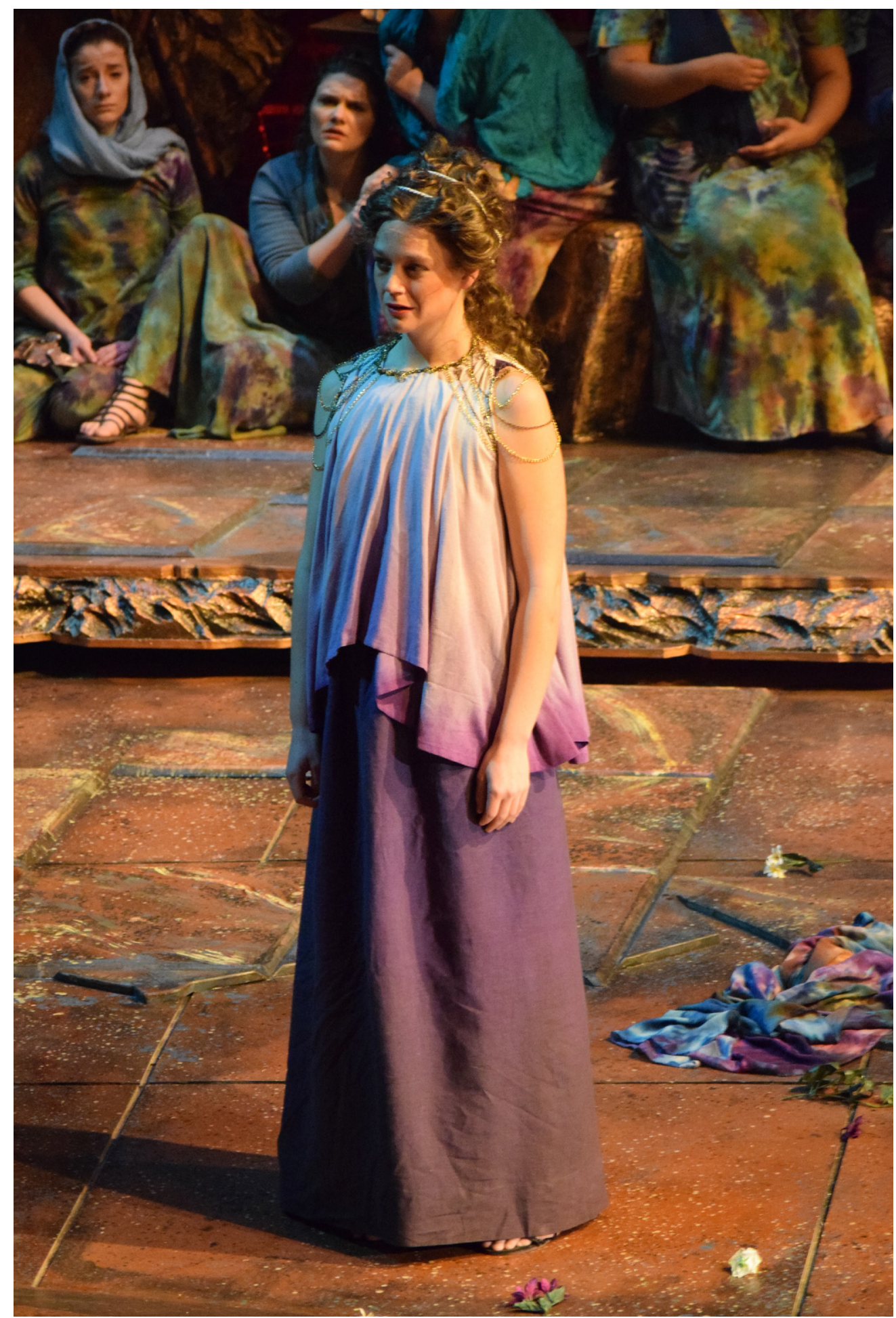

Andromache (Cassandra Hackbart)

Lorich, Cody K. Andromache. 2016. Photograph. West Virginia University School of Theatre \& Dance, Morgantown, WV. 


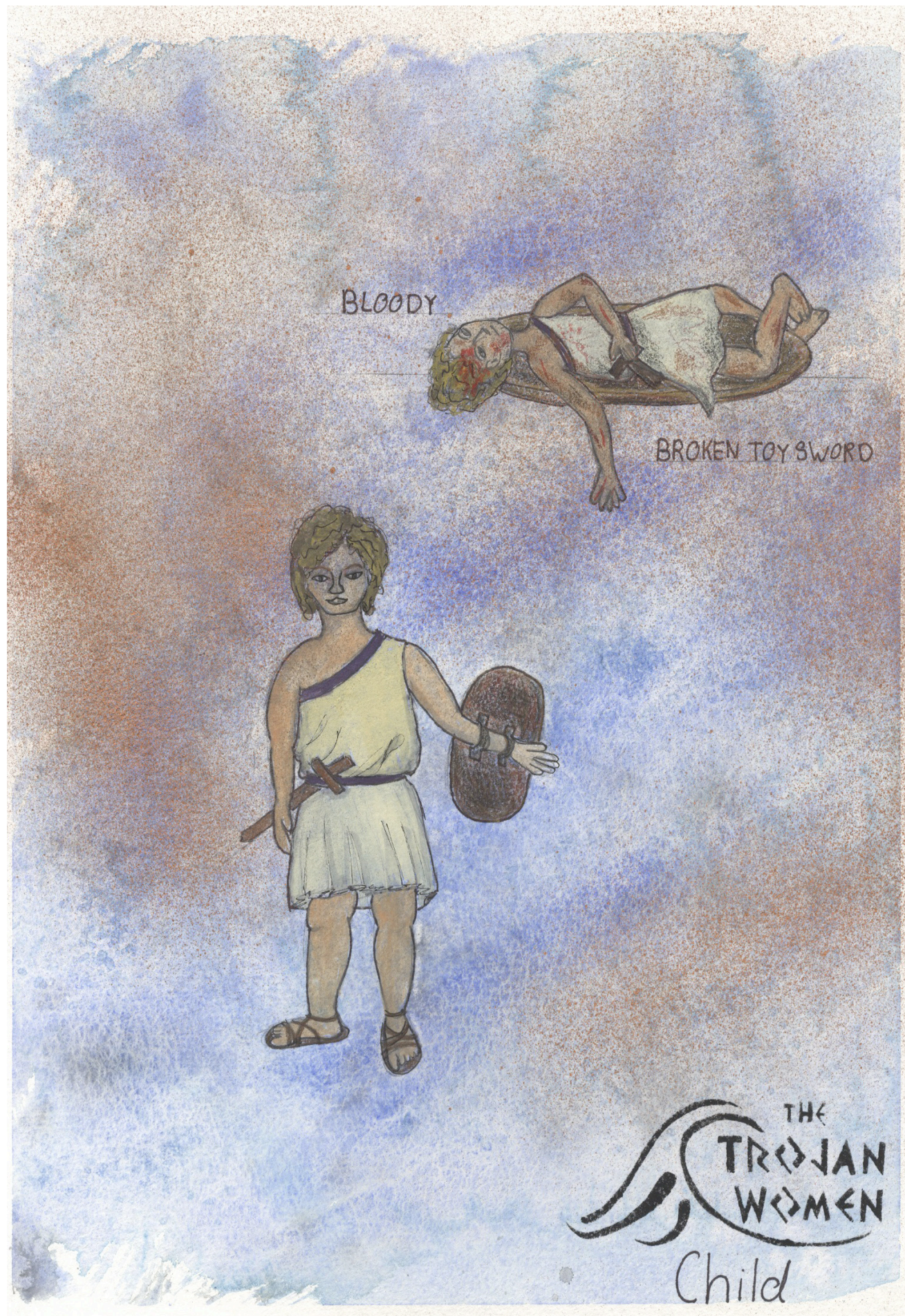

Child, final rendering.

Lorich, Cody K. Child. 2015. Watercolor \& Marker. West Virginia University School of Theatre \& Dance, Morgantown, WV. Digital Image. 


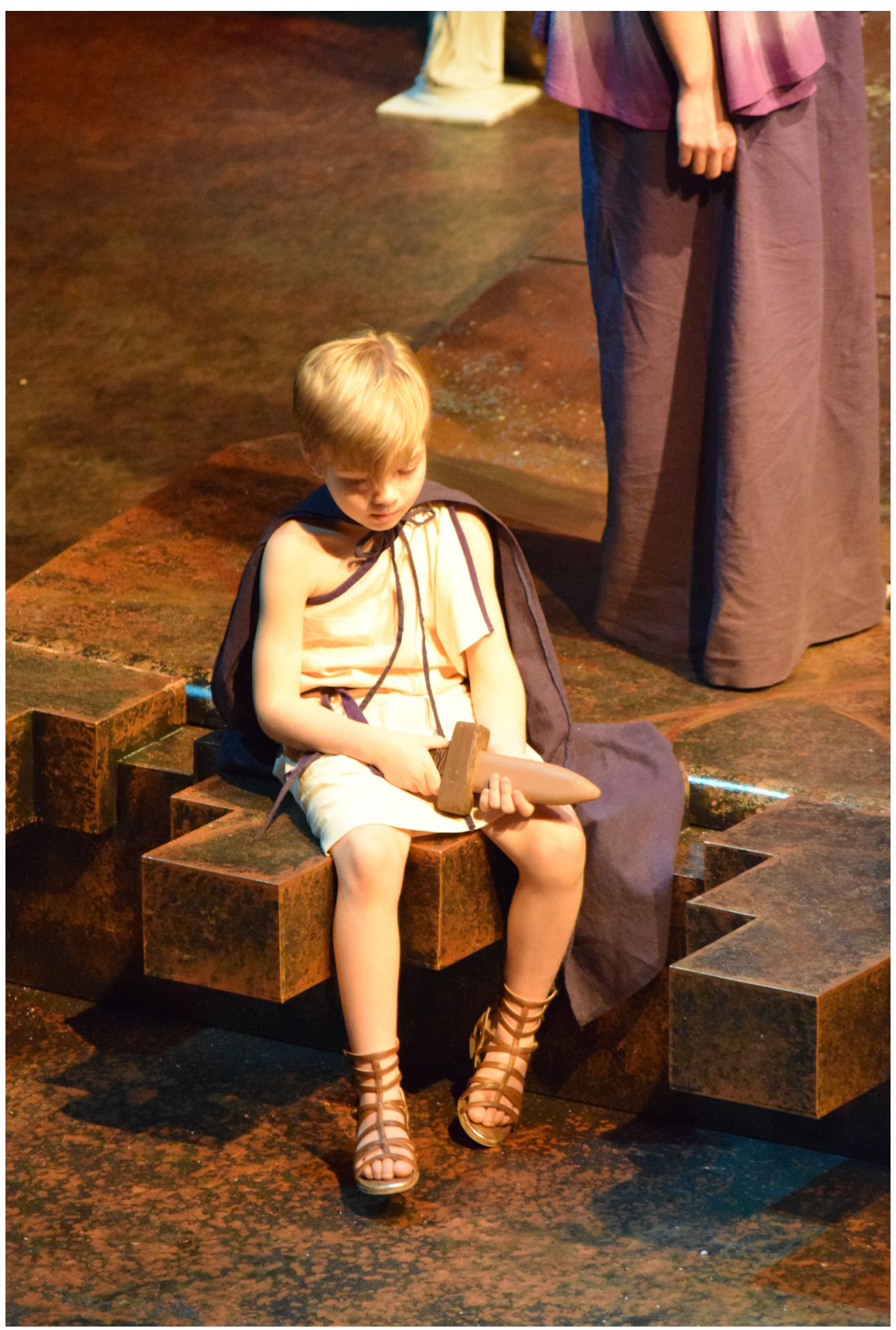

Child (Eben Mugrage)

Lorich, Cody K. Child. 2016. Photograph. West Virginia University School of Theatre \& Dance, Morgantown, WV. 


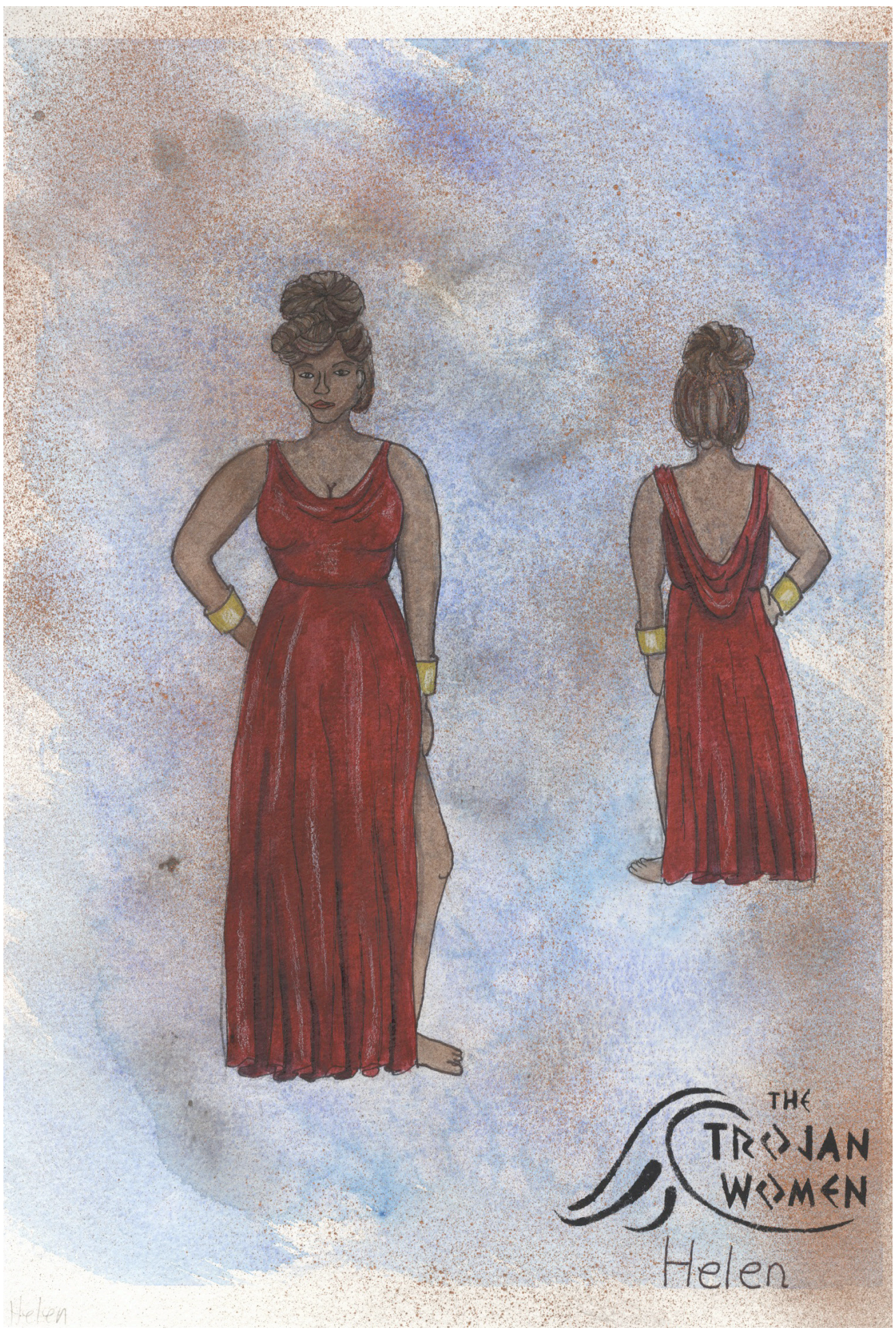

Helen, final rendering.

Lorich, Cody K. Helen. 2015. Watercolor \& Marker. West Virginia University School of Theatre \& Dance, Morgantown, WV. Digital Image. 


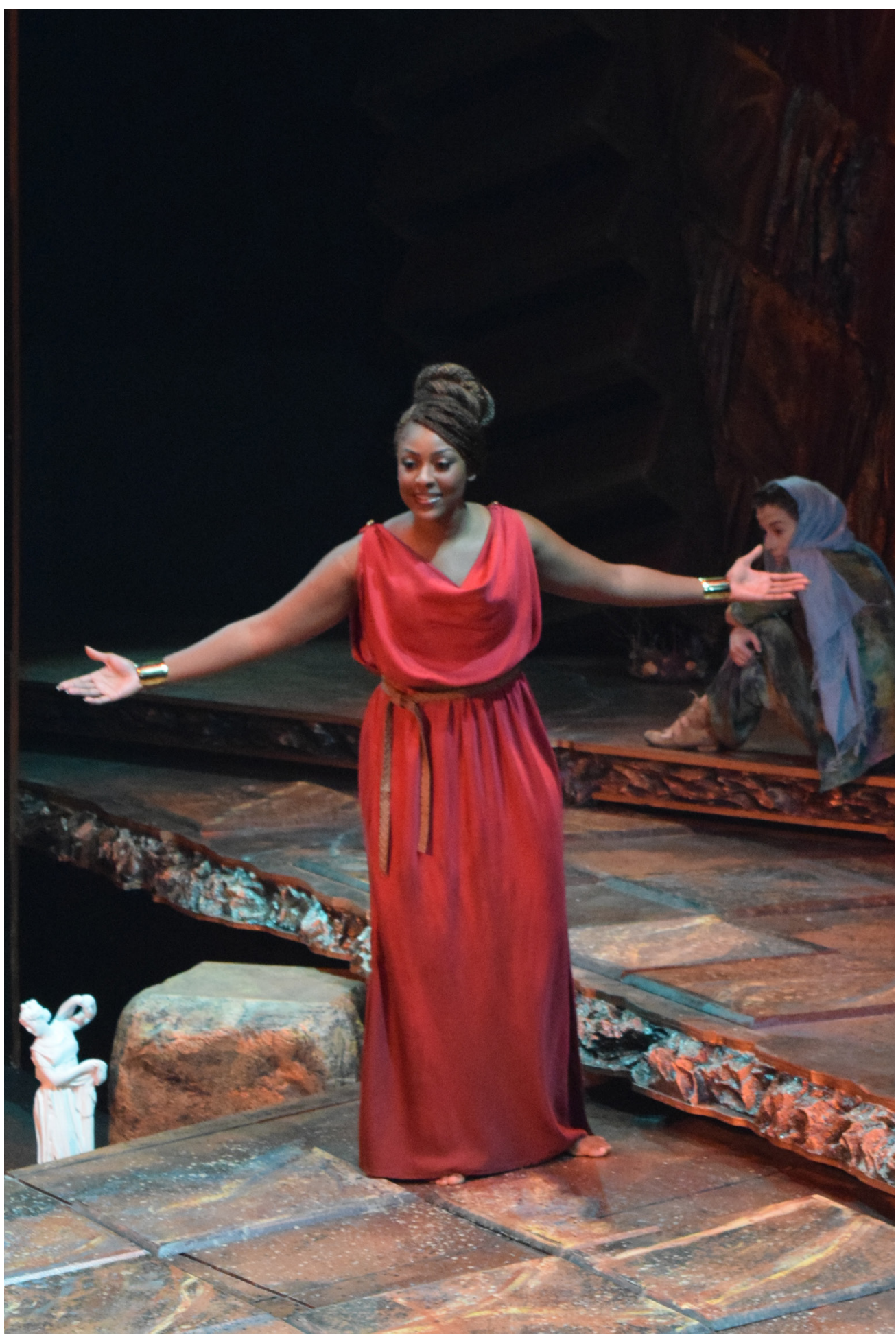

Helen (Christin Wright)

Lorich, Cody K. Helen. 2016. Photograph. West Virginia University School of Theatre \& Dance, Morgantown, WV. 


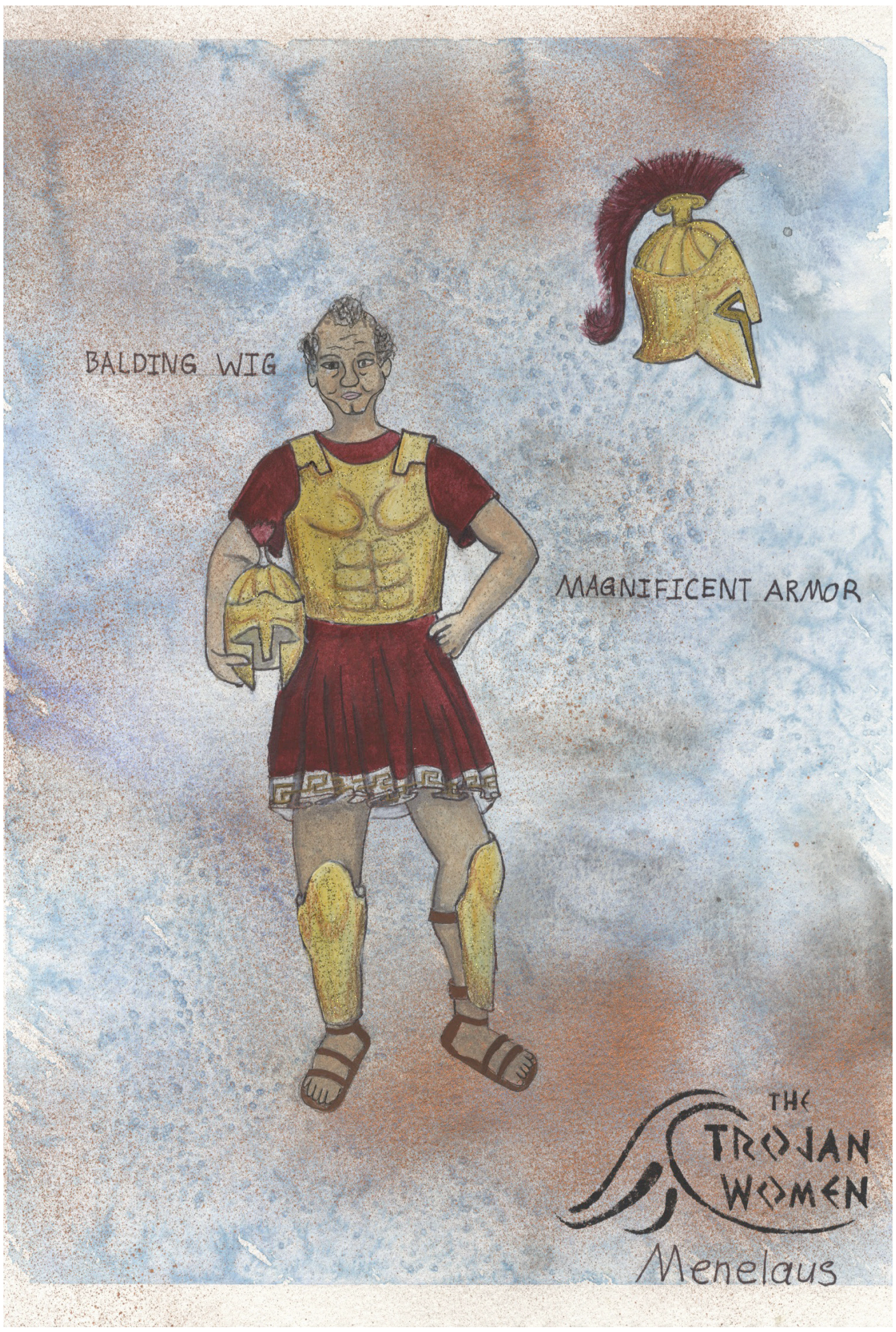

Menelaus, final rendering.

Lorich, Cody K. Menelaus. 2015. Watercolor \& Marker. West Virginia University School of Theatre \& Dance, Morgantown, WV. Digital Image. 


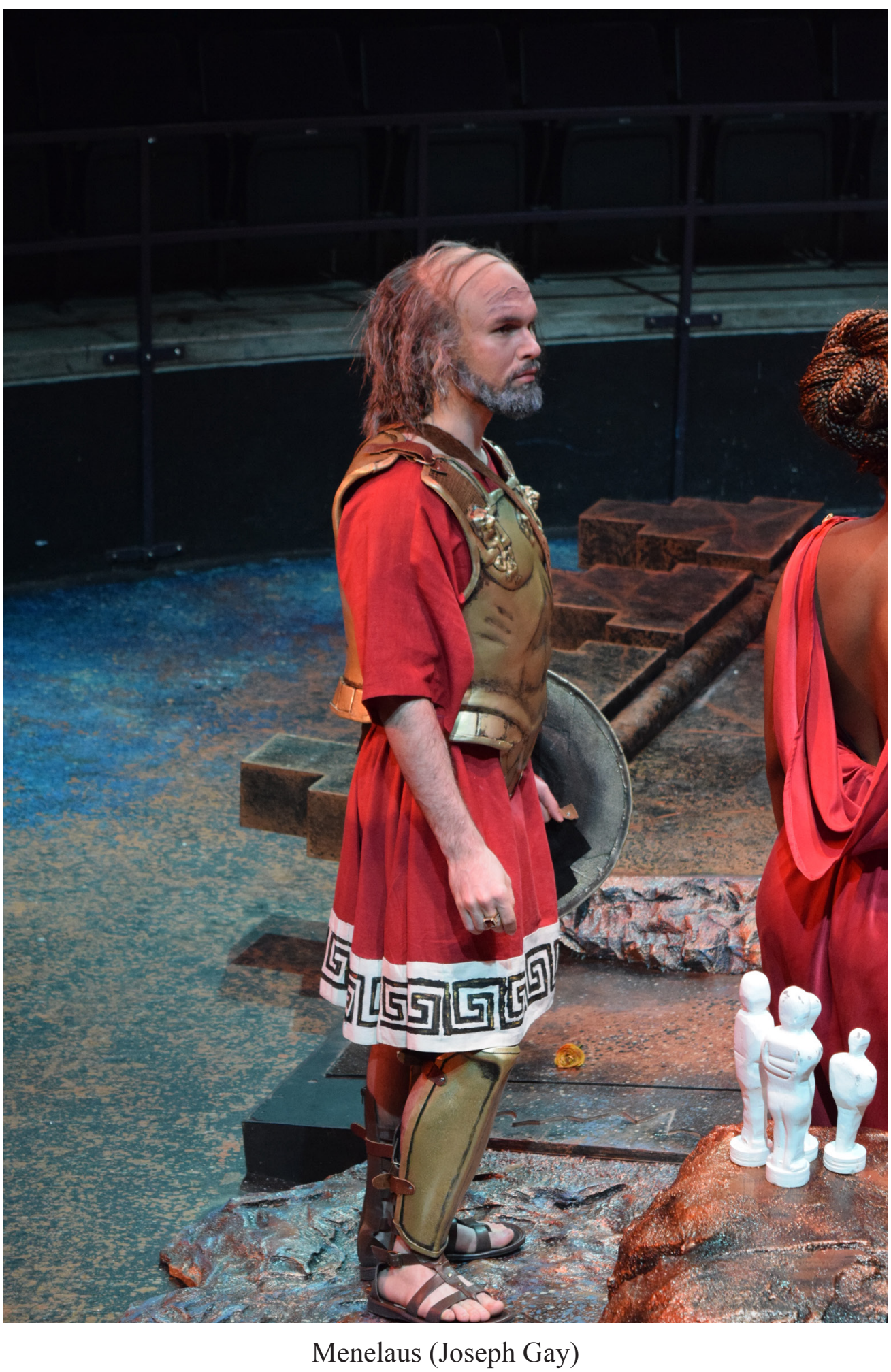

Lorich, Cody K. Menelaus. 2016. Photograph. West Virginia University School of Theatre \& Dance, Morgantown, WV. 


\section{APPENDIX IV: PRODCTION CALANDER}

October

2016

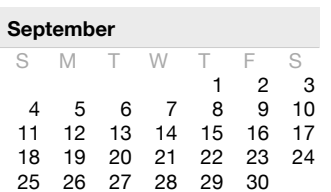

November

$S$ M $T$ W $T$ T $F$ S

$\begin{array}{rrrrrrr}6 & 7 & 8 & 9 & 10 & 11 & 12\end{array}$

$\begin{array}{rrrrrrr}13 & 14 & 15 & 16 & 17 & 18 & 19\end{array}$

$\begin{array}{lllllll}20 & 21 & 22 & 23 & 24 & 25 & 26\end{array}$

$\begin{array}{llll}27 & 28 & 29 & 30\end{array}$

\begin{tabular}{|c|c|c|c|c|c|c|}
\hline SUNDAY & MONDAY & TUESDAY & WEDNESDAY & THURSDAY & FRIDAY & SATURDAY \\
\hline 25 & 26 & 27 & 28 & 29 & 30 & 1 \\
\hline 2 & 3 & 4 & 5 & 6 & 7 & $\varepsilon$ \\
\hline 9 & 10 & 11 & 12 & 13 & 14 & 15 \\
\hline $\begin{array}{l}\text { Noises Off First } \\
\text { Dress }\end{array}$ & & Noises Off Tech & $\begin{array}{l}\text { Noises Off Tech } \\
\text {-Dye Samples of } \\
\text { Chorus and } \\
\text { Principles }\end{array}$ & $\begin{array}{l}\text { Noises Off } \\
\text {-Casting Shells for } \\
\text { Poseidon Crowns }\end{array}$ & $\begin{array}{l}\text { Noises Off } \\
\text { Mock Ups } \\
\text { Complete }\end{array}$ & $\begin{array}{l}\text { Noises Off } \\
\text { Cody- Dye Chorus } \\
\text { sample }\end{array}$ \\
\hline \multicolumn{7}{|c|}{-Chorus Fittings -Mask Work } \\
\hline \multirow[t]{2}{*}{16} & 17 & $\begin{array}{r}7 \\
7\end{array}$ & 3 & 20 & 21 & 22 \\
\hline & $\begin{array}{l}\text {-Dye Principles } \\
\text { Fabrics }\end{array}$ & $\begin{array}{l}\text {-Chorus } \\
\text { Alterations done } \\
\text {-Dye Principles } \\
\text { Fabrics }\end{array}$ & $\begin{array}{l}\text { Publicity Photos } \\
\text {-Start cutting } \\
\text { Fashion Fabrics } \\
\text {-Build Bases for } \\
\text { Crowns }\end{array}$ & $\begin{array}{l}\text {-First Fittings } \\
\text { Done } \\
\text {-Dye Chorus } \\
\text { Round one }\end{array}$ & $\begin{array}{l}\text {-Prep Shoulder } \\
\text { Jewelry } \\
\text {-Prep Soldiers } \\
\text { vests } \\
\text {-Dye builds }\end{array}$ & $\begin{array}{l}\text { 10:30 Trial Bald } \\
\text { Cap Day }\end{array}$ \\
\hline \multicolumn{7}{|c|}{-Mask work -Ventilating -Soldiers Helmets \& Greaves } \\
\hline \multirow{3}{*}{23} & 24 & 25 & 26 & 27 & 28 & 28 \\
\hline & $\begin{array}{l}\text {-Dye Chorus } \\
\text { Round Two }\end{array}$ & $\begin{array}{l}\text {-Dye Chorus } \\
\text { Round Three } \\
\text {-Mask } \\
\text { construction done }\end{array}$ & $\begin{array}{l}\text {-Start painting } \\
\text { Masks } \\
\text {-Dye builds }\end{array}$ & -Dye builds & $\begin{array}{l}\text {-Soldiers Helmets } \\
\text { \& Greaves Done } \\
\text {-Chorus dying } \\
\text { done } \\
\text {-Shoulder Jewelry } \\
\text { done }\end{array}$ & \\
\hline & & & \multicolumn{3}{|c|}{-Construct/ Paint Crowns } & \\
\hline \multicolumn{7}{|c|}{-Fittings and Alterations -Fit \& paint Menelaus' Armor -Ventilating -Soldiers Vests } \\
\hline 30 & 31 & & & & & \\
\hline
\end{tabular}


November

2016

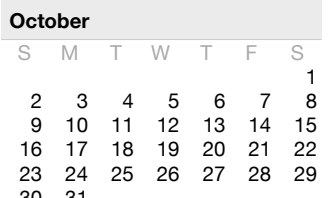

December

S M T W T F S

$\begin{array}{rrrrrrr}4 & 5 & 6 & 7 & 8 & 9 & 10\end{array}$

$\begin{array}{rrrrrrr}11 & 12 & 13 & 14 & 15 & 16 & 17\end{array}$

$\begin{array}{lllllll}18 & 19 & 20 & 21 & 22 & 23 & 24\end{array}$

$\begin{array}{lllllll}25 & 26 & 27 & 28 & 29 & 30 & 31\end{array}$

$\begin{array}{ll}30 & 31\end{array}$

\begin{tabular}{|c|c|c|c|c|c|c|}
\hline SUNDAY & MONDAY & TUESDAY & WEDNESDAY & THURSDAY & FRIDAY & SATURDAY \\
\hline & & 1 & 2 & 3 & 4 & 5 \\
\hline & & & $\begin{array}{l}\text {-Ventilating Done } \\
\text {-Masks Done } \\
\text {-Dye Builds Done }\end{array}$ & -Start Wig Styling & $\begin{array}{l}\text {-Crowns Done } \\
\text {-M Armor Done } \\
\text {-Soldiers Vests Done }\end{array}$ & \\
\hline \multicolumn{7}{|c|}{-Final Fittings -Paint Masks - Fit \& paint Menelaus' Armor -Soldiers Vests -Construct/ Paint Crowns } \\
\hline 6 & 7 & 8 & 9 & 10 & 11 & 12 \\
\hline & $\begin{array}{l}\text { Costume Plot and } \\
\text { Laundry List due }\end{array}$ & & $\begin{array}{l}\text {-Final Alterations } \\
\text { Done }\end{array}$ & Crew View & Rack Costumes & $\begin{array}{l}\text { Wig and Makeup } \\
\text { Training }\end{array}$ \\
\hline \multicolumn{7}{|c|}{-Wig Styling -Crafts Final Touches } \\
\hline 13 & 14 & 15 & 16 & 17 & 18 & 19 \\
\hline First Dress & Dark & Second Dress & $\begin{array}{l}\text { Final Dress/ } \\
\text { Preview }\end{array}$ & Opening & Performance & Thanksgiving Break \\
\hline 20 & 21 & 22 & 23 & 24 & 25 & 26 \\
\hline Thanksgiving Break & Thanksgiving Break & Thanksgiving Break & Thanksgiving Break & Thanksgiving Break & Thanksgiving Break & Thanksgiving Break \\
\hline 27 & 28 & 29 & 30 & 1 & 2 & 3 \\
\hline Thanksgiving Break & & Performance & Performance & Performance & Performance & Performance \\
\hline 4 & 5 & 6 & 7 & 8 & 9 & 10 \\
\hline Strike & & & & & & \\
\hline
\end{tabular}




\section{APPENDIX V: PRODCTION SPENDING}

Trojan Women Budget Spending

\begin{tabular}{|c|c|c|c|c|c|}
\hline Purpose & Vender & Amount & Cardholder & Receipt Number & \\
\hline Laundry Supplies & Walmart & 18.44 & Sharon & 1 & \\
\hline Tape for Wigs & Walmart & 0.97 & & 2 & \\
\hline Wig Lace & His \& Her Hair & 140.00 & Mary & 3 & \\
\hline Mask Supplies & AC Moore & 48.81 & & 4 & \\
\hline Mask Supplies & Walmart & 11.56 & & 5 & \\
\hline Fabric and Chorus Clothes & Dharma & 294.76 & & 6 & \\
\hline Zach Spartan Sandals & Amazon & 49.27 & & 7 & \\
\hline Fabrics & Dharma & 393.69 & & 8 & \\
\hline Squeeze Bottle & Amazon & 17.98 & & 9 & \\
\hline Poseidon Wigs & Ebay & 69.77 & & 10 & \\
\hline Elise Bra & Gabes & 6.99 & & 11 & \\
\hline Cassandra Fabric & PureSilks & 84.00 & & 12 & \\
\hline Briana G Dress & Zappos & 73.14 & & 13 & \\
\hline Linen shirts & Amazon & 35.98 & & 14 & \\
\hline Tank & Amazon & 6.21 & & 15 & \\
\hline Boys Pants & JcPennys & 143.06 & & 16 & \\
\hline Fabric Dyes & Dharma & 154.72 & & 17 & \\
\hline Chorus Sweaters & Good Will & 18.67 & & 18 & \\
\hline Bald cap supplies & Burman & 85.36 & $\begin{array}{l}\text { UPS Tracking\# } \\
1 \text { z5y893103609439 } \\
93\end{array}$ & 19 & \\
\hline Wig supplies & Wig America & 66.69 & Mary & 20 & \\
\hline Chorus Tops & Gabes & 44.98 & & 21 & \\
\hline Riot Helmets \& Face Shields & Amazon & 135.08 & & 22 & \\
\hline Elise Dress & Amazon & 29.95 & & 23 & \\
\hline Tactical vest & Ebay & 182.72 & & 24 & \\
\hline Fabric and Dye & Hobby Lobby & 31.94 & :auren & 25 & \\
\hline Zach Spartan Sandals NEW! & Amazon & 49.27 & & 26 & \\
\hline Christin Bra & Amazon & 46.64 & & 27 & RETURNED \\
\hline craft supplies & Lowes & 60.78 & & 28 & \\
\hline mask Felt & Michaels & 1.87 & & 29 & \\
\hline Chorus Shoes & Gabes & 30.96 & & 30 & \\
\hline Chains and Crown things & AC Moore & 10.69 & & 31 & \\
\hline Shoes & Rue 21 & 12.00 & & 32 & \\
\hline Bra elastic & Amazon & 6.63 & & 33 & \\
\hline Shop Muslin Fabric & & 87.61 & Sharon & 34 & \\
\hline Low back body shaper & Amazon & 21.95 & & 35 & \\
\hline Solider Sandals & Judaica Web Store & 138.79 & & 36 & \\
\hline Stiff stuff & Amazon & 22 & & 37 & \\
\hline
\end{tabular}




\begin{tabular}{|c|c|c|c|c|c|}
\hline Purpose & Vender & Amount & Cardholder & Receipt Number & \\
\hline Christin Bra & Amazon & -46.64 & & 38 & REFUND!!! \\
\hline Craft and Wig Supplies & Walmart & 38.12 & & 39 & \\
\hline Fabric and Crafts & Hobby Lobby & 48.82 & & 40 & \\
\hline Fabric and Crafts & Hobby Lobby & 49.43 & & 41 & \\
\hline Soda Ash & Dharma & 60.89 & & 42 & \\
\hline Chorus Shoes & Rue 21 & 22.99 & & 43 & \\
\hline Sunglasses Masks & Walmart & 53.87 & & 44 & \\
\hline Foam and Feathers & AC Moore & 17.76 & & 45 & \\
\hline Colored Hair Spray & Spirt Halloween & 19.95 & & 46 & \\
\hline Colored Hair Spray & Walmart & 19.52 & & 47 & \\
\hline Canvas for soldiers & Hobby Lobby & 48.71 & & 48 & \\
\hline Colored Hair Spray & Everyday a Party & 40.94 & & 49 & \\
\hline Paper Towels & Walmart & 28.94 & Sharon & 50 & \\
\hline Fabric sample & Fabric on a Roll & 3.50 & Mary & 51 & \\
\hline Canvas for soldiers & Hobby Lobby & 46.20 & Sharon & 52 & \\
\hline Menelaus Armor & Tobins Lake & 93.87 & & 53 & \\
\hline White Acrlyic Paint & Michaels & 12.97 & & 54 & \\
\hline Lots of wood glue & Lowes & 46.94 & & 55 & \\
\hline Contact cement & Lowes & -12.98 & & 56 & REFUND!!! \\
\hline Glasses Hooks & Amazon & 10.98 & & 57 & \\
\hline Liquid latex & Burman & 98 & & 58 & \\
\hline Eben Shoes & Amazon & 61.81 & & 59 & \\
\hline Gold Cuffs & Amazon & 25.98 & & 60 & \\
\hline Rivets & Ace hardware & 9.87 & & 61 & \\
\hline more hair spray & Everyday a Party & 5.18 & & 62 & \\
\hline Gold Paint & Walmart & 24.20 & & 63 & \\
\hline Shoe repair & Tanners Alley & 42.00 & & 64 & \\
\hline Makeup supplies & CVS & 22.18 & & 65 & \\
\hline Makeup supplies & Illusive Skull & 75 & & 66 & \\
\hline sewing supplies & Hobby Lobby & 49.34 & Sharon & 67 & \\
\hline Sandpaper & Walmart & 10.99 & Sharon & 68 & \\
\hline \multirow[t]{2}{*}{ Bobby Pins } & Sallys Beauty & 7.29 & Sharon & 69 & \\
\hline & Total Spending & 3420.39 & Total Refunds & 59.62 & \\
\hline
\end{tabular}


APPENDIX VI: INITIAL BUDGET AND PIECE LIST

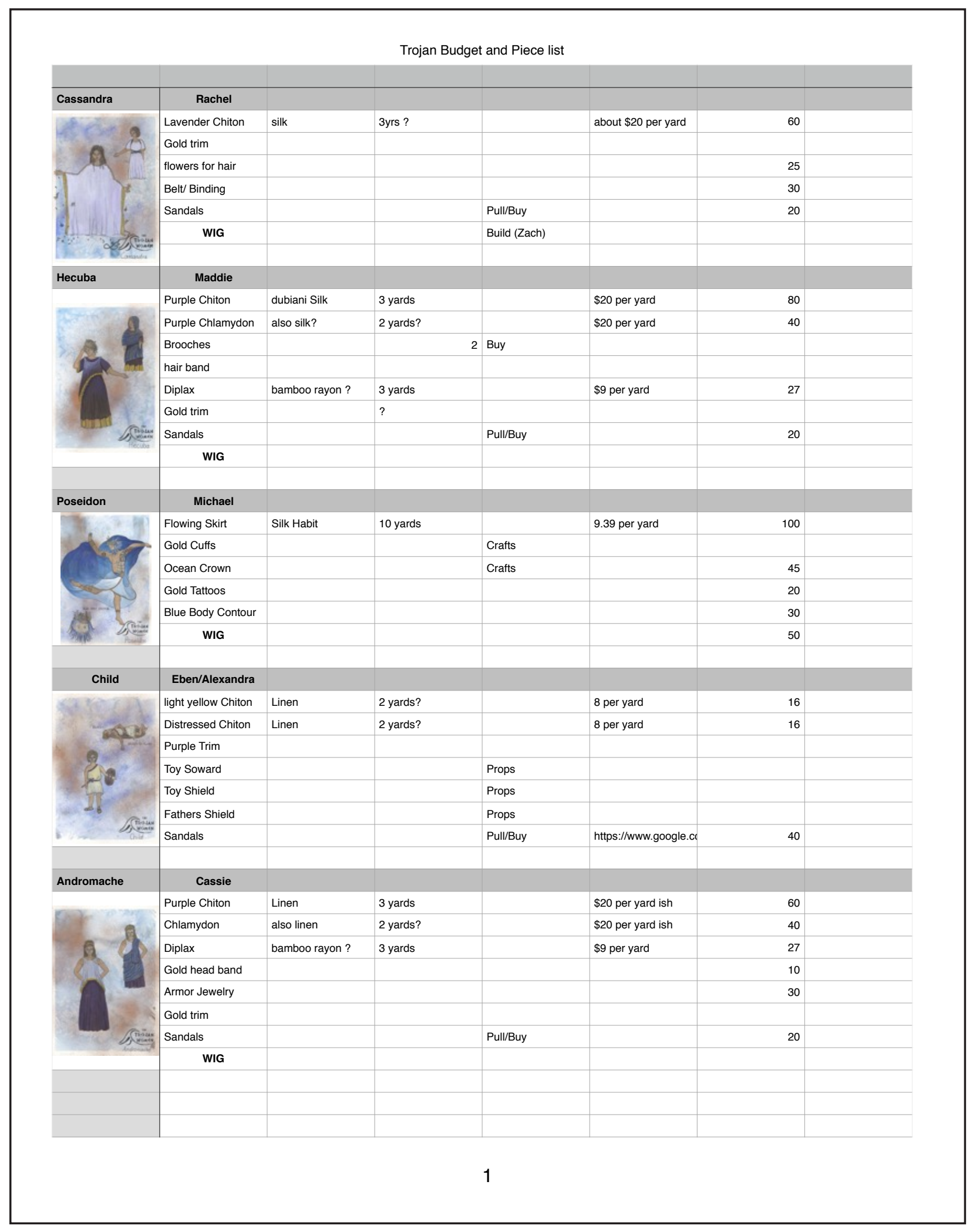




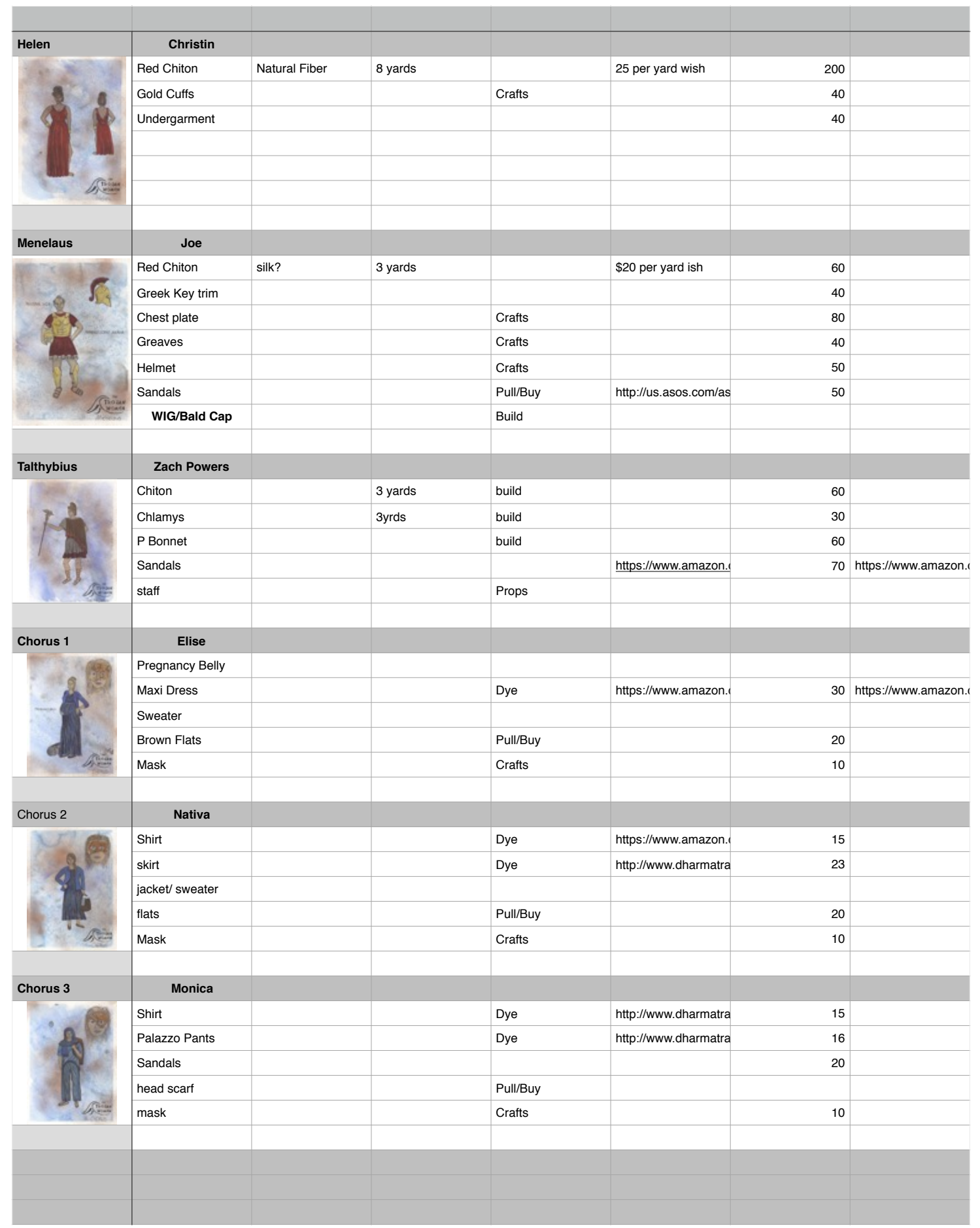




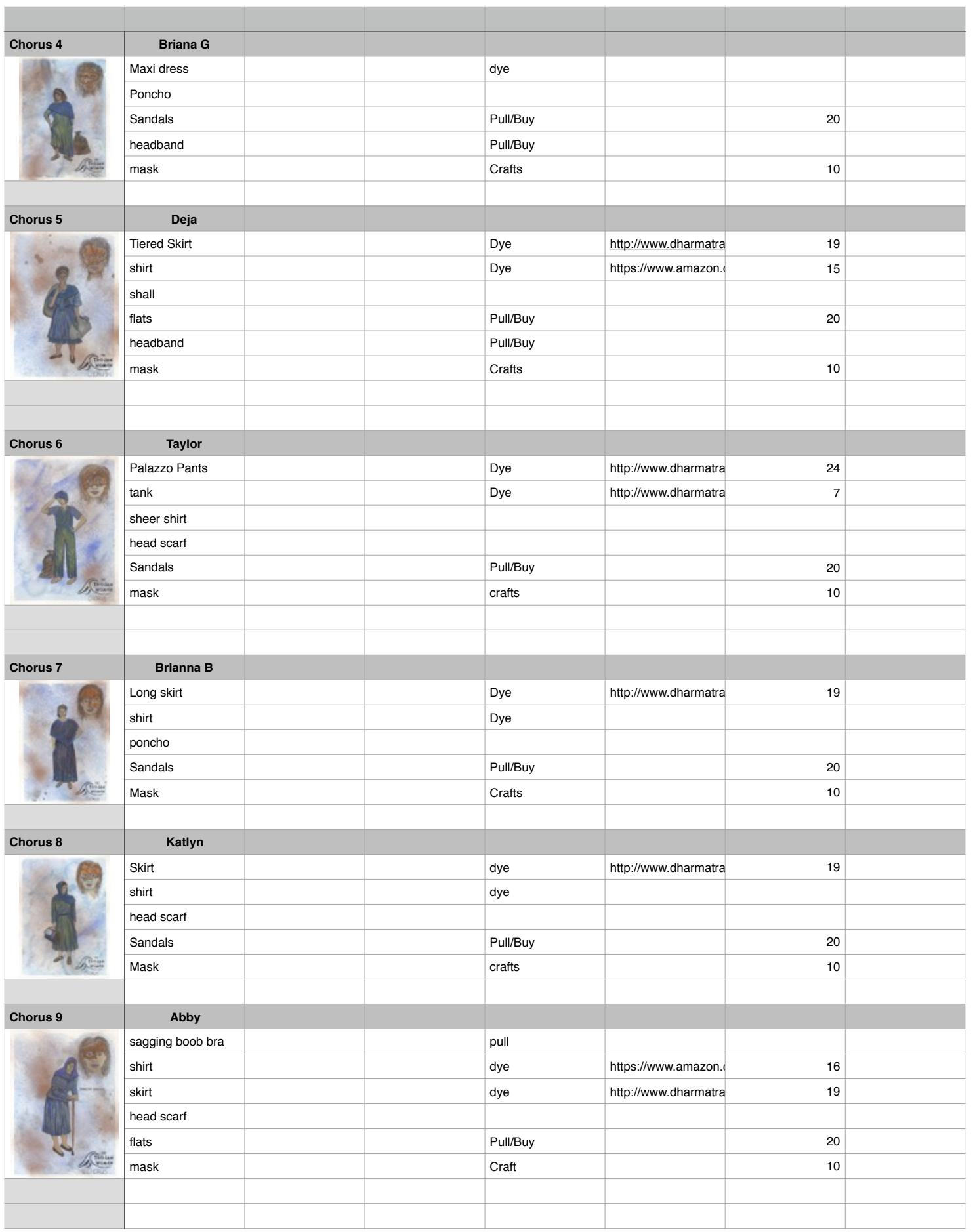




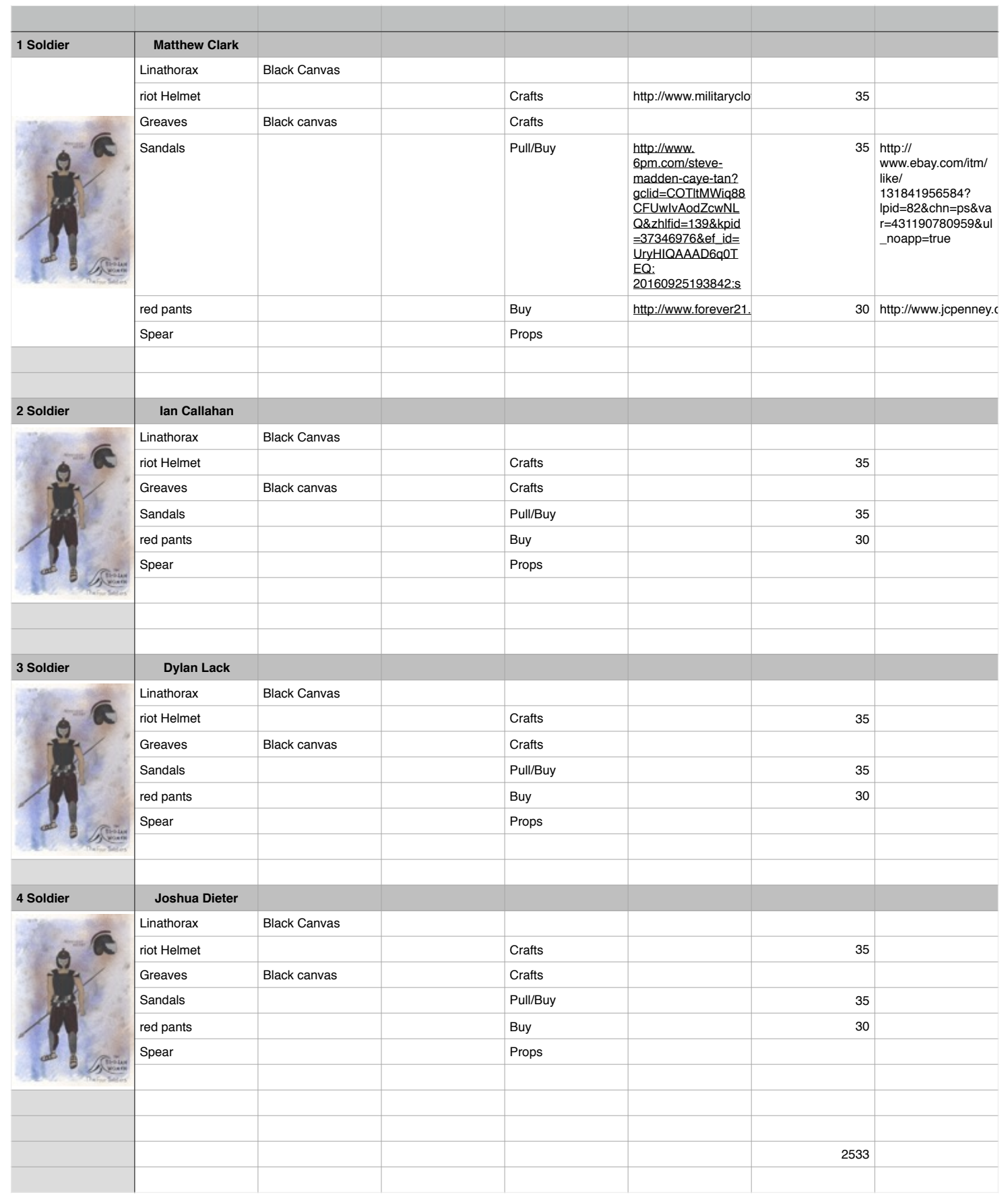




\section{APPENDIX VII: SAMPLE OF DAILY REPORT}

Costume Report: The Trojan Women

November 3, 2016

\section{To Do List:}

- Katy

\section{○ Soldiers}

- Greaves

- Add elastic straps

- Attach with grommets

- Paint/cover back

- Vests

- Pattern shoulder cap

- Peplum tabs

○ Attach to vests

- Lauren

- Soldiers

- Helmets

○ Masks

- Reattach visors (next week)

- Attach glasses

○ In process

- Make Velcro headbands for other 3 masks

○ Wigs

- Michael

- Other

$\circ$ Finish ventilating mustache

- Trim wig

- Stitch Beard elastic

Michael Crown

- Styling

- Glue all the doodads to base (Friday)

- Laura

- Prep chorus tags that need to be relabeled

- Flowers for Cassandra's wig need paint touches to make them appear less like fake flowers (Just a few left)

- Cody

Pour dye technique for Andromache

- Dye other piece of fabric for Michael 
Costume Report: The Trojan Women

November 3, 2016

- Zach

○ Cloak-

- Prepped and ready for finishing

- Cody Pull brooch or something to add as a fake closure to his

- Joe G cape

- Chiton

- Armor

- Paint trim (final week)

- Maybe attach Stomacher piece (not sure because he is bending a lot)

- Fossharp pieces on helmet and shoulders

- Cover edges

- Prime

- Paint

- Needs a place to keep his sward on him!

- Christin Dress

- Final Hem after first dress

- Cassie

- Attach Jewelry to costume

- Maddie

- Sleeve Hem

o Hem

- Snaps on shoulders to over top

- Over top

- Hem

- Stitch other arm (one is done)

- Eben

- Add Trim

- Cloak

- Attach ties

- Elise

- Pep up pregnancy belly

- The rehearsal skirt is pushing it down

- Rachel

- Fix mock up

- Shoes!!!!!

- It is hanging too long and she is tripping

- Make them all look worn and aged 
Costume Report: The Trojan Women

November 3, 2016

\section{Note:}

- Laura and Katy will be in and out for Dance meetings.

- After watching this evenings run I am concerned about the glasses method for the masks

- Rachel is going to need a LOT of wig pins in her hair, she is flinging around all over the place

\section{Shopping List:}

- Pull: Black Tanks for soldiers

- Taking Cassie, Maddie and Rachel's shoes to tanners ally

\section{Fitting Request:}

\section{Goals for Tomorrow 11/5:}




\section{WORKS CITED}

Doerries, Bryan. Theater of War: What Ancient Tragedies Can Teach Us Today. New York: Vintage, 2016. Print.

Fashion: The Definitive History of Costume and Style. London U.a.: DK, 2012. Print.

MacEwen, Gwendolyn. The Trojan Women. Toronto: Playwrights Co-op, 1979. Print.

Reed, Christopher. "Dazzlers." Harvard Magazine. Harvard Magazine Inc., 21 Dec. 2007. Web.

Wright, Jeff. "Trojan War: The Podcast." Audio blog post. Trojan War: The Podcast. WordPress, 26 Feb. 2016. 


\section{IMAGE SOURCES}

1. West Virginia University Photography. Cast Tablue, 2017. Photograph. West Virginia University of Theatre \& Dance, Morgantown, WV. Digital Image.

2. Gigantomachy, Delphi Archaeological Museum. Mes Beaus-Art, 530 BC. Marble. mesbeauxarts.tumblr.com.

3. Caryatid from Porch of the Maidens, British Museum. Greece Ancient and Modern. 421-05 BC. Pentelic Marble. greeceancientmodern.com.

4. Woodford, Susan. Ajax and Achilles playing a game. 1998. The Trojan War in Ancient Art. Ithaca, New York: Cornell University Press. 60. Print.

5. Menelaus Supporting the Body of Patroclus. Loggia dei Lanzi, Timur Kulgrin.

Photographer. Encyclopaedia Bertannica, University of Oxford, $17^{\text {th }}$ century. britannica. com.

6. Menelaos vase, Museume of Art, Toledo (OH), Classical Art Research Centre, University of Oxford, mid $5^{\text {th }}$ century. beazley.ox.ac.uk.

7. De Morgan, Evelyn. Helen of Troy, Fine Art America. 1898. Oil On Canvas. fineartamerica.com.

8. Phillipkay, Helen of Troy. BestQuest. 22 Sept. 2009. Digital Art. phillipkay.wordpress. com.

9. Poseidon Riding a Whale, Digital Art. Greek Mythology Pantheon. 2013. greek-mythology-pantheon.com.

10. Grave Stele of Paramythion. Ancients reborn in bright array. Christopher Reed, 2007. Harvard Magazine. harvardmagazine.com.

11. Man in Chiton. 24 February 2016. Photograph. Costume-History Ancient Greece. historyoffashiondesign.com.

12. Hemingway, Colette. Marble funerary statues of a maiden and a little girl. Women in Classical Greece. 320 B.C. Stone Sculpture. The Met Museum. metmuseum.org. 
13. Richter, Gisela M.A. Youth wearing a chlamys from a Greek case. 1929. Sculpture \& Sculptors of the Greeks. New Haven: Yale University Press. Print.

14. Statue of Zeus, Staatliche Kunstsammlungen, Classical Art Research Centre, University of Oxford, cvaonline.org.

15. Sarvis, David. Warrior in Bronze Armor. 1963. Historic Costume for the Stage. Boston: Walter H Baker, n.d. 57. Print.

16. Kleophrades Painter, The Sack of Troy. 490-480 B.C., The Trojan War in Ancient Art. Museo Nazionale Archaeological Museum, 490-480 B.C., attic red figure hydria. 1998. 116. Print.

17. Lorich, Cody. Poseidon. 2016. Watercolor \& Marker. West Virginia University School of Theatre \& Dance, Morgantown, WV. Digital Image.

18. West Virginia University Photography. Poseidon, 2017. Photograph. West Virginia University of Theatre \& Dance, Morgantown, WV. Digital Image.

19. Rodolfoguerreiro. Poseidon under a Cloudy Sky, Digital Art. Greek Mythology Pantheon. 2013. greek-mythology-pantheon.com.

20. Blue Teal Dreads. Hair Color Ideas, 18 July 2014. haircolorsideas.com.

21. Chelsea Shiels (chelseasflowercrowns). Mermaid Crown. Instagram, 15 June 2016. Photograph.

22. Lorich, Cody. Chorus Women. 2016. Watercolor \& Marker. West Virginia University School of Theatre \& Dance, Morgantown, WV. Digital Image.

23. West Virginia University Photography. Greek Chorus, 2016. Photograph. West Virginia University of Theatre \& Dance, Morgantown, WV. Digital Image.

24. WWII Belgian Refugees. Children in History, La Gleize, Belgian, 12 Aug. 2014. histclo. com.

25. Cassie, Webber. Syrian Children Who Fled from ISIS, Chiangrai Times, 2 April 2016. chiangraitimes.com. 
26. Lorich, Cody. Pottery Mask. 2016. Watercolor \& Marker. West Virginia University School of Theatre \& Dance, Morgantown, WV. Digital Image.

27. Mitoraj, Igor. Tindaro Screpolato. Boboli Garden, Florence, Italy. My Modern Met. 1998. mymodernmet.com.

28. Lorich, Cody. Statue Mask. 2016. Watercolor \& Marker. West Virginia University School of Theatre \& Dance, Morgantown, WV. Digital Image.

29. Pike, David. An Example of Kintsugi Repair. Studio KotoKoto, San Diego, California, 12 Dec. 2014, studiokotokoto.com.

30. Lorich, Cody. Soldiers. 2016. Watercolor \& Marker. West Virginia University School of Theatre \& Dance, Morgantown, WV. Digital Image.

31. Lorich, Cody. Soldier, 2017. Photograph. West Virginia University of Theatre \& Dance, Morgantown, WV. Digital Image.

32. Achilles Painter name vase, Vatican Museum, M. Tiverios, Photographer, Classical Art Research Centre, University of Oxford, mid $5^{\text {th }}$ century. www.beazley.ox.ac.uk.

33. Concealed Body Armor Level IIIA, Tatical Scorpion Gear. 2015. tacticalscorpiongear. com.

34. Polycarbonate Alloy Riot Helmet, Sirchie. 2016. sirchie.com.

35. Athenian Helmet (recreation), Hellenic-Art. 2016. hellenic-art.com.

36. Lorich, Cody. Hecuba. 2016. Watercolor \& Marker. West Virginia University School of Theatre \& Dance, Morgantown, WV. Digital Image.

37. Lorich, Cody. Hecuba, 2016. Photograph. West Virginia University of Theatre \& Dance, Morgantown, WV. Digital Image.

38. CyberGod, Beauty of Wilting Flower, Cyber Phoenix. 15 Oct. 2011. cyberphoenix.org.

39. Greek Lady from Sicily. Munich picture sheets, Fashion of the Centuries, Braun and Schneider. 1858-1898. world4.eu.

40. Sarvis, David. Draped Himation. 1963. Historic Costume for the Stage. Boston: Walter H Baker, n.d. 63. Print. 
41. Lorich, Cody. Cassandra. 2016. Watercolor \& Marker. West Virginia University School of Theatre \& Dance, Morgantown, WV. Digital Image.

42. Lorich, Cody. Cassandra, 2016. Photograph. West Virginia University of Theatre \& Dance, Morgantown, WV. Digital Image.

43. Lester, Katherine and Kerr, Rose Netzorg. Bound Ionic chiton. 1967. Make it a Tunic! KET distant learning, dl.ket.org.

44. Lester, Katherine and Kerr, Rose Netzorg. Ionic chiton. 1967. Make it a Tunic! KET distant learning, dl.ket.org.

45. Burckhardt, Marc. Cassandra, Acrylic and Oil on Wood Panel. Marc Burckhardt Art. marcburckhardt.com.

46. Lorich, Cody. Talthybius. 2016. Watercolor \& Marker. West Virginia University School of Theatre \& Dance, Morgantown, WV. Digital Image.

47. Lorich, Cody. Talthybius, 2016. Photograph. West Virginia University of Theatre \& Dance, Morgantown, WV. Digital Image.

48. Hermes. Greek gods and goddesses. n.d. Attic cup pottery.

49. Youth wearing a Phrygian cap, Fitzwilliam Museum, Encyclopedia Britannica, $4^{\text {th }}$ century. britannica.com.

50. Lorich, Cody. Andromache. 2016. Watercolor \& Marker. West Virginia University School of Theatre \& Dance, Morgantown, WV. Digital Image.

51. Lorich, Cody. Andromache, 2016. Photograph. West Virginia University of Theatre \& Dance, Morgantown, WV. Digital Image.

52. Girl in Chiton. Munich picture sheets, Fashion of the Centuries, Braun and Schneider. 1858-1898. world4.eu.

53. Weagain, Punk Multi-layered Shoulder Jewelry. Digital image. Ebay. n.p.,n.d. ebay.com.

54. Lorich, Cody. Child. 2016. Watercolor \& Marker. West Virginia University School of Theatre \& Dance, Morgantown, WV. Digital Image. 
55. Lorich, Cody. Child, 2016. Photograph. West Virginia University of Theatre \& Dance, Morgantown, WV. Digital Image.

56. Boy in Chiton, History of Fashion: Greece. The Bertho Times. 27 Aug. 2015. theberthotimes.blogspot.com.

57. Lorich, Cody. Helen. 2016. Watercolor \& Marker. West Virginia University School of Theatre \& Dance, Morgantown, WV. Digital Image.

58. West Virginia University Photography. Helen, 2016. Photograph. West Virginia University of Theatre \& Dance, Morgantown, WV. Digital Image.

59. How to put on a Chiton, Roman Fashion, 1000 Atmospharen. 1000atmosphaeren.at.

60. Lorich, Cody. Menelaus. 2016. Watercolor \& Marker. West Virginia University School of Theatre \& Dance, Morgantown, WV. Digital Image.

61. Lorich, Cody. Menelaus, 2016. Photograph. West Virginia University of Theatre \& Dance, Morgantown, WV. Digital Image.

62. Greek Breastplate, Ancient Greek Armor, Ancient Greece. sites.google.com/a/cbmsonline.net/greece-pink.

63. Bad Combover. Holy Taco. 11 Dec. 2008. holytaco.com.

64. Greek key decorative border, Decorating with the Greek Key pattern, The Kellogg Collection. November 2014. kelloggcollection.com.

65. Lorich, Cody. Ms. Brennan Ventilating, 2016. Photograph. West Virginia University of Theatre \& Dance, Morgantown, WV. Digital Image.

66. Lauren Brennan. Finished Menelaus Wig, 2016. Photograph. West Virginia University of Theatre \& Dance, Morgantown, WV. Digital Image.

67. Brennan, Lauren. Ombre dying, 2016. Photograph. West Virginia University of Theatre \& Dance, Morgantown, WV. Digital Image.

68. Lorich, Cody. Poseidon fitting, 2016. Photograph. West Virginia University of Theatre \& Dance, Morgantown, WV. Digital Image. 
69. Lorich, Cody. Students ice dying, 2016. Photograph. West Virginia University of Theatre \& Dance, Morgantown, WV. Digital Image.

70. Brennan, Lauren. Foam Mask Process, 2016. Photograph. West Virginia University of Theatre \& Dance, Morgantown, WV. Digital Image.

71. Brennan, Lauren. Sculpted Mask Process, 2016. Photograph. West Virginia University of Theatre \& Dance, Morgantown, WV. Digital Image.

72. Lorich, Cody. Mask Process, 2016. Photograph. West Virginia University of Theatre \& Dance, Morgantown, WV. Digital Image.

73. West Virginia University Photography. Cast Tableau, 2016. Photograph. West Virginia University of Theatre \& Dance, Morgantown, WV. Digital Image.

74. Lorich, Cody. Chorus wearing masks, 2016. Photograph. West Virginia University of Theatre \& Dance, Morgantown, WV. Digital Image.

75. Lorich, Cody. Chorus without mask, 2016. Photograph. West Virginia University of Theatre \& Dance, Morgantown, WV. Digital Image. 
